Prepared for the U.S. Department of Energy under Contract DE-AC05-76RL01830

\title{
Renewable Energy Opportunities at White Sands Missile Range, New Mexico
}

\author{
WD Chvala \\ WM Warwick \\ AE Solana \\ MR Weimar \\ DR Dixon, Program Manager
}

JC States

September 2008
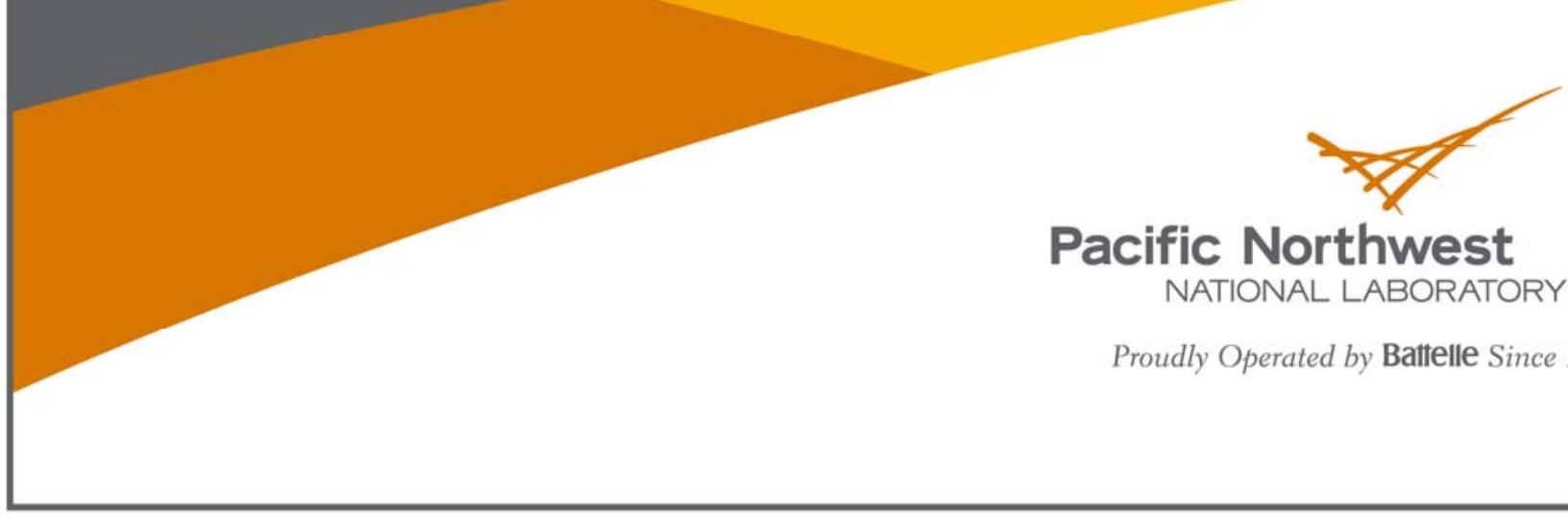

Pacific Northwest

NATIONAL LABORATORY

Proudly Operated by Battelle Since 1965 


\section{DISCLAIMER}

United States Government. Neither the United States Government nor any agency thereof, nor Battelle Memorial Institute, nor any of their employees, makes any warranty, express or implied, or assumes any legal liability or responsibility for the accuracy, completeness, or usefulness of any information, apparatus, product, or process disclosed, or represents that its use would not infringe privately owned rights. Reference herein to any specific commercial product, process, or service by trade name, trademark, manufacturer, or otherwise does not necessarily constitute or imply its endorsement, recommendation, or favoring by the United States Government or any agency thereof, or Battelle Memorial Institute. The views and opinions of authors expressed herein do not necessarily state or reflect those of the United States Government or any agency thereof.

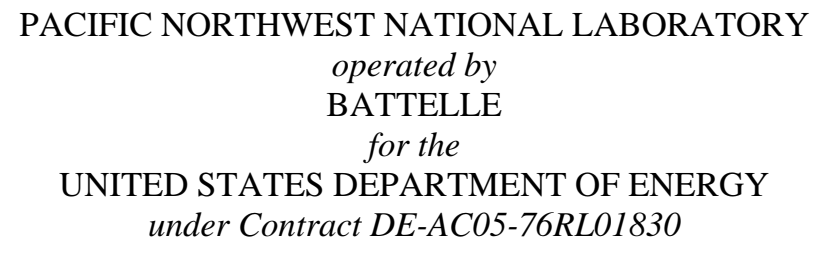

Printed in the United States of America

Available to DOE and DOE contractors from the Office of Scientific and Technical Information,

P.O. Box 62, Oak Ridge, TN 37831-0062;

ph: (865) 576-8401, fax: (865) 576-5728

email: reports@adonis.osti.gov

Available to the public from the National Technical Information Service, U.S. Department of Commerce, 5285 Port Royal Rd., Springfield, VA 22161

ph: (800) 553-6847, fax: (703) 605-6900

email: orders@ntis.fedworld.gov

online ordering: http://www.ntis.gov/ordering.htm

This document was printed on recycled paper.

$(8 / 00)$ 
PNNL-20221

\title{
Renewable Energy Opportunities at White Sands Missile Range, New Mexico
}

\author{
WD Chvala $\quad$ AE Solana JC States \\ WM Warwick MR Weimar \\ DR Dixon, Program Manager
}

September 2008

Prepared for

the U.S. Army Installation Management Command Headquarters

under Contract DE-AC05-76RL01830

Related Services

Pacific Northwest National Laboratory

Richland, Washington 99352 



\section{Executive Summary}

Energy has become an increasingly expensive component of military operations in the United States and abroad. The Department of Defense (DoD) identified renewable resource options and alternatives for domestic facilities in its Renewable Energy Assessment Final Report and associated Implementation Plan in 2005. Based on those results, DoD established a goal of obtaining $25 \%$ of its domestic electricity from renewable sources by 2025. At the time, this was a stretch goal that pushed DoD beyond the renewable mandates in Executive Order 13123, which DoD was already exceeding. Since that time, new renewable mandates and schedules have been established in the Energy Policy Act of 2005 (EPAct) and in Executive Order 13423. In addition, the DoD renewables goal was formalized in the National Defense Authorization Act (NDAA) of 2007. The $110^{\text {th }}$ Congress (January 2007 through January 2009) considered increasing federal renewable energy goals to levels near those adopted by DoD in 2007. This provision was eliminated before passage of The Energy Independence and Security Act of 2007 (EISA). The issue is, however, likely to be reconsidered by Congress in the future.

The Army has numerous compelling reasons to substitute renewable energy for conventional energy procurements at its installations and facilities, including:

$\checkmark$ Reducing energy costs and energy cost volatility,

$\checkmark$ Enhancing supply reliability by utilizing local indigenous generating sources,

$\checkmark$ Increasing resilience and endurance through development of on-site renewable resources,

$\checkmark$ Exposing soldiers to renewable technologies that will be deployed in theater, and

$\checkmark$ Complying with applicable laws and policies.

This document provides an overview of renewable resource potential at White Sands Missile Range (WSMR) based primarily upon analysis of secondary data sources supplemented with limited on-site evaluations. The effort was funded by the U.S. Army Installation Management Command (IMCOM) as follow-on to the 2005 DoD Renewable Energy Assessment. This effort focuses on grid-connected generation of electricity from renewable energy sources and also ground source heat pumps (GSHPs) for heating and cooling buildings, as directed by IMCOM.

This report creates a roadmap for focusing the installation's efforts on realistic projects, moving them from initial assessment through design and financing to implementation. Implementation approaches are recommended for each economically viable technology. This report is a first step, but not the only step, towards meeting WSMR's renewable energy goals.

At the current time there are several renewable technologies that show economic potential at WSMR (see table 1). The two most promising are a waste-to-energy plant and a wind energy project. The geothermal resource shows promise for electricity generation, but confirmation of this resource is necessary and can be very expensive and risky. For GSHPs, a number of technology combinations are not cost effective for any building. At WSMR, GSHPs tend to be more cost effective in administration buildings than in barracks. GSHPs should be considered for new construction if soil conditions prove viable. Other renewable technologies did not prove to be cost effective with current 
conditions and assumptions. Biomass generation will not be economic unless a viable biomass resource becomes available nearby. Solar projects could be cost effective on post if renewable energy credits (RECs) could be sold at a sufficiently high rate. New Mexico utilities have a Renewable Portfolio Standard (RPS) to meet, which encourages utilities to invest in renewable energy projects.

The waste-to-energy projects evaluated at WSMR look promising. The key to these projects is the availability of waste from surrounding communities. WSMR waste alone is inadequate to support an economically viable waste-to-energy plant. A viable plant would need the wastes from at least one of the two neighboring landfills, and this waste must be accompanied by an avoided tipping fee as a contribution to project costs.

A wind energy project at WSMR shows some promise. The current cost of commercial power is close to costs from a wind generation project. The wind resource at the Quartzite Mountain site has been monitored and has demonstrated adequate winds for project consideration. The site needs to undergo further investigation to determine if the site is suitable for construction of a project, how much space is available for turbine installation, and if adequate interconnection and transmission is available.

The geothermal resource shows promise for electricity generation, but confirmation of this resource is necessary and can be very expensive and risky. The resource analysis for the geothermal area at WSMR and Ft. Bliss found high potential for utility grade geothermal electricity production, with the potential for a cost-effective project identified. The economic analysis for geothermal electricity at WSMR relied upon many assumptions regarding the resource potential and the incentives that would be available for geothermal energy. We assumed that assembly of the renewable energy system would meet the exemption requirements for the state sales tax. This assumption would need to be checked carefully with the State of New Mexico. Also, the temperature and gradient resource estimations need to be confirmed with actual well data and further geological studies.

Increasing use of renewable energy makes sense for the Army. The goal of this report is to help Army personnel make sense of renewable energy at WSMR. 
Table 1: Summary of Promising Renewable Energy Projects at White Sands Missile Range

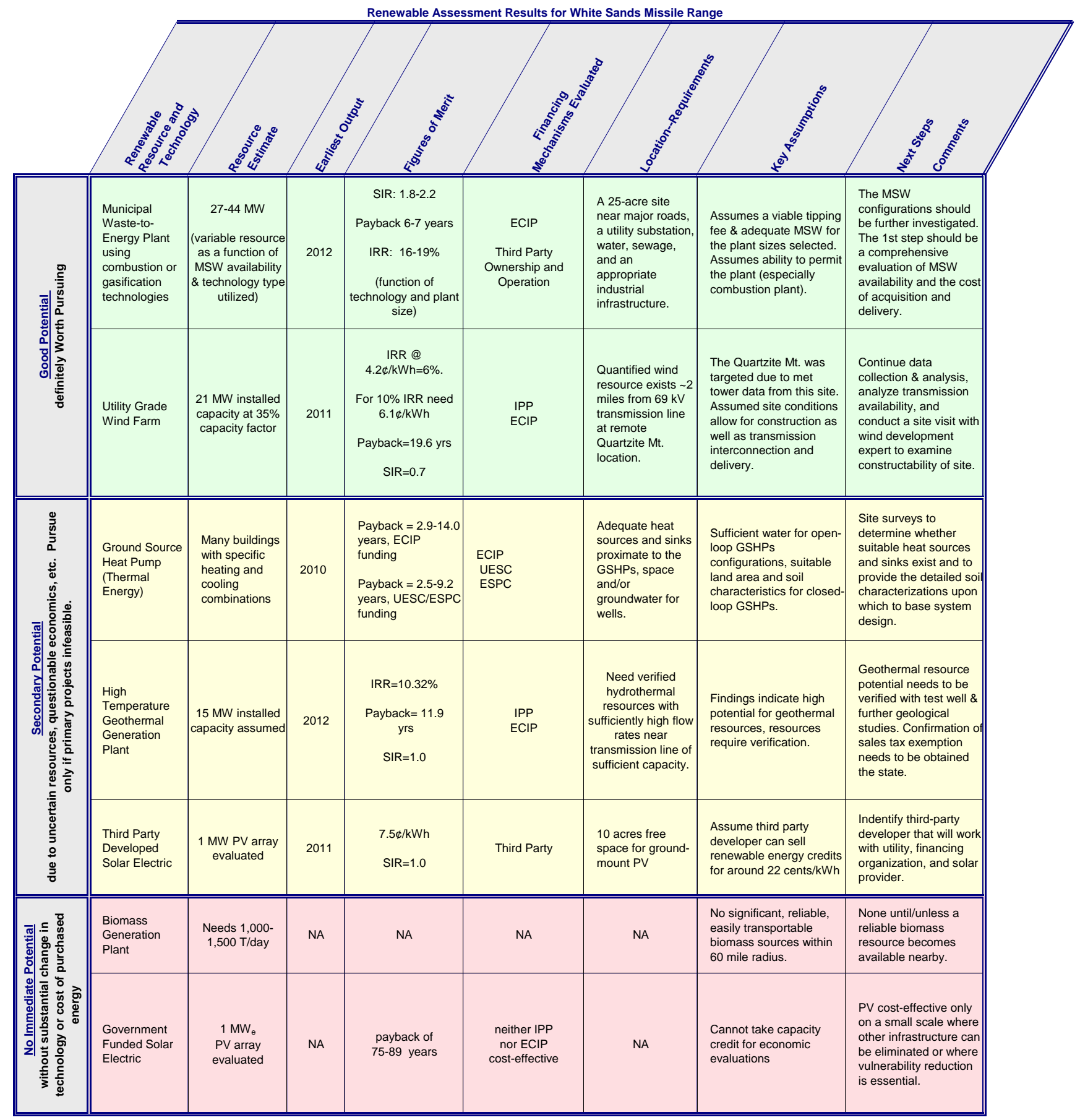

SIR = savings-to-investment ratio

IRR = Internal Rate of Return

ECIP $=$ Energy Conservation Investment Program

IPP $=$ independent power produce

UESC = Utility Energy Services Contract

ESPC $=$ Energy Savings Performance Contract

MSW $=$ municipal solid waste

WTE = waste-to-energy

GSHP $=$ Ground Source Heat Pumps 
Renewable Energy Opportunities at White Sands

Missile Range, New Mexico

Pacific Northwest National Laboratory, Sept 2008 


\section{Table of Contents}

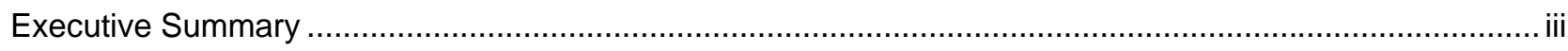

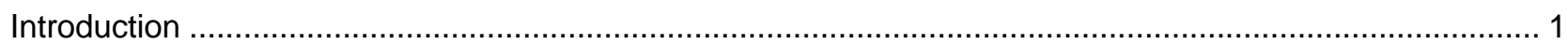

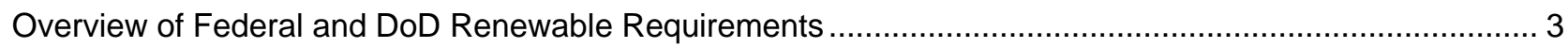

Analysis of Renewable Energy at White Sands Missile Range .......................................................... 5

Approach for Identifying, Analyzing, and Implementing Renewable Energy Projects ...................... 5

Importance of Financing Mechanisms for Project Feasibility................................................... 6

The Political and Economic Environment for Renewables at White Sands Missile Range ............... 7

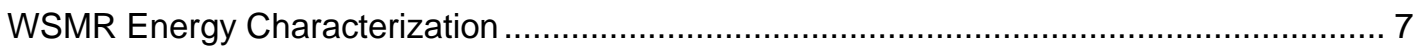

State Incentives for Renewable Project Development................................................... 7

Federal Incentives for Renewable Project Development................................................. 7

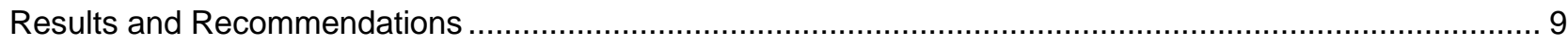

Waste-to-Energy Findings and Recommendations .............................................................. 10

Ground Source Heat Pump Findings and Recommendations.................................................... 11

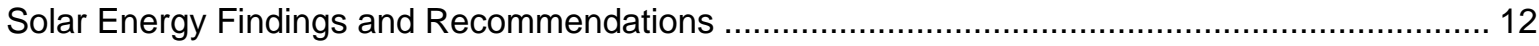

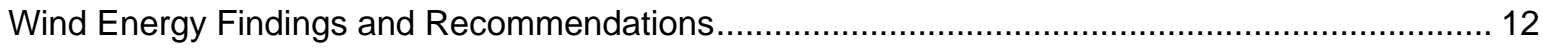

Geothermal Power Plant Findings and Recommendations ................................................ 13

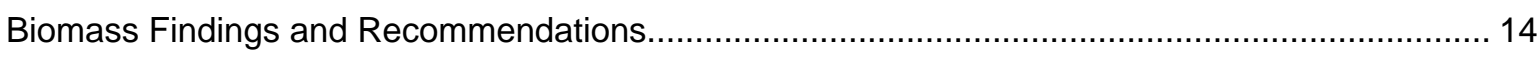

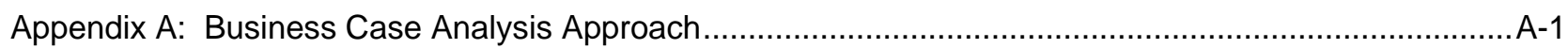

Overall Basis for Project Economic Feasibility .........................................................................

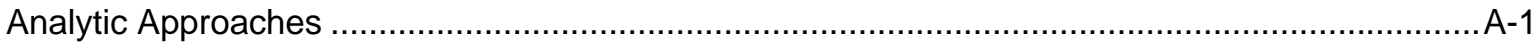

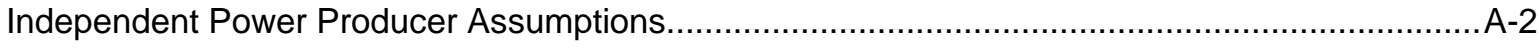

Federal Incentives for Renewable Energy ..........................................................

New Mexico specific incentives and taxes................................................................

Other Independent Power Producer Assumptions ..........................................................

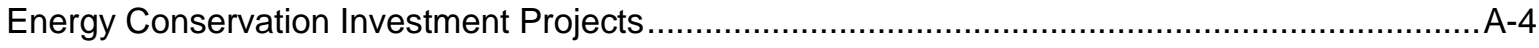

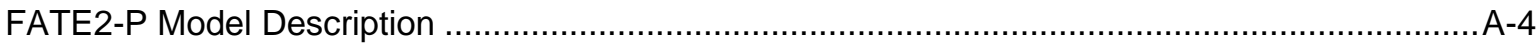

Private Ownership Rate of Return Methodology .....................................................

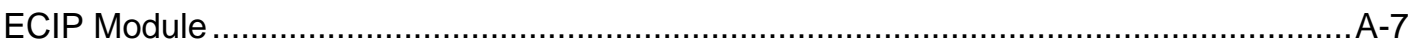

The Federal Energy Decision System (FEDS) Model ….......................................................

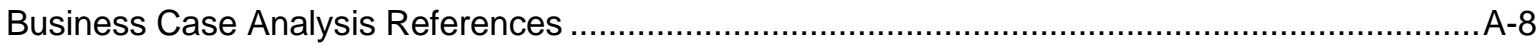

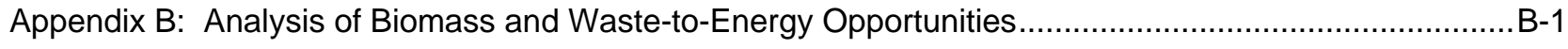

Biomass and Waste-to-Energy Technology ........................................................................

Biomass and Waste-to-Energy Analysis Approach .................................................................

Biomass and Waste Resource Characterization .......................................................................

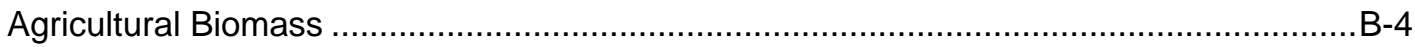




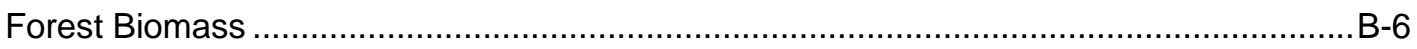

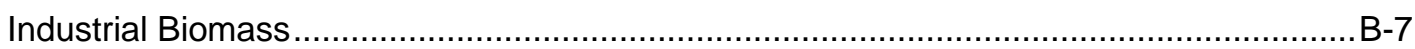

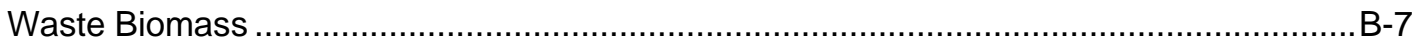

Biomass and Waste-to-Energy: Economic and Other Analysis Parameters ............................... B-9

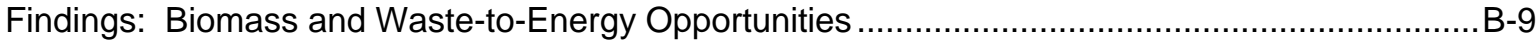

Biomass and Waste-to-Energy: Next steps .......................................................................

Biomass and Waste-to-Energy References............................................................................

Appendix C: Analysis of Geothermal Power Plant Opportunities ...........................................................

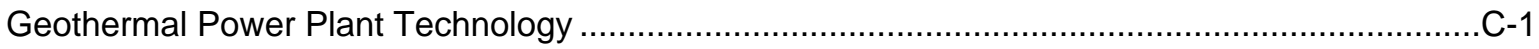

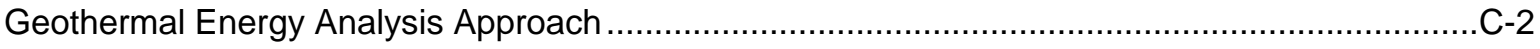

Geothermal Resource Characterization..............................................................................

Geothermal Power Plants: Economic and Other Analysis Parameters ......................................-7

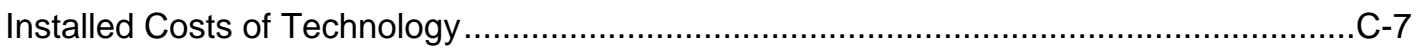

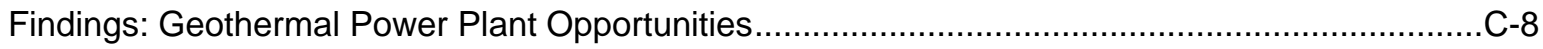

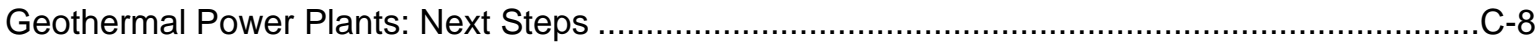

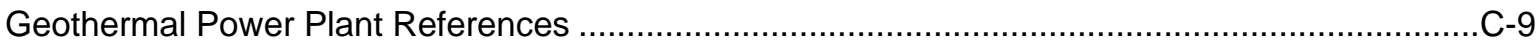

Appendix D: Analysis of Ground Source Heat Pump Opportunities ....................................................

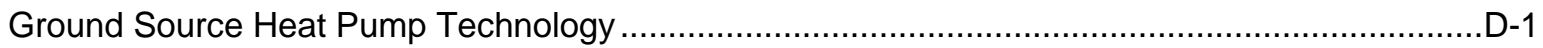

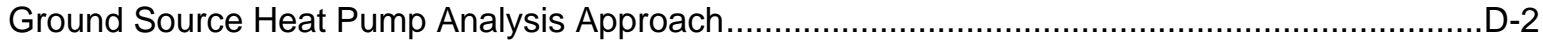

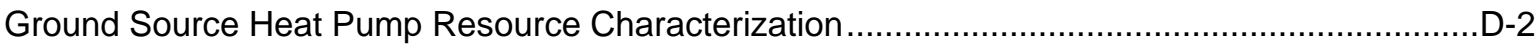

Ground Source Heat Pumps: Economic and Other Analysis Parameters................................... -4

Findings: Ground Source Heat Pumps ..............................................................................

Ground Source Heat Pumps: Next steps ...................................................................................

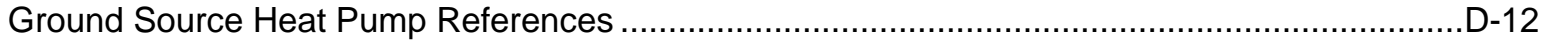

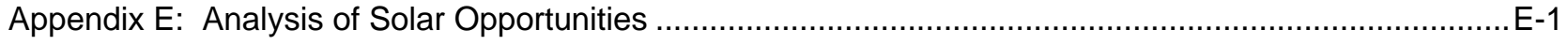

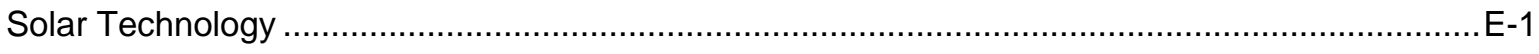

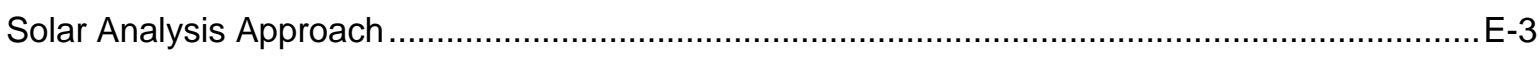

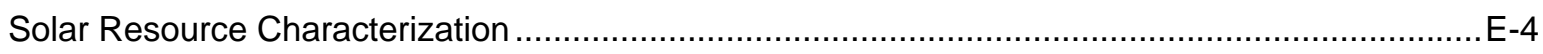

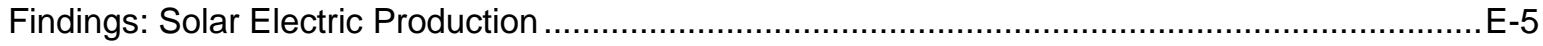

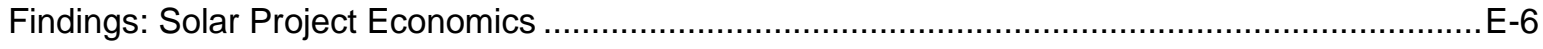

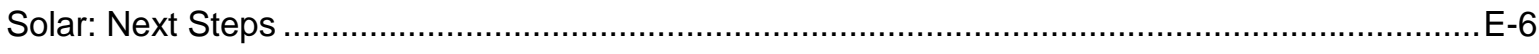

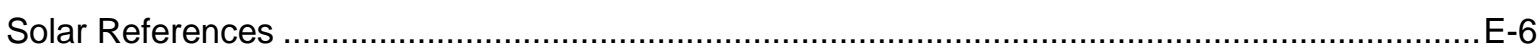

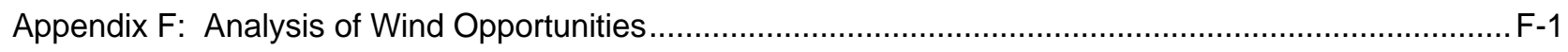

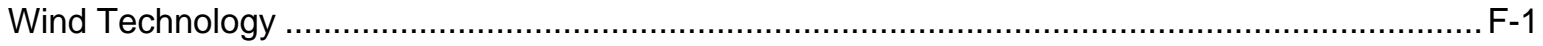

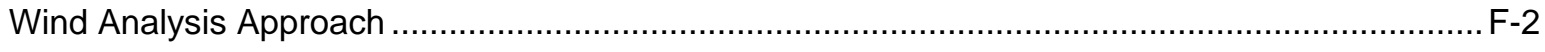

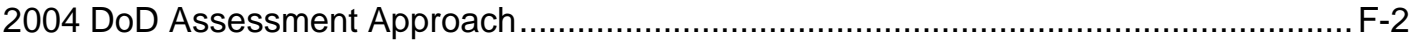

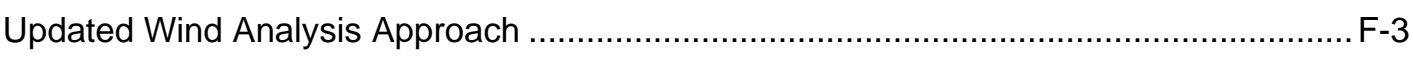

viii Renewable Energy Opportunities at White Sands

Missile Range, New Mexico
Pacific Northwest National Laboratory, Sept 2008 


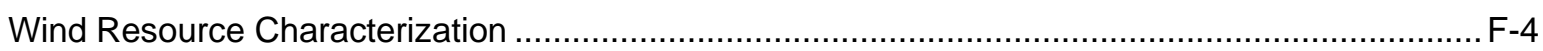

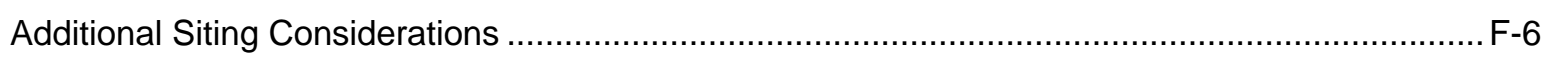

Wind: Economic and Other Analysis Parameters ..................................................................... F-6

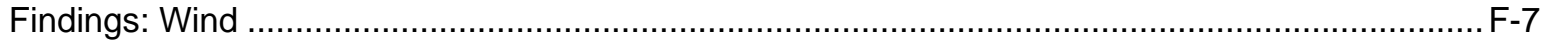

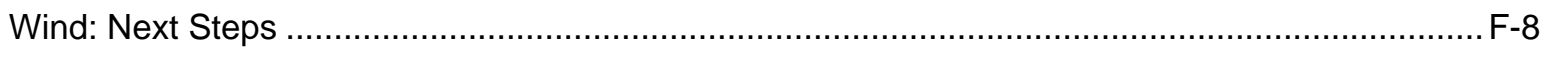

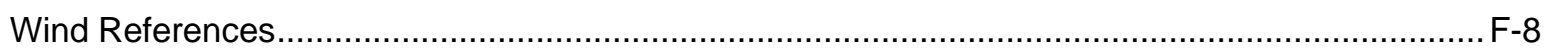




\section{Figures}

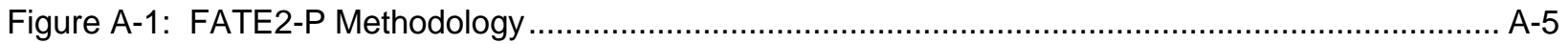
Figure C-1: Geothermal Map in the WSMR/Ft. Bliss Region from the DoD Geothermal Assessment ... C-4 Figure C-2: Geothermal Temperatures at McGregor Range Base Camp from the DoD Geothermal

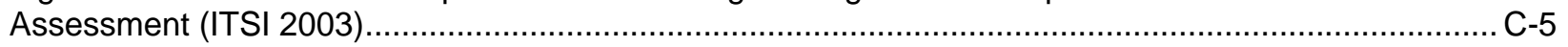

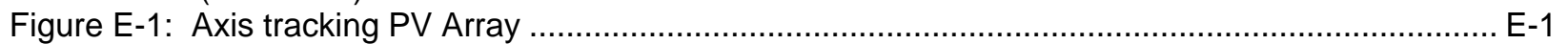

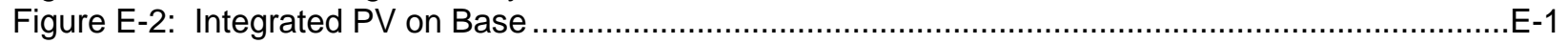

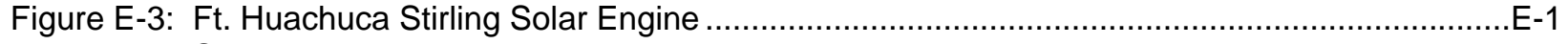

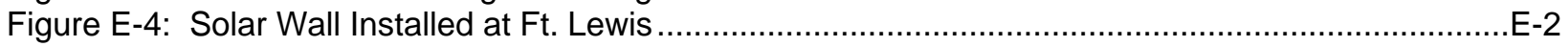

Figure E-5: Daylighting Fixtures at the Yakima Training Center......................................................

Figure E-6: White Sands Missile Range Average Daily Insolation ...............................................E-4

Figure F-1: Initial Location of Met Tower and Potential Wind Developments Area at WSMR (GEC 2004)

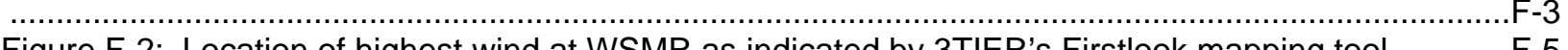

Figure F-2: Location of highest wind at WSMR as indicated by 3TIER's Firstlook mapping tool............F-5

\section{Tables}

Table 1: Summary of Promising Renewable Energy Projects at White Sands Missile Range................... V

Table 2: Legislated Renewable Energy Targets for DoD …............................................................. 3

Table 3: Summary of WSMR Renewable Energy Opportunities ........................................................ 9

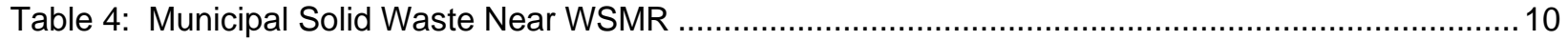

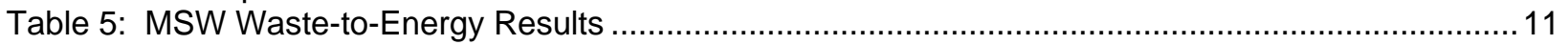

Table A-1: MACRS Depreciation Rates for Renewable Energy Projects ......................................... A-2

Table A-2: Discount Rate Assumptions in the ECIP model .......................................................... A-4

Table B-1: Municipal Solid Waste Near WSMR .......................................................................... B-8

Table B-2: Economic Assumptions, constant \$2007 ................................................................ B-10

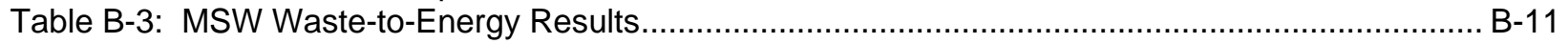

Table C-1: Performance, Cost, and Economic Characteristics ….................................................... C-8

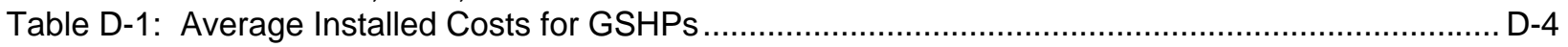

Table D-2: Economic Evaluation of GSHP Opportunities at WSMR. …….................................... D-5

Table D-3: Results for Open-Loop GSHPs at WSMR - ECIP Funding Scenario ............................... D-6

Table D-4: Results for Horizontal Closed-Loop GSHPs at WSMR - ECIP Funding Scenario .............. D-7

Table D-5: Results for Vertical Closed-Loop GSHPs at WSMR — ECIP Funding Scenario .................. D-9

Table D-6: Results for Open-Loop GSHPs at WSMR - Alternative Financing …............................ D-10

Table D-7: Results for Horizontal Closed-Loop GSHPs at WSMR - Alternative Financing (UESC/ESPC)

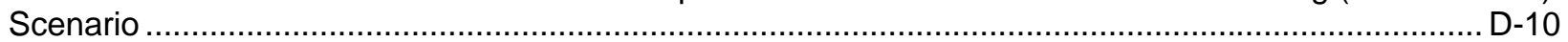

Table D-8: Results for Vertical Closed-Loop GSHPs at WSMR — Alternative Financing (UESC/ESPC)

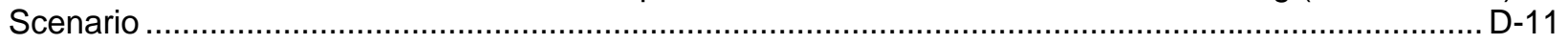

Table E-1: Monthly Averaged Radiation Incident On An Equator-Pointed ........................................ E-4

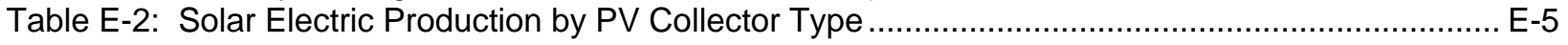

Table F-1: Performance, Cost, and Economic Characteristics .......................................................... 


\section{Introduction}

Pacific Northwest National Laboratory (PNNL) has been directed by the U.S. Army Installation Management Command (IMCOM) to conduct detailed analyses of the potential for electricity generation at selected U.S. Army installations. The goal of the analyses is to identify economically feasible opportunities for generation of electricity from renewables-generation that is significant enough to warrant connection to the grid and/or to contribute in a meaningful way to the aggressive renewable energy goals of the Army and the Department of Defense (DoD).

In 2005, PNNL led a study to identify utility-scale electricity generation opportunities at Department of Defense installations. That study focused on solar, wind, and geothermal. A limited number of attractive large-scale commercial opportunities were identified and their implementation is now being pursued. The study also identified a number of potential smaller opportunities that needed to be investigated further before project implementation decisions could be made.

This analysis of opportunities at White Sands Missile Range (WSMR) is one of a suite of analyses being conducted at Army installations as follow-on to the 2005 study. Its goal is to revisit potential renewable opportunities, updating the analysis for changes in economics, incentives, knowledge about the available renewable resource, and other factors. In addition, IMCOM has directed PNNL to evaluate the potential for biomass, waste-to-energy, and retrofitting heating, ventilation and air conditioning (HVAC) systems in existing buildings with ground source heat pumps (GSHPs). Retrofitting with GSHPs is obviously not an electricity generation opportunity, but it is an opportunity for significant energy savings and replacement of fossil fuels across the DoD. As part of the analysis, IMCOM has directed PNNL to lay out the steps necessary to implement the project opportunities that are identified.

The overall findings of this analysis are summarized in the main body of the report. The business case approach that underlies the analysis of each renewable technology is documented in Appendix A. Appendix B describes the analysis conducted on biomass and waste-to-energy technologies. Appendix C describes the geothermal analysis; Appendix D, the GSHP analysis; Appendix E, the solar analysis; and Appendix F, the wind energy analysis. 
Renewable Energy Opportunities at White Sands

Missile Range, New Mexico

Pacific Northwest National Laboratory, Sept 2008 


\section{Overview of Federal and DoD Renewable Requirements}

The Army needs to satisfy multiple goals and constraints while securing its energy suppliesfocusing upon procurement of the lowest-cost energy that meets high reliability standards and minimum vulnerability to interruption from natural or intentional causes. Overlaid on this challenge is the need to comply with a series of somewhat contradictory statutes and policies, as laid out in Table 2. These include:

$\checkmark$ EPAct Section 203. This law mandates the minimum contribution of renewable energy to an installation's total electricity consumption. The target fractions are; 3\% for FY 2007 through FY 2009, 5\% through FY 2012, and not less than 7.5\% beginning in FY 2013. Recently proposed legislation, Senate Bill 1321, would increase these goals to 10\% by FY 2010 and 15\% by FY 2015. Although the bill has become law as the EISA, the renewable energy provisions were not included in the final version. It is likely this provision will be reintroduced in energy legislation in the next Congress.

$\checkmark$ Executive Order 13423. The Executive Order reiterates the EPAct goals; however it uses a different basis than EPAct for measuring and crediting progress.

$\checkmark$ The National Defense Authorization Act (NDAA). The NDAA codifies DoD's voluntary goal of 25\% of total energy from renewables by 2025, but doesn’t include any interim targets.

Table 2: Legislated Renewable Energy Targets for DoD

\begin{tabular}{||l|c|c|c||}
\hline & EPAct Section 203 & $\begin{array}{c}\text { Executive Order } \\
\mathbf{1 3 4 2 3}\end{array}$ & $\begin{array}{c}\text { National Defense } \\
\text { Authorization Act } \\
\text { (2007) }\end{array}$ \\
\hline \hline Target/Goal & $\begin{array}{c}\text { Increasing targets reaching } \\
7.5 \% \text { renewable content of } \\
\text { electricity consumed }\end{array}$ & $\begin{array}{c}\text { At least 7.5\% of electric } \\
\text { energy from new } \\
\text { renewable energy with } \\
50 \% \text { from new sources } \\
\text { (after 1998) }\end{array}$ & $\begin{array}{c}25 \% \text { of total energy } \\
\text { from Renewable } \\
\text { Energy sources }\end{array}$ \\
\hline Target Dates & 2013 & 2013 & No \\
\hline Mandatory? & Yes & Yes & Yes \\
\hline $\begin{array}{l}\text { Considers thermal } \\
\text { energy "renewable"? }\end{array}$ & No & Yes & No \\
\hline \hline
\end{tabular}

Although DoD would like a single set of requirements and guidelines, that is not the current situation - there are still multiple goals and somewhat conflicting oversight documents. The Department of Energy is responsible for developing guidance for EPAct and EO 13423. The previous Executive Order, EO 13123, had an expansive view of renewable energy. It allowed renewable energy that displaced conventional energy other than electricity to be credited as electricity savings. In other words, thermal energy saved from use of GSHPs was treated as a reduction in electricity from conventional sources. However, the language in EPAct has a narrower definition. It specifies that the reduction must be from “electricity used.” DOE's current interpretation is that renewable energy that is not electricity, such as solar thermal energy, 
daylighting, or GSHPs, cannot be credited towards the EPAct goals. DOE's guidelines for EO compliance allow credit for renewable energy that reduces electricity use from thermal sources; however, it adds a requirement that at least $50 \%$ of renewable energy must come from "new" resources (those put into service after January 1,1999). Congress did not provide a definition of "renewable" in the NDAA language, and DOE is not responsible for establishing DoD or Army policies to achieve the goals in the NDAA. The current Army energy strategy and associated draft renewable policy takes an expansive view of renewables, which encompasses thermal energy from renewable sources. As a result, the Army needs to proceed in a way that makes sense for the Army in a good faith effort to satisfy Congressional, Administration, and Pentagon mandates and directives. The expectation is that the Army will meet the stricter definitions of EPAct on its way to meeting the much higher renewable goals of the NDAA. 


\section{Analysis of Renewable Energy at White Sands Missile Range}

This analysis is follow-on from the 2005 DoD Renewable Energy Assessment. Its goal is to revisit the full suite of renewable alternatives at White Sands Missile Range, updating the analyses to reflect changes in economics, incentives, local knowledge about the renewable resources, and other factors. This study contrasts with the DoD assessment in that the latter focused on "utility scale" renewable generating projects from wind and geothermal resources and solar for on-site use. The current study encompasses the full range of renewable energy options listed in EPAct, primarily focused on uses on site. The most significant additions are assessments for biomass and waste-to-energy (WTE) resources and for use of GSHPs.

\section{Approach for Identifying, Analyzing, and Implementing Renewable Energy Projects}

Renewable energy resources are unlike conventional resources because the "fuel" is essentially free. However, harnessing this free resource requires substantial investment in resource exploration, characterization, and collection; project development; and ongoing maintenance and operation. A renewable resource is like purchasing a new car with a lifetime of fuel as part of the purchase agreement. First costs are much higher, but total cost may be (should be) lower over the long run.

Economic development of renewable energy depends upon:

$\checkmark$ Access to a renewable resource,

$\checkmark$ Development resources, and

$\checkmark$ Financing that is economically attractive and allowed by federal and $\mathrm{DoD}$ regulations.

Each of these is critically important.

Obviously, a renewable resource has to be available and accessible to be developed. The best resources are those with the greatest potential for displacing conventional fuels or power supplies. Development cost, however, is the great equalizer, and a project based upon an excellent resource that is located many miles away may be inferior to a project based upon a lesser resource nearby. For example, an excellent wind resource far from an adequate transmission line may be less attractive than an inferior resource adjacent to a transmission line. Similarly, waste resources that could be used in a central plant may not be economic, even if they are "free," if the transportation, handling, and storage costs are greater than the cost of continued use of conventional heating fuels.

Development costs are relatively comparable for similar size projects. This is why the quality of the resource is so important — namely for the same investment, you get more out of a high quality resource than a lower quality one. But, development costs also include access to transmission capacity for shipping power to users, or alternatively, access to a retail customer. This is a critical difference because power shipped over transmission lines has to compete against the prevailing wholesale price for power from conventional resources. Typically, renewables are not competitive in these markets unless a buyer specifically demands renewable power. On the other hand, if the power can be used on site to displace power purchased from the local utility, it competes against that customer's retail power price or utility rate. Because retail power prices include costs for transmission, distribution, and administrative costs, they are higher than wholesale power prices and make competing renewable projects more attractive economically. 
It is important that economic analyses of renewable energy opportunities use realistic data on avoided energy costs, project costs, and available incentive funds, if any. A common analytic mistake is the use of average cost per $\mathrm{kWh}$ - the so-called "blended" rate. Using the blended rate will lead to inaccurate results when the renewable resource is intermittent (like wind and solar) because intermittent resources cannot be guaranteed to reduce peak demand. Even non-intermittent resources may not result in reduced peak demand because of periodic maintenance shutdowns and unscheduled outages. The economic analyses in this report use only the energy component of the power bill to evaluate intermittent resources. This is admittedly conservative.

Additionally, the installation's utility may impose a stand-by or other fee in the face of a major on site generation project that needs to be reflected in the project's cost calculation. The analyses conducted here make no assumptions regarding standby charges because those are typically assessed on a project-by-project basis.

\section{Importance of Financing Mechanisms for Project Feasibility}

Financing is a critical determinant of development costs because the high first costs are sensitive to financial factors such as incentive payments, tax breaks, and interest rates. Incentive payments and tax breaks reduce first costs, lowering both the overall project cost and interest costs. Because financing is so critical, project economics (payback rates, life-cycle costs, etc.) constitute the best initial screen for project potential. That screen needs to reflect various financing alternatives, which in turn, helps energy managers decide on the best project development approach.

The 2005 DoD Renewable Assessment focused on wind, solar and geothermal power production under the assumption these were the lowest cost and most available on DoD lands. The study was also focused on "utility-scale" projects on the premise that if a good renewable resource exists at a site, it should be developed to its maximum potential. Utility-scale projects far exceed any realistic expectation for appropriated funding so the assessment focused on commercial (third party) development of projects. Besides funding limitations, there are other reasons that these large projects should be implemented by third-party investors - under current DoD philosophy, resource development is not a core DoD mission and should be left to the private sector. In addition, private developers value renewable energy credits (RECs) more highly than the Army does. As a result, letting the developers retain the RECs will reduce the cost of energy to the installation if the developer is selling power from the project to the site.

Private sector developers have to compete in wholesale power markets. As a result, one economic criterion for the DoD study was that projects be competitive with current and projected wholesale power prices. Utility-scale wind, geothermal, biomass, landfill gas, and municipal solid waste projects, under the right conditions, can be (and are currently) competitive.

The DoD study found that "utility-scale" potential for geothermal and wind power production on military installations is rare. It did, however, identify good potential for projects to serve on-site needs, although these still require more site-specific data collection and analysis to develop projects. A similar lack of data forced the DoD assessment to ignore potential for biomass and WTE projects. At the same time, the study revealed factors that make assessing the potential for biomass and WTE more complicated than simply correlating resources on a map with the location of DoD facilities. Specifically, a significant fraction of the costs of biomass and WTE projects is in fuel collection and delivery. If that infrastructure doesn't exist, economic projects are unlikely. For example, crop waste is often cited as a potential renewable fuel. However, farmers typically rotate crops so sources 
will vary over time and across the potential "fuel shed." In addition, farming is notoriously sensitive to the weather, making the quantity of waste highly variable. Without a reliable source of renewable fuel, biomass is neither reliable nor economic. As a result, assessment of biomass and WTE projects needs to be based on an industry and market analysis rather than simplistic resource surveys. This is also the case for waste materials that can be used for "free" fuel. Agricultural wastes such as poultry litter are a nuisance currently and available for "free." However, the cost of transportation fuel has become an issue and plant operators are now being charged hauling fees. Higher fees are likely if demand for these materials increases with development of more projects that rely upon them.

\section{The Political and Economic Environment for Renewables at White Sands Missile Range WSMR Energy Characterization}

WSMR is provided electricity by El Paso Electric (EPE). WSMR consumed a total of 109,230 MWh (12.5 MW) in FY 2007. WSMR is a summer-peaking facility, with its peak consumption in August of 2007 (13.2 MW peak). The total electricity bill in FY 2007 was $\$ 8.2 \mathrm{M}$, for a total average rate

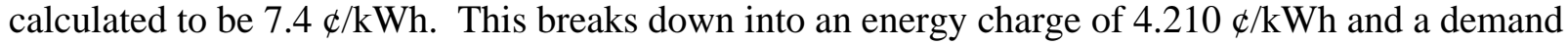
charge of $\$ 19.00$ per $\mathrm{kW}$.

\section{State Incentives for Renewable Project Development}

WSMR opportunities evaluated in this report lie exclusively in New Mexico. New Mexico incentives include a renewable energy tax production tax credit; a gross receipts tax exemption for solar; a sales tax exemption for solar, biomass, wind and geothermal; and a renewable energy portfolio standard (RPS).

The NM renewable energy tax credit is capped at 400,000 MWh annually for wind and biomass and 200,000 MWh annually for solar. There is an annual cap of 2,000,000 MWh for the state, so one needs to carefully consider whether there is any production tax credit capacity available before committing to a project that requires the production tax credit to be included to be feasible. The production tax credit applies up to the cap at 1\$ per kWh for biomass and wind (DSIRE 2007c).

The RPS in time may give opportunities for all types of renewable energy production in New Mexico. The law states that investor owned utilities (IOUs) will be required to have $20 \%$ of their electricity coming from renewable energy. Renewable energy types include solar electric, wind, biomass and geothermal. There doesn't appear to be any interim step requirements in meeting the $20 \%$ total, but there are requirements by type of renewable. Solar has a $4 \%$ set aside; wind, $4 \%$; geothermal 2\%; and distributed renewable energy types $0.6 \%$ of total sales (DSIRE 2007c). For further details on states incentives and references, see Appendix A.

\section{Federal Incentives for Renewable Project Development}

Federal incentives for renewable energy include investment tax credits for corporations, significantly accelerated depreciation of equipment, and production tax credits. A 30\% tax credit is available for photovoltaic projects, and $10 \%$ for geothermal electricity projects. The credits may be taken on equipment placed in service prior to December 2008. There are no incentive limits for solar and geothermal electric projects. Wind is not eligible for the business energy tax credit. The tax basis for depreciation must be reduced by the amount of any federal subsidy used in the financing of the eligible equipment. 
Depreciation for most renewable energy equipment qualifies for significantly accelerated depreciation. For solar, wind and geothermal, the modified acceleration cost recovery system (MACRS) provides for 5-year recovery of the cost of equipment. The 5-year recovery period doesn't apply to biomass or WTE equipment.

The renewable energy production tax credit (PTC), originally established in 1992, provides a tax credit for each kilowatt-hour of electricity produced. The PTC is $2.0 \AA / \mathrm{kWh}$ for wind, geothermal, and closed-loop biomass. The PTC is $1.0 \mathrm{f} / \mathrm{kWh}$ for electricity produced from open-loop biomass and municipal solid waste resources. The credit can be taken for 10 years from the time the equipment is placed in service.

Solar has historically been eligible for a $10 \%$ investment tax credit. It was also briefly eligible for the PTC starting with the 2004 renewal and lasting through 2005. Starting in 2006, the investment tax credit for solar increased to 30\% of eligible system costs (with a $\$ 2000$ cap for residential systems). The higher solar investment tax credit expires after December 31, 2008, although the 10\% credit will remain in place.

Available tax incentives reduce the first-year costs of qualified renewable projects. The lower first cost also reduces the amount of money that may be borrowed to develop a project and thus, the associated interest and carrying costs. The combination reduces the delivered cost of power if developed by a private party with a tax obligation. Government-owned projects do not benefit from tax-based incentives.

The economic analyses in this report used two perspectives: ECIP and third-party financing. Under the latter arrangement, power is sold through a contract that is commonly called a power purchase agreement or PPA. All of the PPA analyses conducted in this report assume that the PTC and other tax credits will be available when the equipment is placed in service. 


\section{Results and Recommendations}

A summary of analysis results is presented in Table 3, broken down into economically viable (green), less favorable (amber), or nonviable (red) projects. The underlying analyses and recommendations for each of these technologies and potential projects are provided in the following subsections.

Table 3: Summary of WSMR Renewable Energy Opportunities

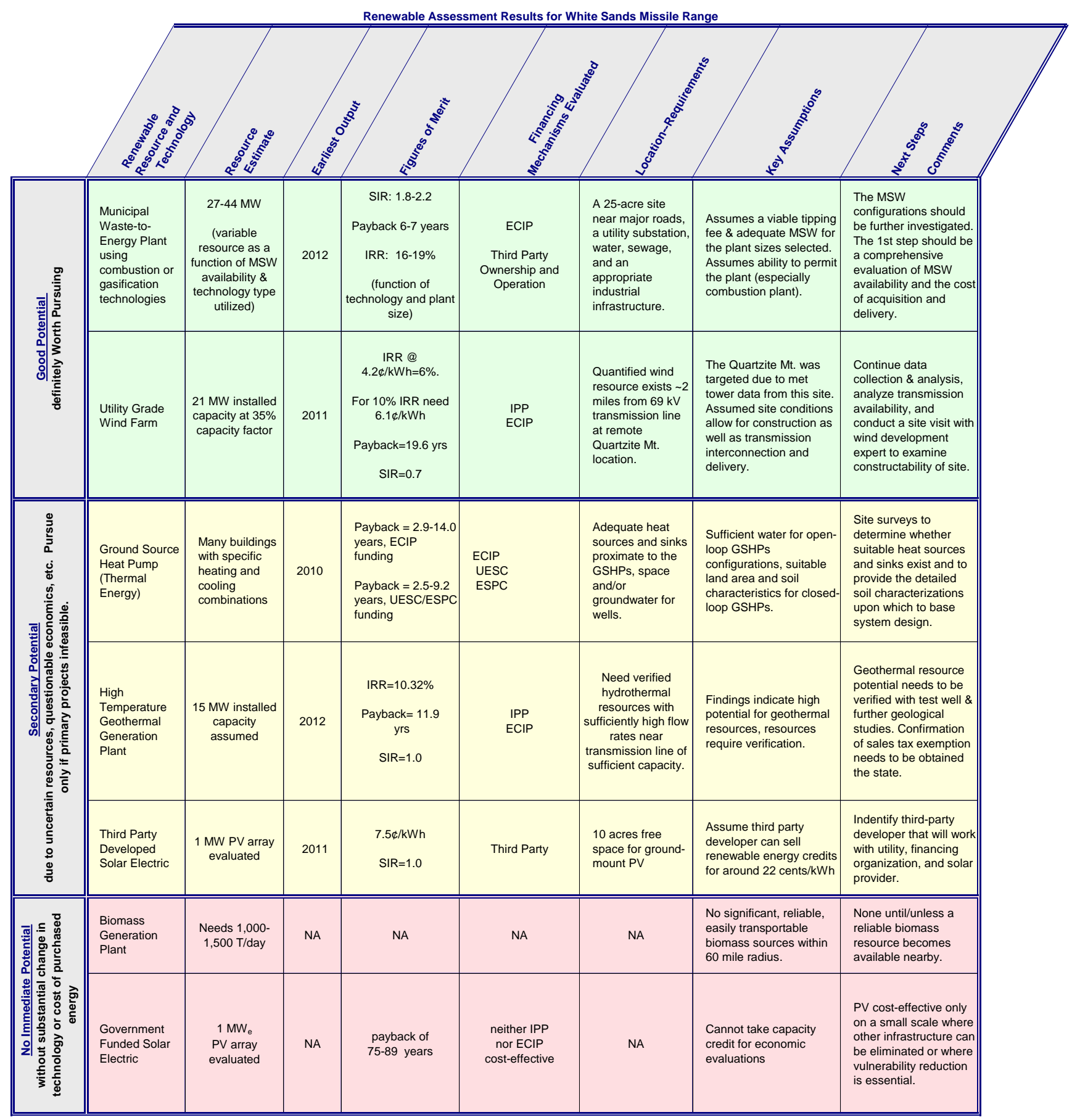


SIR = savings-to-investment ratio

IRR = Internal Rate of Return

ECIP $=$ Energy Conservation Investment Program

IPP = independent power producer

UESC = Utility Energy Services Contract
ESPC $=$ Energy Savings Performance Contract

MSW = municipal solid waste

WTE = waste-to-energy

GSHP $=$ Ground Source Heat Pumps

\section{Waste-to-Energy Findings and Recommendations}

Electricity generation using municipal solid waste (MSW) is an established power generation technology. Growth has been limited because of public and environmental concerns about combustion byproducts. Technologies that gasify materials thermally or with a plasma arc are available, but they are newer to the market and more expensive. Generation using wastes appears to be feasible across a range of potential project sizes and energy conversion technologies at WSMR. The economics of these prospective projects are sensitive to plant size and the availability and price of delivered MSW. There are several options to consider when using MSW for energy production: WSMR-generated waste plus landfill waste from any of two sites would be sufficient for electricity generation. There were no economic projects based solely on WSRM waste because of size (see Table 4 below). Nevertheless, a smaller project may have merit for other reasons, such as meeting energy security and/or waste reduction goals. Smaller projects would be more expensive and may use different technologies than considered in this report.

The combinations that are cost effective are presented in Table 5. Each of these options presented can use combustion or gasification. Project economics will depend on the availability and price of waste, and actual plant size, capital costs, and operating costs. These scenarios show that a number of options are available to WSMR. Combustion of WSMR waste with Amador Transfer Station waste is the most economical, but not significantly so over the other options. Other options may be more desirable to reduce air emissions, generate more power, or for other reasons, and so should still be considered. Detailed results are provided in Appendix B.

Table 4: Municipal Solid Waste Near WSMR

\begin{tabular}{|l|l|c|r|r||}
\hline \multicolumn{1}{|c|}{ Site } & \multicolumn{1}{|c|}{ Collection Location } & $\begin{array}{c}\text { Miles } \\
\text { from } \\
\text { WSMR }\end{array}$ & $\begin{array}{c}\text { Tipping } \\
\text { Fee (\$) }\end{array}$ & $\begin{array}{c}\text { Available } \\
\text { MSW } \\
\text { (tons/year) }\end{array}$ \\
\hline \hline White Sands Missile Range & White Sands Missile Range & 0 & $\$ 22$ & 1,247 \\
\hline Amador Transfer Station & Las Cruces, NM & 20 & $\$ 30.70$ & 240,240 \\
\hline Corralitos Landfill & Las Cruces, NM & 35 & $\$ 24.80$ & 300,000 \\
\hline & \multicolumn{3}{|c|}{ TOTAL AVAILABLE } & $\mathbf{3 0 1 , 2 4 7}$ \\
\hline
\end{tabular}


Table 5: MSW Waste-to-Energy Results

\begin{tabular}{|c|c|c|c|c|}
\hline Waste Source(s) & $\begin{array}{c}\text { Amador } \\
\text { Transfer } \\
\text { Station } \\
\end{array}$ & $\begin{array}{c}\text { Corralitos } \\
\text { Transfer Station }\end{array}$ & $\begin{array}{l}\text { Amador } \\
\text { Transfer } \\
\text { Station } \\
\end{array}$ & $\begin{array}{l}\text { Corralitos } \\
\text { Landfill }\end{array}$ \\
\hline Technology & Combustion & Combustion & Gasification & Gasification \\
\hline Plant Size & $26.6 \mathrm{MW}$ & $33.2 \mathrm{MW}$ & $35.2 \mathrm{MW}$ & $43.9 \mathrm{MW}$ \\
\hline Feedstock Amount & 241,487 tons/yr & 301,247 tons/yr & 241,487 tons/yr & 301,247 tons/yr \\
\hline Total Plant Cost & $\$ 2893.0 / \mathrm{kW}$ & $\$ 2767.9 / \mathrm{kW}$ & $\$ 2958.0 / \mathrm{kW}$ & $\$ 2830.1 / \mathrm{kW}$ \\
\hline Capital Cost & $\$ 2893.0 / \mathrm{kW}$ & $\$ 2767.9 / \mathrm{kW}$ & $\$ 2958.0 / \mathrm{kW}$ & $\$ 2830.1 / \mathrm{kW}$ \\
\hline Sales Tax & $\$ 0.0 / \mathrm{kW}$ & $\$ 0.0 / \mathrm{kW}$ & $\$ 0.0 / \mathrm{kW}$ & $\$ 0.0 / \mathrm{kW}$ \\
\hline Fixed O\&M Cost & $\$ 92.1 / \mathrm{kW}$ & $\$ 88.8 / \mathrm{kW}$ & $\$ 120.3 / \mathrm{kW}$ & $\$ 103.4 / \mathrm{kW}$ \\
\hline Variable O\&M Cost & $-1.8 \$ / k W h$ & $-1.0 \$ / \mathrm{kWh}$ & $-1.7 \$ / \mathrm{kWh}$ & $-1.1 థ / \mathrm{kWh}$ \\
\hline Feedstock Cost & $-\$ 24.79 /$ ton & $-\$ 18.61 /$ ton & $-\$ 24.79 /$ ton & $-\$ 18.61 /$ ton \\
\hline SIR & 2.2 & 2.1 & 1.8 & 1.9 \\
\hline Simple Payback & 6.0 years & 6.4 years & 7.1 years & 6.9 years \\
\hline Internal Rate of Return (IRR), No Financing & $18.58 \%$ & $17.85 \%$ & $16.21 \%$ & $16.68 \%$ \\
\hline
\end{tabular}

\section{Ground Source Heat Pump Findings and Recommendations}

We evaluated the cost effectiveness of retrofitting existing HVAC systems with GSHPs across the range of buildings at WSMR. Detailed results are provided in Appendix D.

At WSMR, GSHPs tend to be more cost effective in administration buildings than in barracks. Using ECIP funding, large buildings and old buildings are much more likely to be cost effective for openloop GSHP retrofits. Groundwater is relatively deep at WSMR, so drilling costs are high and result in fewer viable projects. Replacing chillers and air handling units with horizontal GSHPs is the most cost-effective option for this configuration, especially in small buildings and regardless of the building vintage. Vertical loops are much more expensive than horizontal loops because of the high cost of drilling compared to the cost of trenching. Therefore, there are many fewer cost-effective options here, and the paybacks are longer. Small buildings are the only cost-effective option, and building vintage is still only a minor factor in cost effectiveness.

Only large barracks can cost effectively have HVAC systems replaced with open-loop GSHPs if the project is financed. Only small buildings with chillers and air handling units are cost effective with alternatively financed horizontal GSHPs, regardless of vintage or building type. However, older buildings tend to be slightly less cost effective than other vintages, while admin facilities tend to be slightly more cost effective than barracks. With alternative financing, only small admin facilities with chillers and air handling units are cost-effective options for vertical closed-loop GSHPs. Older facilities tend to be slightly less cost effective, but all vintages are viable options. 
WSMR needs to determine whether water for open-loop systems is available, and if so, if it is environmentally acceptable to use it for GSHP development. WSMR's current building stock then needs to be compared to the building types listed above, and matched to the cost-effective technology combinations. Where there are similarities, detailed building and surrounding land area information should be collected to pursue project viability.

In addition, GSHPs should always be considered for new construction; retrofit GSHP installations (analyzed here) are more expensive. When a new site is being excavated, test the soil to determine site-specific conductivity and other characteristics to see if a GSHP is a good choice for the new building.

\section{Solar Energy Findings and Recommendations}

White Sands Missile Range has an abundant solar energy resource, although project capital costs and current electric rates are not showing these to be cost effective at this time. With current prices, ground mounted PV did not prove economic. Ground mounted fixed-grid PV had a 0.2 SIR and a 89 year simple payback. In fact, to get a positive net-present-value, the system would have to charge $33.4 \mathrm{\$} / \mathrm{kWh}$. The axis-tracking PV system did only slightly better (as a result of its better capacity factor) with a 0.2 SIR and a 75-year simple payback, producing $29.2 \mathrm{cent} / \mathrm{kWh}$ power. See Appendix E for analysis details.

In addition to ground-mounted PV technology, building-integrated PV can also be developed by a third party to take advantage of government incentives. There is some precedence within the Department of Defense for leasing rooftop space for development of solar projects. Building integrated PV products would be especially attractive if available land is constrained. Looking for applicable roof space using satellite imagery shows six buildings with 172,000 square feet of roof area that could host PV arrays. WSMR could install $0.5 \mathrm{MW}_{\text {peak }}$ of roof-integrated PV, which would produce approximately $930 \mathrm{MWh}_{\text {electric }}$ annually.

WSMR should continue to monitor the market conditions affecting solar energy. Advances in PV technology are expected to produce cheaper solar cells, although rising demand may negate some of these advances. Rising energy rates may do the most to tip the scales in favor of solar electric. The most important factor in making solar electric work at a federal installation is identifying key partners - either a private developer, a utility, or both - which can provide funding, capture tax incentives, purchase/market renewable energy credits (RECS), enter into power purchase agreements (PPAs), etc. For example, Fort Carson installed a 2-MW tracking PV array, with funding from a private developer who sold RECs for $22 \mathrm{\$} / \mathrm{kWh}$. The market for RECs varies over time and by region, so it is not possible to know the exact value of RECs for solar PV at WSMR. However, if WSMR could find a private developer that could sell RECs at $22 \$ / \mathrm{kWh}$, the project could lock in electric power production at $7.5 \mathrm{\$} / \mathrm{kWh}$ for 25 years. This could be an attractive project for WSMR.

\section{Wind Energy Findings and Recommendations}

Wind generation shows great promise for WSMR. It makes economic sense to further investigate and pursue a wind generation project on post at this time because the current cost of commercial power from El Paso Electric under the current contract structure is very close to costs for a wind generation project. If a contract to sell the RECs could be obtained for a minimum of $2 \mathbb{6} / \mathrm{kWh}$, it 
could close the gap between electric current rates and the costs for a wind project. Future electric rates are likely to be higher than costs from a wind generation project.

The wind resource at the Quartzite Mountain site has been monitored and has demonstrated adequate winds for project consideration. Utilizing the met tower wind speed (7.0 at $40 \mathrm{~m}$ ), a commercial energy cost of $6.1 \mathrm{\$} / \mathrm{kWh}$ would be required to provide a 10\% IRR (the minimum IRR required to attract wind developers). Compared to the avoided energy cost of $4.2 \mathrm{\$} / \mathrm{kWh}$, the IRR is $6.2 \%$. ECIP projects require an SIR of 1.25. When using $4.2 \mathrm{\$} / \mathrm{kWh}$, the SIR is 0.7 and the payback is 19.6 years.

To verify the potential for a wind project, the site needs to undergo further investigation to determine if the site is suitable for construction of a project, how much space is available for turbine installation, and if adequate interconnection and transmission is available.

WSMR may want to consider the possibility of a partnership with Ft. Bliss to pursue a larger wind project together on Ft. Bliss property to achieve cost saving through economies of scale for a larger project.

\section{Geothermal Power Plant Findings and Recommendations}

The geothermal resource shows promise for electricity generation, but confirmation of this resource is necessary and can be very expensive and risky. The resource analysis for the geothermal area at WSMR and Ft. Bliss found high potential for utility grade geothermal electricity production, with the potential for a cost-effective project identified. The economic analysis for geothermal electricity at WSMR relied upon many assumptions. The resource estimations need to be confirmed with actual well data and further geological studies.

The resource analysis for WSMR found high potential for utility grade geothermal electricity production, with the potential for a cost-effective project identified. The ECIP analysis based upon electricity valued at $7.4 \$ / \mathrm{kWh}$ yielded a payback period of 10.32 years, with an SIR of 1.0. The electricity value of $7.4 \mathrm{\$} / \mathrm{kWh}$ yielded a sufficiently high rate to be considered by an IPP (minimum IRR for IPP to be interested). See Appendix $C$ for details of the analysis and the findings.

The economic analysis for geothermal electricity relied upon many assumptions. The resource data for this assessment is based on the most optimistic well temperature and temperature gradient found at Ft. Bliss from the previous DoD geothermal study. Ft. Bliss and WSMR geothermal resources were considered to be the same for the purposes of this assessment. Further geological studies including the drilling of test wells would need to accurately determine the geothermal resource. The biggest factor in the capital cost is the number of expensive wells required to produce adequate hot water and steam resources at sufficient flow rates. The resource estimations need to be confirmed with actual well data and further geological studies. We also assumed that assembly of the renewable energy system would meet the exemption requirements for the state sales tax. This assumption would need to be checked carefully with the State of New Mexico.

Because the geothermal resource proximate to WSMR is high, further action that should be taken to determine the realities of the geothermal resource potential. Further exploration of the Hueco Tanks/McGregor Range geothermal system at Ft. Bliss, along with other potential areas identified on WSMR property, is warranted. 


\section{Biomass Findings and Recommendations}

There are not any feasible biomass-to-electricity projects on Post. The availability of forest thinnings and logging slash, mill residue, other industrial waste, landfill gas, and wastewater treatment plant sludge is inadequate to consider a biomass generation project. Other potentially available biomass fuels, including crop residue, animal waste, and dedicated biomass crops could not support economic electricity generation. See Appendix B for more details. 


\section{APPENDIX A}

\section{Business Case Analysis Approach}


Renewable Energy Opportunities at White Sands

Missile Range, New Mexico

Pacific Northwest National Laboratory, Sept 2008 


\section{Appendix A: Business Case Analysis Approach}

\section{Overall Basis for Project Economic Feasibility}

The renewable projects considered in this analysis need to compare favorably against the future commercial price of electricity to be purchased by the White Sands Missile Range (WSMR) to be economically feasible. White Sands purchases its electricity from El Paso Electric. White Sands has a simple electricity rate with a demand charge of $\$ 19.00 / \mathrm{kW}$ with a minimum demand of $6 \mathrm{MW}$. The variable rate is $\$ 0.04219 / \mathrm{kWh}$. The energy component of $4.2 \mathrm{\$} / \mathrm{kWh}$ was used for as the avoided rate for both solar and wind while the average rate of $7.4 \mathrm{\$} / \mathrm{kWh}$ was used for waste-toenergy and geothermal.

All but one of the analyses was conducted using the Financial Analysis Tool for Electric Energy Projects financial analysis model (FATE2-P), described later in this appendix. The analysis for ground source heat pumps was conducted using the Federal Energy Decision Screen (FEDS) model, also described in this appendix.

\section{Analytic Approaches}

In assessing the economic feasibility of renewable energy projects at WSMR, PNNL generally evaluated two business case alternatives, (1) investment by an independent power producer (IPP), and (2) Energy Conservation Investment Project (ECIP) funding. These two funding sources have the best returns on federal investments among the available alternatives. Two other alternatives were examined when conditions were also favorable, (3) the utility energy services contract (UESC), and (4) the energy saving performance contract (ESPC).

Under an IPP scenario, an independent power producer will generally fund, construct, and operate a renewable energy facility, selling power into the competitive marketplace and/or directly to the site that hosts the energy project. This scenario is generally economic when the third-party investor can take advantage of substantial federal and state incentives. The incentives depend on the type of renewable energy and may include production tax credits, investment tax credits, substantially accelerated tax depreciation of assets, reductions in sales taxes, and exemption from property tax.

The Energy Conservation Investment Program is one standard DoD approach for making energy efficiency and renewable energy investments using federally appropriated funding. ECIP investment awards are made based upon savings to investment ratio (SIR) and simple payback (SPB) criteria. ECIP funding is limited, and is awarded on a competitive basis within the Army-only the most economic projects can be assured funding. The approach used in the analyses follows the federal life cycle cost (LCC) methodology and procedures in 10 CFR, Part 436, Subpart A. The LCC calculations are based on the Federal Energy Management Program (FEMP) discount rates and energy price escalation rates updated on April 1, 2007.

The utility energy services contract and the energy saving performance contract are very similar approaches, where a third party invests in an energy project on the federal facility in return for a share of the energy savings that result. The major difference is that under an UESC, the third party is a utility-generally the utility providing energy to the federal facility. Under ESPC, the investment party is a non-utility, generally an engineering firm that specializes in energy projects. Under UESC and ESPC, the third party must be repaid out of each year's operational dollars, and the investment must be repaid within the lifetime of the asset. Generally, UESC is more viable than ESPC because 
utilities can obtain capital less expensively than can the ESPC contractor. But not all utilities fund UESC projects and the types of projects funded may be limited, opening the door for ESPC. The UESC/ESPC cannot generally capture depreciation or tax incentives that would be afforded an independent power producer.

\section{Independent Power Producer Assumptions}

In addition to capital and operating costs, project feasibility for the independent power producer is dependent on federal and state tax incentives, interest rates, inflation rates, and required rates of return discussed in the following sections.

\section{Federal Incentives for Renewable Energy}

Federal incentives for renewable energy include investment tax credits for corporations, significantly accelerated depreciation of equipment and production tax credits. Combining the incentives with attractive market prices can, in certain cases, lead to feasible renewable energy projects.

\section{Tax Credits}

A 30\% business energy tax credit is available for photovoltaic projects; while geothermal and biomass electricity generation projects qualify for a $10 \%$ investment tax credit. The credits may be taken on equipment placed in service prior to December 2008 (JCT 2007). There are no incentive limits for solar and geothermal electric. Wind is NOT eligible for the business energy tax credit. The tax basis for depreciation must be reduced by the amount of any federal subsidy used in the financing of the eligible equipment (26 USC $\S 48$ ). The basis of the facility is eligible for $50 \%$ of the total energy tax credit taken (JCT 2007).

\section{Depreciation}

Most renewable energy equipment qualifies for significantly accelerated depreciation using the modified accelerated cost recovery system (MACRS). According to 168(e)(3)(B)(vi) most renewable energy production facilities would qualify for 5-year accelerated depreciation (US Treasury 2007) .

Table A-1 provides the depreciation rates used in the model for 5 year property. They reflect the use of the half-year convention. The basis is reduced by $50 \%$ of any energy investment tax taken (JCT 2007).

Table A-1: MACRS Depreciation Rates for Renewable Energy Projects

\begin{tabular}{|c|c|c|c|c|c|}
\hline Year 1 & Year 2 & Year 3 & Year 4 & Year 5 & Year 6 \\
\hline $60 \%$ & $16 \%$ & $9.6 \%$ & $5.76 \%$ & $5.76 \%$ & $2.88 \%$ \\
\hline
\end{tabular}

\section{Production Tax Credits}

The renewable energy production tax credit (PTC) provides a per-kWh-produced tax credit for electricity generated. The PTC is $2.0 \$ / \mathrm{kWh}$ in 2008 for wind, geothermal, and closed-loop biomass and can be taken for 10 years. The PTC is $1.0 \mathrm{\$} / \mathrm{kWh}$ for electricity produced from open-loop biomass, municipal solid waste resources and can be taken for 5 years. Solar electricity generation has been excluded for equipment placed in service after December 2005 (H.R. 6111, 2006). The 
PTC has been allowed to lapse and then been renewed several times. The PTC is currently set to expire at the end of 2008 (DSIRE 2007a). All of the analysis assumes it will be available when the equipment is placed in service.

\section{New Mexico specific incentives and taxes}

White Sands Missile Range is located in New Mexico. New Mexico incentives include a renewable energy tax production tax credit, a gross receipts tax exemption for solar, a sales tax exemption for solar, biomass, wind and geothermal and a renewable energy portfolio standard (RPS) (DSIRE 2007b).

The renewable energy tax credit is capped at 400,000 MWh annually for wind and biomass and 200,000 MWh annually for solar. There is an annual cap of 2,000,000 MWh for the state, so one needs to carefully consider whether there is any production tax credit capacity available before committing to a project that requires the production tax credit to be included to be feasible. The production tax credit applies up to the cap at $1.0 \mathrm{f} / \mathrm{kWh}$ for biomass and wind.

For the sales tax exemption, we are assuming that the assembly of the renewable energy system would meet the exemption requirements. This assumption would need to be checked carefully with the State of New Mexico.

The RPS in time may give opportunities for all types of renewable energy production in New Mexico. The law states that investor owned utilities (IOUs) will be required to have $20 \%$ of their electricity coming from renewable energy. Renewable energy types include solar electric, wind, biomass and geothermal. There doesn't appear to be any interim step requirements in meeting the $20 \%$ total but there are requirements by type of renewable. Solar has a $4 \%$ set aside; wind $4 \%$; geothermal $2 \%$; and distributed renewable energy types $0.6 \%$ of total sales.

The New Mexico property tax rates for White Sands wind and biomass was assumed to be $1 \%$ for on federal property rates (CTR-Otero 2007; CTR-Dona Ana 2007).

\section{Other Independent Power Producer Assumptions}

The minimum after-tax internal rate of return used in the analysis of IPP opportunities was $10 \%$. The typical after-tax rate of return for most third-party developers is closer to $15 \%$, but there appears to be a suite of renewable energy developers willing to accept a lower return. Both costs and prices were assumed to escalate with an inflation rate of $1.9 \%$. It should be noted that third-party investors would probably need to negotiate backup power options with both the installation and El Paso Electric to assure that WSMR doesn't face substantial emergency power costs for any unplanned outages. 


\section{Energy Conservation Investment Projects}

The assumptions for ECIP are driven by the Federal Energy Management Program. Table A-2 lays out the discount rates underlying the model as of April 2007. The real and nominal rates for DOE/FEMP imply a 1.9\% inflation rate. New rates were obtained from Marlin Addison (2007).

Table A-2: Discount Rate Assumptions in the ECIP model

\begin{tabular}{|r|c|c|c|c|c|c||}
\hline Discount Rate & DOE FEMP & OMB 3-year & OMB 5-year & OMB 7-year & OMB 10-year & OMB 30-year \\
\hline real & $3.0 \%$ & $2.5 \%$ & $2.6 \%$ & $2.7 \%$ & $2.8 \%$ & $3.0 \%$ \\
\hline nominal & $5.0 \%$ & $4.4 \%$ & $4.5 \%$ & $4.7 \%$ & $4.8 \%$ & $5.0 \%$ \\
\hline
\end{tabular}

\section{FATE2-P Model Description}

The FATE2-P (Financial Analysis Tool for Electric Energy Projects) financial analysis model was used to evaluate the feasibility of renewable energy projects at WSMR. The spreadsheet model was developed by Princeton Economic Research, Inc. and the National Renewable Energy Laboratory for the U.S. Department of Energy. FATE2-P can be used to develop pro forma financial statements for a utility using a revenue requirements approach or an independent power producer using the discounted rate of return approach. Both approaches are diagrammed in Figure A-1. Other models produce very similar results given the same inputs. The revenue requirements approach follows a cost-based utility revenue requirements analysis, and the independent power producer approach uses a market-based discounted cash flow return. The FATE2-P model has been updated by PNNL to include the MILCON Energy Conservation Investment Program Module in addition to the rate of return methodology. The model has been used to model improved technology designs, resource variability, and favorable tax treatment on renewable energy products. The advantage this model over other models is that it is already suited for handling all of the renewable energy technologies in this study through one model, thus providing results on a comparable basis across all technologies. 

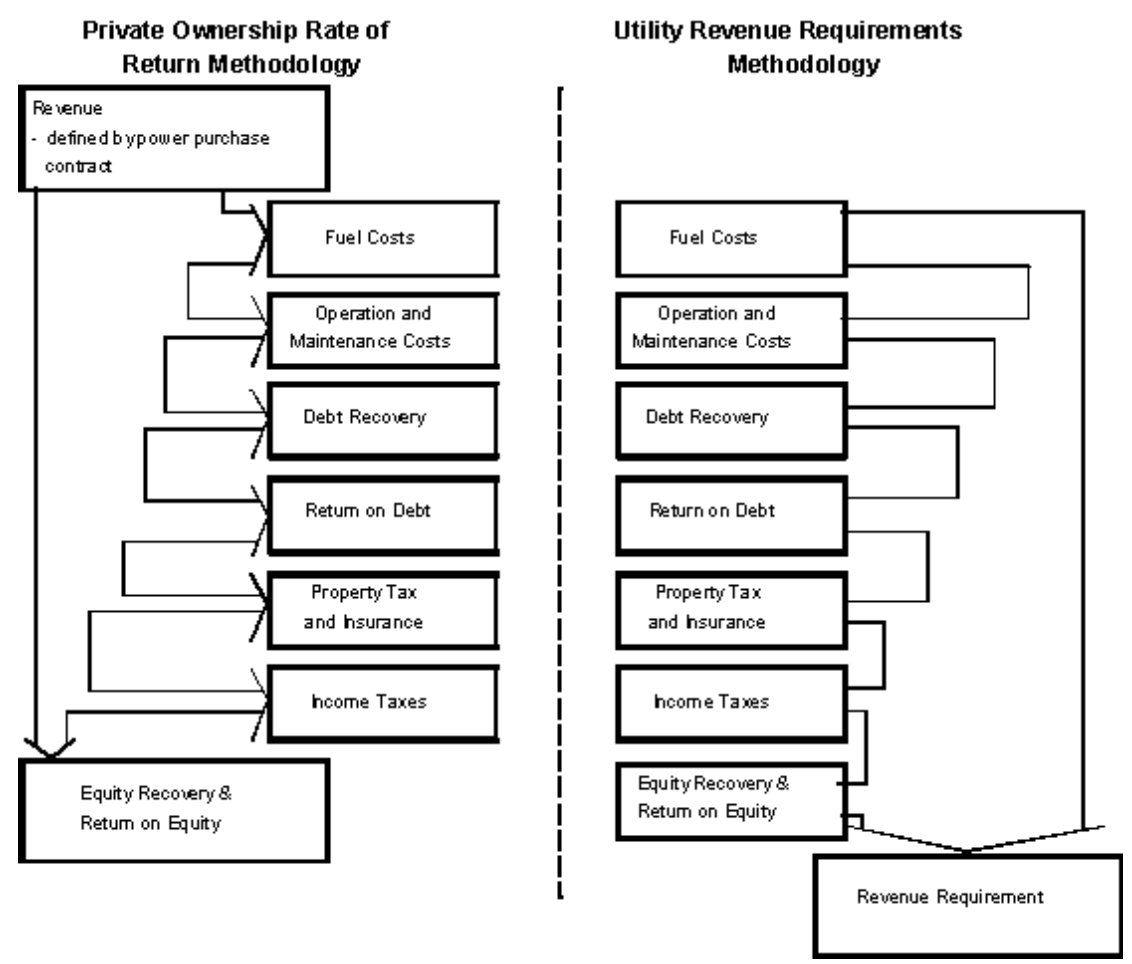

Figure A-1: FATE2-P Methodology

\section{Private Ownership Rate of Return Methodology}

The private ownership rate of return module (independent power producer) develops an annual aftertax cash flow based on the revenues defined in the power purchase contract and costs associated with constructing and operating the generation facility. The goal of this approach is to capture the relevant investment costs after-tax and compare them with the net cash flow from the investment after-tax over time. The model contains sections to capture the relevant costs of construction including the debt and equity capital accumulation to purchase the investment and the associated payback of debt and equity capital. In addition, the model has sections associated with revenue generation, cash flow, an income statement and associated statements to calculate tax liabilities to capture after-tax cash flow. The financing section includes several pertinent sections including sources and uses, construction and debt accumulation, reserve funds requirements, debt schedule, amortization of debt fees, and debt service coverage ratios.

$\checkmark$ The sources and uses of funds section shows the allocation of construction funds between components and sources of those funds. Uses of funds include construction cost, AFUDC (allowances for funds used during construction), underwriters' fees for both debt and equity.

$\checkmark$ The construction and debt accumulation statement is capable of handling a 6-year construction period starting at any date. Any construction draw schedule can be used for 1 to 6 years. An equal percentage draw schedule for each year of any given construction length is the default.

$\checkmark$ The model contains major maintenance and debt-service reserve funds. Both types of accounts generate interest income that becomes a part of the income statement through a drawn-off interest calculation. The model doesn’t currently calculate a working capital 
reserve account. Such an account would add interest costs to the cost statement in addition to the interest costs on the capital investment.

$\checkmark$ The debt schedule allows three types of financing: level payment, bullet, and customized. Level payment is pretty customary for projects that have adequate cash flow to satisfy debt coverage payments and are of short duration. Customized is required when certain years fall below the minimums set by the investment banking industry.

$\checkmark$ Cash flow statements can be constructed for up to 30 years of revenue generation plus the 6year construction time frame.

$\checkmark$ The revenue module contains a variable capacity factor that must be filled in by the analyst to capture depletion of the geothermal fields, the capacity of wind or of the other renewables' capacities. This section also allows for secondary energy by-product credits (such as for steam if it has value), and up to six different types of subsidy payments if available. The model also accepts after-tax production credits, if available and includes any interest on reserves.

$\checkmark$ Cash expenses statements include standard operations and maintenance costs (both fixed and variable), general and administrative (G\&A), insurance, and land fees. There is major maintenance expense along with a reserve fund dedicated to covering the major maintenance expense when it occurs. Up to two different fuel costs can be entered. There is also an entry for royalty fees associated with geothermal.

$\checkmark$ The earnings statement in this model calculates earnings and taxes based on a tax table. Operating income is generated by subtracting cash and operating expenses from revenue, as described in the section above. Taxable income is determined by subtracting cash and noncash expenses such as interest, depreciation, amortization of fees, IDC (interest during construction) and depletion allowances. Taxes paid and tax credits received are netted and after-tax book income is calculated. The net taxes paid become a part of the cash flow.

$\checkmark$ The model includes straight-line and MACRS (modified accelerated cost recovery system) depreciation approaches, with mid-quarter convention deprecation tables. Straight-line allows for the calculation of book basis value of assets and liabilities while MACRS allows for the taxable basis of the investment.

$\checkmark$ The model amortizes debt related fees over 15 years and equity organizational fees over 5 years. Equity tax advice is expensed in the first year, and equity broker fees are excluded.

$\checkmark$ The model calculates depletion allowances on geothermal projects. The model also depletes certain AFUDC when appropriate.

$\checkmark$ Income tax and other tax statements are prepared for federal and state taxes paid as well as tax credits earned. Tax calculations include excise taxes, federal, state and local taxes. Depreciation calculations used to capture after-tax cash flow can use either straight-line or MACRS. There is also section to incorporate local property taxes and special tax assessments. 
$\checkmark$ Assumptions: The assumptions section is fairly extensive and covers construction costs, debt acquisition, equity acquisition, capacity factors, fixed and variable operations and maintenance (O\&M) inputs, financial factors such as interest rates, general and administrative expenses, real escalation in O\&M charges, unfired fuel assumptions, byproduct credits, asset life, inflation rates, tax rates, property tax rates, insurance, Investment tax credits, AFUDC, local gross receipts tax, and special property tax assessments.

$\checkmark$ Total plant cost (overnight) is divided into: sales tax; rotor, gearbox, generator; tower and civil work; controls, transformer, interconnect; design/engineering; permitting/ environmental, construction labor and supervision; contingency; home office overhead; real escalation in construction cost; miscellaneous depreciable cost (last year of construction); sales tax on miscellaneous depreciable cost; land cost; and startup cost.

\section{ECIP Module}

The FATE2-P model includes a life cycle cost module based on the Buildings Life Cycle Cost (BLCC) model (produced by the National Institute of Science \& Technology) and a MILCON Energy Conservation Investment Program (ECIP) module, which in turn fills out Form 1391. The ECIP module currently reflects 2007 forecast discount and inflation rates. The ECIP module provides first year savings, simple payback, total discounted operational savings, savings-toinvestment ratio (SIR), and adjusted internal rate of return.

\section{The Federal Energy Decision System (FEDS) Model}

FEDS is a building energy modeling software developed by Pacific Northwest National Laboratory to support the economic analysis of efficiency technologies at large, multi-building sites. Building characteristics are entered into the model using as much detail as possible, and the model uses the given information to make inferences for the remaining characteristics. Multiple sets of building data can be entered into the same model, so that an entire site can be represented at once. The optimization cycle uses data about the location of the site and the energy prices entered into the model to determine cost-effective retrofits for each set of building data, and to calculate costs and savings. The suggested retrofits can range from lighting to building envelope to HVAC, covering all aspects of a building's energy use and considering interactive effects. In addition, the model can be adjusted to consider just one type of retrofit. In this renewable analysis conducted at WSMR, ground source heat pumps were the only technology analyzed. 


\section{Business Case Analysis References}

Addison, M.S. and Associates, Tempe, AZ. 2007. "User-Friendly Building Life-Cycle Cost Analysis.” marlin.addison@doe2.com; provided June 2007.

CTR-Dona Anna, 2007, “Certificate of Tax Rates: Dona Ana County, Tax Year 2007.”

CTR-Otero, 2007, “Certificate of Tax Rates: Otero County, Tax Year 2007.”

DSIRE. 2007a. Federal Incentive for Renewables and Efficiency: Business Energy Tax Credit. http://www.dsireusa.org/library/includes/incentive2.cfm?Incentive_Code

=US02F\&State=federal\&currentpageid=1\&ee=1\&re=1. Date visited 8/29/2007.

DSIRE 2007b. "New Mexico Incentives for Renewable Energy."

http://www.dsireusa.org/library/includes/map2.cfm?CurrentPageID=1\&State=NM\&RE=1\&EE=1. Date visited 6/13/2008

H.R.6111. December 2006. “Tax Relief and Health Care Act of 2006” (Enrolled as Agreed to or Passed by Both House and Senate). Section 207

(JCT) Joint Committee on Taxation. October 4, 2007. “Description of the Chairman's Modification to the Provisions of the "Heartland, Habitat, Harvest and Horticulture Act of 2007" (JCX-96-07),

Rushing, Amy S., Barbara C. Lippiatt. May 2007. “Energy Price Indices and Discount Factors for Life-Cycle Cost Analysis - April 2007: Annual Supplement to NIST Handbook 135 and NISTIR 853273-22 (Rev. 5/07)”. NBS Special Publication 709

United States Code Service. 26 USC § 48. Title 26. Internal Revenue Code. Subtitle A. Income Taxes. Chapter 1. Normal Taxes and Surtaxes. Subchapter A. Determination of Tax Liability. Part IV. Credits Against Tax. SubPart E. Rules for Computing Investment Credit

U.S. Department of Treasury. "2007 Instructions for Form 4562: Depreciation and Amortization (Including Information on Listed Property.” Internal Revenue Service.

United States Code Service. 26 USC $\S 168$ (2006). Title 26. Internal Revenue Code. Subtitle A. Income Taxes. Chapter 1. Normal Taxes and Surtaxes. Subchapter B. Computation of Taxable Income. Part VI. Itemized Deductions for Individuals and Corporations

United States Code Service. 16 USC § 796 (2006). Title 16. Conservation. Chapter 12-Federal Regulation and Development of Power. Subchapter 1. Regulation of the Development of Water Power and Resources. Definitions. 


\section{APPENDIX B}

\section{Analysis of Biomass and Waste-to-Energy Opportunities}


Renewable Energy Opportunities at White Sands

Missile Range, New Mexico

Pacific Northwest National Laboratory, Sept 2008 


\section{Appendix B: Analysis of Biomass and Waste-to-Energy Opportunities}

\section{Biomass and Waste-to-Energy Technology}

The term "biomass" refers to renewable fuels used for power production that include methane from landfills and wastewater treatment plants, agricultural waste, forest and wood processing waste, animal waste, industrial waste, dedicated biomass crops, and landfill gas. Waste-to-energy (WTE) is similar, but includes municipal solid waste (MSW) and construction and demolition (C\&D) waste as fuel sources. The Energy Policy Act of 1992 (EPAct) and some states and federal agencies (including DOE) differentiate these feedstocks into those that qualify as renewable sources for compliance purposes, and those that do not. While biomass and WTE projects may be very different as to their sources, fuel collection modes, and fuel cost profiles, in the end, energy production often relies on similar technologies.

The primary technologies for producing electricity rely upon steam turbines, gas turbines, or combined cycle turbine generators. Generators are energized by steam produced from direct combustion of raw material, or a synthetic gas (syngas) produced through anaerobic digestion or gasification. Direct combustion and anaerobic digestion technologies are mature and have been proven commercially. Gasification technologies are newer in the market, but are promising based on a number of successful installations. Anaerobic digestion is widely used but primarily for smaller applications in rural and municipal projects rather than large commercial installations.

The capital cost of biomass plants ranges from about $\$ 1500$ to $\$ 5000 / \mathrm{kW}$, depending upon scale and specific technologies used. Direct combustion technologies tend to be both larger and less capital intensive than those based on syngas. Digesters tend to be higher cost, primarily because of their smaller size. Operation and maintenance (O\&M) for digesters is also more, costing about $2.0 \$ / \mathrm{kWh}$, compared to about $1.0 \mathrm{\$} / \mathrm{kWh}$ for combustion plants. The advantage for digesters is the low cost of fuel, which is typically free, local waste (i.e., sewage sludge, manure). Even a "free" feedstock, such as crop wastes, does not guarantee a successful project, as collection, transportation, and storage costs can be, and often are, economically prohibitive. The economics of municipal solid waste (MSW) projects are typically more attractive than other biomass projects because fuel is often delivered free or even accompanied by payment in the form of a tipping fee. Most landfills are operated or franchised by a local government. Many of these derive operating revenues from fees that are added to the actual operating costs of the landfill. As a result, the tipping fee may be inflated over actual costs and therefore not an accurate representation of costs that can be avoided.

Combustion (direct-fired) systems burn biomass to produce steam in a boiler, turning a turbine connected to a generator. This method of producing electricity is quite inefficient, at about $20-30 \%$. In direct-fired systems, combustion products tend to form deposits on the heat transfer surfaces, increasing maintenance requirements and decreasing the lifetime of these surfaces because of corrosion and erosion. Ash has to be collected and removed from the system. The variability of incoming feedstock in terms of its composition and moisture content can present problems in combustion systems, most notably with MSW and mixed feeds. Systems that use a more homogeneous feedstock benefit from more complete combustion, which increases efficiency and reduces combustion waste products and emissions. Various boiler designs try to address these issues.

Gasification is more efficient than combustion, but the technologies employed are not as mature or common in commercial operation. Gasification uses oxygen, steam, heat, and pressure to break 
down organic materials to produce syngas, which is primarily hydrogen and carbon monoxide. Syngas is cleaned to remove impurities, then used to generate electricity in a gas turbine or fuel cell, or used to produce transportation fuels or commercially valuable chemicals. The inorganic materials are discharged as inert solids that can often be used for another purpose. There are many types of gasification designs that use different amounts of oxygen and steam at different stages and temperatures, producing different amounts of waste heat, syngas, and solids.

One gasification process is just entering the commercial market now for use with MSW, but is worth noting because of its high potential and interest for use on military sites. The plasma melter uses plasma to heat the material being gasified, resulting in a much higher temperature and more complete reaction. This new technology produces only syngas from the organics, molten metal from any metals, and a hard glass-like substance from the inorganics. No emissions are created during this process, and the solid waste can be sold and used for other purposes. Ash collected from syngas cleaning can be fed back into the plasma melter. Hazardous materials can also be gasified in this process, sealing the toxic substances into the solid waste with no potential for leaching.

Digesters tend to be smaller systems and are typically used just for biomass. They are usually located at the biomass source, such as farms with significant amounts of animal manure and wastewater treatment facilities. Digesters break down biomass in warm, wet environments to produce methane, which can be captured as fuel for generating electricity. Aerobic digesters are common in poor countries for production of heating and cooking fuel in rural areas. Anaerobic digesters limit the amount of oxygen in the gasification process and therefore produce gas with a higher concentration of methane, which is better for power production. Because of the smaller size of digester systems, electricity is typically generated using fuel cells, microturbines, or reciprocating engines.

Methane is also produced through anaerobic digestion in landfills as the garbage underground breaks down. It is sometimes left in the ground, but the risk of fire has led most landfills to remove the methane and flare it in a controlled manner. The flare could be replaced with an electricity generation system if the economics are positive. The most economic opportunities for landfill methane capture and use are in cases where the landfill already has a collection system in place, is active or recently closed (methane production tapers off as landfills age), and has sufficient waste (typically at least 1 million tons) to generate a significant amount of methane. The landfill must be lined as well, to prevent water intrusion into the landfill that stifles digestion of the waste and methane production and to prevent the methane from migrating into the surrounding soil. New landfills are typically lined by law, although many older ones are not. Methane production even from large landfills is relatively low; as a result, power facilities that use it are typically small systems located on site using fuel cells, microturbines, or reciprocating engines.

For all of these technologies, except landfill gas, a power plant will require feedstock storage space, feedstock preparation equipment, feed equipment, processing equipment, product cleaning and collection equipment, electricity generation equipment, ash and waste storage space, water for steam and cooling, and emissions control equipment. The specific infrastructure and space required for each of these depends on the type of feedstock and process used and on existing site conditions. Some feedstocks require year-round storage, as they are only available seasonally (e.g., agricultural residue); some feedstocks are available almost continuously and require less storage space (e.g., municipal solid waste). The size of the system will depend on the amount of feedstock available. As an example of space needed, one plasma gasification project we evaluated could process 250 tons of 
MSW in an 80-ft by $175-\mathrm{ft}$ area, not including storage space. Any existing electrical generation equipment may be able to be used with a new gasification system, reducing site requirements, only needing sufficient space next to the existing system for the new equipment and connection lines.

Emissions control requirements depend upon the process used and on regulations affecting the site. Some gasification processes produce no criteria pollutants, such as $\mathrm{SO}_{\mathrm{x}}$ and $\mathrm{NO}_{\mathrm{x}}$. However, air emissions are inevitable if the resulting syngas is burned in a conventional power generator. Air emissions are not expected to pose a problem at WSMR.

\section{Biomass and Waste-to-Energy Analysis Approach}

The critical factor in determining feasibility for biomass energy generation is feedstock availability. As listed above, there are a number of potential feedstocks, and each one was evaluated for use at WSMR. The following questions were asked about each feedstock:

$\checkmark$ Does this material exist in the surrounding region within 60 miles? (30 to 60 miles is assumed to be the maximum economic transport distance.)

$\checkmark$ How much is available within this area, on average? Is availability constant or variable, depending on crop rotation cycles and/or market conditions?

$\checkmark$ How much is available for use as a feedstock? Availability is based on the feedstock being able to be collected and the lack of competing uses or markets. For example, wheat straw it typically left in the field to protect and rebuild the soil. If it is collected, the resulting bales may have higher value as animal bedding than as fuel, creating a competing market for what was otherwise a waste material on the ground.

$\checkmark$ How much electricity can be produced from the available biomass? This is a function of the quantity of material available, moisture content, and its relative heat value.

In this analysis, if the electricity available from a feedstock were less than $1 \mathrm{MW}$, it was not considered a feasible resource. The narrowed list of possible feedstocks was then evaluated on a simple economic basis. Feedstock costs were estimated based on tipping fees, collection costs, transportation costs, current market rates, and other relevant information. Other operational costs and construction costs were estimated by scaling existing plant data for the three primary technology types. Based on the amount of feedstock available and the size of plant required, a levelized cost of electricity was estimated for each.

For any options that are reasonably close to being cost effective, further economic analysis was completed, including evaluating tax credits and other incentives, different financing options, ranges of potential construction and operation costs, and ranges of feedstock costs and amounts. WSMR's average electricity cost of $7.41 \mathrm{c} / \mathrm{kWh}$ was used for this economic analysis.

Any associated risks or potential issues with these remaining options were noted to present all considerations surrounding an implementation decision. When possible, these were quantified.

PNNL staff created a new tool that supports analyses of various plant sizes, costs, and fuel sources in a generic manner. This facilitates "what if" analyses where critical information about fuel source and cost is unavailable. The result is an estimate of what power from a project would cost using available data and staff assessments for missing data. It also allows staff to reverse engineer an answer using 
WSMR's power cost as a given. Specifically, the tool can be set up to provide an estimate of what size plant and fuel cost is needed to produce power for less than the current and projected future power rate. Data from a 2003 NREL study of biomass fuels was used to initiate the analytic tool. The 2003 study costs were converted into 2007 dollars and scaled according to varying plant sizes following the methodology used in the study. Any size plant can be evaluated and any value can be varied to test for financial feasibility. The tool was only used for preliminary screening because it does not adequately address taxes, incentives, or other factors. These economic factors have a significant impact on project feasibility, especially if it is assumed the power project will not be owned and operated by the government.

This analytic approach was used to evaluate all biomass options, without making preliminary assumptions about any feedstocks or technologies. In other words, it was used to develop preliminary estimates of electric generation costs using a "What if feedstock X were available?" The results of this preliminary analysis are useful for framing a biomass or waste energy strategy. If the analysis resulted in estimated costs that are unrealistically high, the option was rejected.

\section{Biomass and Waste Resource Characterization}

The following biomass and waste types were assessed for potential as feedstocks.

$\checkmark$ Agricultural (crop residues, animal waste, dedicated biomass crops)

$\checkmark$ Forest (thinnings, logging slash)

$\checkmark$ Industrial (mill residue, other industry waste)

$\checkmark$ Waste (MSW, urban wood waste, landfill gas, biogas or biosolids from wastewater treatment plants).

\section{Agricultural Biomass}

The USDA has a database of agricultural production information by county and state. Information was gathered here about corn, wheat, other crops/orchards/vineyards, and poultry, pig, and cow production.

\section{Crop Residue}

Crop residues are the plant remains in the field after harvest. Some crops have more residues than others; some, like hay, have no residues at all because the entire plant is harvested. A certain amount of residue left on the soil minimizes erosion and maintains nutrients in the soil. However, too much residue can inhibit growth of a new crop. Depending on tilling practices, climate, crop type, soil type, and slope of the land, residue may or may not be available for removal. In general, conventional till practices need more residue than no-till practices; warm wet climates need more residue than cold dry climates; corn fields need more residue than wheat fields; coarse, well-drained soils need more residue than poorly-drained, heavy clay soils; and steeper slopes need more residue than flat land. In addition, crop residue availability is dependent on competing uses, like cattle feed, and seasonal yields, which can change dramatically from year to year.

In 2006 and 2007 in counties within 60 miles of WSMR, an average of 4.5 million bushels of corn, 195,000 bushels of sorghum, and 44,000 bales of cotton were produced. These harvests left about 124,000 tons of corn stover, 5,000 tons of sorghum residue, and 4,000 tons of cotton residue on the fields. Available residue for biomass will be somewhere between these values and zero. It can be 
assumed for now that about $30 \%$ of the corn and sorghum residues and $90 \%$ of the cotton residues can be collected, resulting in about 37,000 tons of corn stover, 1,500 tons of sorghum residue, and 4,000 tons of cotton residue available for use. These numbers will have to be verified on a farm-byfarm basis for a more accurate analysis. No crops are farmed on WSMR land.

This amount of corn stover could be used to generate 3 to $4 \mathrm{MW}$ of electricity. The sorghum could generate 0.1 to $0.2 \mathrm{MW}$, and the cotton residue could generate 0.3 to $0.4 \mathrm{MW}$. In total, crop residues could generate 3.7 to $4.8 \mathrm{MW}$ of electricity.

It would cost about $\$ 10 /$ ton to transport the residues to the plant, and about $\$ 10 /$ ton for the farmer's collection effort. Therefore crop residue feedstock cost is about \$20/ton. Using all crops together to gain the most benefit from economy of scale, the most cost-effective biomass option would be combustion, producing electricity at $14 / \mathrm{kWh}$. This is more expensive than WSMR's commercial rate, and is not an economic option at this time.

In addition, residue availability is dependent on competing uses, including cattle feed, which can pay almost \$42/ton for corn stover. Availability is also dependent on seasonal yields, which can change dramatically. Sufficient on-site storage of the residue is important to avoid incurring further costs for storage elsewhere. A significant amount of space is required to store crop residue because it is only available twice a year, after harvest.

As a result of electricity generation cost, the variability in fuel supply, and competition with alternative markets, it is not recommended to pursue crop residue as a biomass resource.

\section{Animal Waste}

Manure from cattle, swine, and poultry farms is generally cleaned out of housing and feeding areas and used as fertilizer for crops. This has become a problem because of over-application. Bad odors and groundwater contamination are forcing farmers to find other ways to dispose of manure. Anaerobic digestion technologies can turn wet manure into energy, and often can be used with existing collection and treatment systems. Poultry waste has much lower moisture content than cow or swine manure, and can be used in combustion or gasification systems.

In 2007-8, there were no cattle feed lots within 60 miles of WSMR. All 400,000 cattle, many of which are beef cattle, were kept in pastures. Manure in pastures is not good feedstock material because it is not typically collected (increasing the costs and decreasing the heating value as it dries in the field). Only the manure from cattle on a feedlot can be assumed to be available for electricity generation, and there are none within economic range of the site.

If all non-beef cattle and calves in the area were considered, assuming that they may also spend some time in a feedlot, the manure could generate about $33 \mathrm{MW}$ of electricity. However, using manure to generate energy at any distance from the source will not be cost effective. Cow manure is only $12 \%$ solids as excreted, and then is typically collected with a flush system, watering it down even further. On a dry basis, manure has an energy content of about $17 \mathrm{MMBtu} / \mathrm{ton}$, and is transportable; but wet manure has an energy content of about $2 \mathrm{MMBtu} /$ ton or less. Drying the manure on site would incur costs to the farm, and then the manure would have to be sold at a profit for the farmer. These costs would be in addition to transportation costs, which would typically be about \$10/ton. Transporting wet manure would increase costs (as a result of increased volume and hence increased number of 
trucks) beyond what is economically feasible. Because of the expenses of liquid removal, transportation, and anaerobic digestion equipment, using manure for energy generation at WSMR is not feasible.

Consideration is currently being given to using 12,000 acres of WSMR land for cattle grazing. Manure deposited on this land would not require extensive transport to be used in an anaerobic digester, but it would not be easily or inexpensively collected from the open field. Therefore, even this local source of animal waste does not present a feasible biomass opportunity.

\section{Dedicated Crops}

Dedicated energy crops include switchgrass, hybrid poplar, willow coppice, and other SRWC (short rotation woody crops). These are fast-growing plants that can be harvested for use as energy in various forms. Switchgrass is a native prairie grass that grows best in warm dry climates like the Midwest. SRWC need lots of water and do well in colder climates like the Northeast. They need at least 16 inches of rainfall per year, or need to be located on a body of water. Dedicated crops are not a readily available resource. Rather, agricultural land where the crops can be grown is the resource to be evaluated, and the feedstock cost would be based on the cost to farm that land, harvest the resource, and deliver it to the generation plant on Post.

None of these crops are suited to the region near WSMR. The soil and climate do not naturally favor crop growth, and irrigation or other extensive agricultural practices are cost-prohibitive. Therefore, dedicated energy crops are not a feasible biomass option.

\section{Forest Biomass}

\section{Forest Thinnings and Logging Slash}

Logging slash includes branches, stumps, and other material that is generated during logging practices but left behind because it is not useful to the loggers looking for large tree trunks. Once this slash is cut and left on the forest floor, it dries out, becoming good fuel for fires. It also can get in the way of machinery during replanting efforts. Sometimes it is gathered into small piles and burned in a controlled manner to reduce the risk of widespread forest fire, but this practice pollutes the air and may be restricted by air quality regulations. Instead, it can be collected and transported to a biomass facility where the emissions can be controlled and the wood waste can be put to good use.

Forested areas near WSMR are primarily in or near the Lincoln National Forest in Otero and Lincoln Counties. There were about 17,700 tons of slash left in the forests within 60 miles of WSMR in 2007. Assuming a recoverability factor of $50 \%$ as a result of site accessibility, steepness of slopes, and retrieval efficiency, about 8,800 tons are available. This amount could power a plant of about 1.2 MW.

On WSMR, about 8\% of the installation is covered in pinyon pines, which can grow to be very thick in areas. Occasionally prescribed burns are used for habitat management, but more need to be done. In addition, plans are being made to begin thinning the pines in patches at a rate of 4,000 to 5,000 pounds per acre. The rest of the installation is covered in grasslands and shrublands. These areas are also occasionally burned for rejuvenation, and herbicide use is planned for better control. Assuming a recoverability factor of $50 \%$ for the planned pine thinning, about 18,400 tons of woody waste will be available. This could generate about $2.5 \mathrm{MW}$ of electricity; therefore, all slash would generate about 3.7 MW. 
It would cost about $\$ 10 /$ ton to transport the off-site wood waste to the plant, about $\$ 8 /$ ton to transport the on-site waste, and about $\$ 2 /$ ton for the collection effort. Therefore, the average feedstock cost is about $\$ 10.65 /$ ton. The most cost-effective biomass option would be combustion, producing electricity at about $12 \mathrm{c} / \mathrm{kWh}$. This is more expensive than WSMR's commercial rate, and is not an economic option at this time.

\section{Industrial Biomass}

Industrial biomass includes mill residue, food processing waste, textile waste, or waste from other specialized operations.

\section{Mill Residue}

There are many types of mills that use wood to produce various products, including lumber, shake and shingle, pulp, veneer and plywood, log chips, and posts, poles, and pilings. These processes generate waste in the form of sawdust and wood pieces, which are useful materials. In fact, most mill residue is currently used for fiber, fuel, or other uses.

Mills near WSMR used all but 7\% of mill residue for these other products. There are only about 4,000 tons of unused mill residues available for use as biomass. This amount could only produce about 0.6 MW of electricity. While not a sufficient amount of feedstock on its own, mill residue may be able to be combined with other woody feedstocks.

\section{Other Residue}

Typically industrial processing generates waste that can be costly to get rid of or could be useful material for another industry. Many industries try to sell their scrap material instead of paying to landfill it, which means it is unavailable or costly for use as biomass feedstock. Other industries would be glad to see their waste put to some use, and would give it away for free or pay a small amount to have it hauled away.

To meet WSMR's electricity price, a 60-MW plant would have to be built using industrial waste. The net cost of the waste would have to be $\$ 8$, which means industries would need to give their waste away for free or pay a small amount that would balance the cost of transport to the site, which is about $\$ 10 /$ ton, depending on the distance traveled. At least 540,000 tons of waste would be needed per year.

Because the area landfills don't even collect that much waste, it can be assumed that that amount of industrial waste will not be available. Therefore, this is not an option for WSMR.

\section{Waste Biomass}

\section{Municipal Solid and Urban Wood Waste}

Municipal solid waste (MSW) and construction and demolition (C\&D) waste are being generated at greater rates each year while landfills are filling up, resulting in greater hauling distances and increasing prices for waste disposal. Recycling is one way to reduce the strain on landfills; using the waste to generate energy is another. Some recyclables, like metals, must be separated out before waste is used for energy generation. All carbon-based materials, however, can be used to generate energy.

WSMR produces approximately 1,200 tons of MSW per year that goes to the Otero-Lincoln County Regional Landfill, which is located 24 miles south of Alamogordo, between WSMR and Fort Bliss. 
The landfill is relatively new and has plenty of space for future waste, so other waste going there will not be available. Las Cruces is the closest city to WSMR, and owns the Amador Transfer Station located in town, as well as the Corralitos Landfill 15 miles west of Las Cruces. The transfer station processes about 240,000 tons of waste per year, and the landfill collects about 300,000 tons per year, mostly from the Amador Transfer Station. These are summarized, with their respective tipping fees, in Table B-1.

WSMR pays the Landfill \$22/ton to deliver waste there. The Amador Transfer Station charges $\$ 30.70 /$ ton for waste deposited there. The Corralitos Landfill charges \$24.80/ton.

Table B-1: Municipal Solid Waste Near WSMR

\begin{tabular}{||l|l|c|r|r||}
\hline \multicolumn{1}{|c|}{ Site } & \multicolumn{1}{|c|}{ Collection Location } & $\begin{array}{c}\text { Miles } \\
\text { from } \\
\text { WSMR }\end{array}$ & $\begin{array}{c}\text { Tipping } \\
\text { Fee (\$) }\end{array}$ & $\begin{array}{c}\text { Available } \\
\text { MSW } \\
\text { (tons/year) }\end{array}$ \\
\hline \hline White Sands Missile Range & White Sands Missile Range & 0 & $\$ 22$ & 1,247 \\
\hline Amador Transfer Station & Las Cruces, NM & 20 & $\$ 30.70$ & 240,240 \\
\hline Corralitos Landfill & Las Cruces, NM & 35 & $\$ 24.80$ & 300,000 \\
\hline & \multicolumn{3}{|c|}{ TOTAL AVAILABLE } & $\mathbf{3 0 1 , 2 4 7}$ \\
\hline
\end{tabular}

WSMR does not generate sufficient waste to run a WTE plant on its own; waste would have to be imported. Using the Amador waste, WSMR could generate up to $33 \mathrm{MW}$ of electricity. With Corralitos waste, WSMR could generate up to $41 \mathrm{MW}$. Because the tipping fee is higher at the transfer station and because it is closer to WSMR, thus reducing transport costs, waste from there should be considered as a separate option. C\&D waste is included with MSW in this region.

\section{Landfill Gas}

Methane generated from decomposing waste is a combustible pollutant that must be controlled. It is typically vented or collected and flared to avoid buildup and hence danger of explosion. Collected methane can also be used as a fuel to generate heat or electricity.

WSMR does not have a landfill on site, and there are no other nearby landfills that could be used for gas collection. Therefore, landfill gas is not a viable option for WSMR.

\section{Wastewater Treatment Plant (WWTP) Sludge}

WWTP sludge is the remains after wastewater is treated and the clean water is returned to the ground or other body of water. It has a high-energy content when dried, but the drying process is energyintensive and necessary for any transportation. Sludge is similar in substance to manure; it is a very watered-down substance that is best processed on site, where energy is generated with anaerobic digestion. Therefore, only on-site sources of sludge are reasonable to use for energy generation.

WSMR has a WWTP on site that processes about 350,000 gallons per day, producing about 164,000 tons of wet sludge and about 10,220 dry tons of biosolids per year. A 1-MW plant needs at least 13,000 tons of sludge per year. Therefore, the WSMR WWTP does not process enough wastewater 
to be considered for electricity generation. However, the plant capacity is 1 million gallons per day, which would more than double the amount of biosolids produced. If water consumption and discharge greatly increase in the future, this option could be reconsidered. However, for now it is not a feasible option.

\section{Biomass and Waste-to-Energy: Economic and Other Analysis Parameters}

Data used in this analysis were obtained from local sources when possible, and the economic assumptions were generally conservative. The economic performance of MSW plants determined through a more detailed, design-level analysis should lie in the same ballpark as results presented here. Our assumptions are presented in the report. However, any significant changes to important assumptions may change outcomes-opportunities that are barely economic in this report may no longer be economic if the values are changed significantly.

\section{Findings: Biomass and Waste-to-Energy Opportunities}

The following biomass fuels are not worth pursuing, because of a lack of resource availability:

$\checkmark$ Dedicated biomass crops

$\checkmark$ Mill residue

$\checkmark$ WWTP sludge

$\checkmark$ Landfill gas

$\checkmark$ Other industrial waste

The following biomass fuels are not worth pursuing because of unfavorable economics:

$\checkmark$ Crop residue $(14 \$ / \mathrm{kWh})$

$\checkmark$ Animal waste $(20+\$ / k W h)$

$\checkmark$ Forest thinnings \& logging slash $(12 \mathrm{c} / \mathrm{kWh})$.

MSW, including urban waste wood, is the best option for generating electricity at WSMR. Project economics will depend on the availability and price of waste, and actual plant size, capital costs, and operating costs. The economic assumptions used to analyze each scenario are listed in Table B-2. The assumptions that vary per scenario are listed below with the results. The average cost of electricity that WSMR would pay for the renewable energy was assumed to be $7.41 \mathrm{~d} / \mathrm{kWh}$. 
Table B-2: Economic Assumptions, constant $\$ 2007$

\begin{tabular}{|c|c|}
\hline \multicolumn{2}{|l|}{ Economic Factors } \\
\hline Inflation & $1.9 \%$ \\
\hline Interest Rate & $10.0 \%$ \\
\hline Debt/Equity Ratio & N/A \\
\hline Real Discount Rate & $3.0 \%$ \\
\hline \multicolumn{2}{|l|}{ Tax Considerations } \\
\hline Federal Depreciation & MACRS \\
\hline Federal Tax Rate & $35 \%$ \\
\hline State Income Tax Rate & $7.6 \%$ \\
\hline State Sales Tax & $0.0 \%$ \\
\hline Property Tax Rate & $1.0 \%$ \\
\hline \multicolumn{2}{|l|}{ Incentives } \\
\hline Federal Production Tax Credit & $\$ 0.01 / \mathrm{kWh}$ \\
\hline State Production Tax Credit & $\$ 0.01 / \mathrm{kWh}$ \\
\hline Federal Energy Tax Credit & $0 \%$ \\
\hline State Energy Tax Credit & $0 \%$ \\
\hline Utility Rebate & $\$ 0 / \mathrm{kW}$ \\
\hline \multicolumn{2}{|l|}{ Technology } \\
\hline Plant Life & 30 years \\
\hline $\begin{array}{l}\text { Capacity Factor (basis net kW } \\
\text { output): Total System }\end{array}$ & $85 \%$ \\
\hline $\begin{array}{l}\text { Real Escalation in Construction } \\
\text { Cost }\end{array}$ & $0 \%$ \\
\hline $\begin{array}{l}\text { Misc. Depreciable Cost (last } \\
\text { year of construction) }\end{array}$ & $\$ 0$ \\
\hline $\begin{array}{l}\text { Sales Tax on Misc. Depreciation } \\
\text { Cost }\end{array}$ & $\$ 0$ \\
\hline Land Cost & $\$ 0 / \mathrm{kW}$ \\
\hline Startup Cost & $\$ 0 / \mathrm{kW}$ \\
\hline
\end{tabular}

As previously mentioned, there are a couple options to consider when using MSW for energy production: site waste with Amador Transfer Station waste and site waste with the landfill waste. In addition, each of these options can use combustion, gasification, or plasma melting. The combinations that are cost effective or close to cost effective are presented in Tables B-3 and B-4.

The feedstock costs used are based on a weighted average of the avoided costs of the waste used in each scenario. WSMR avoided cost is \$22/ton (tipping fee at landfill); Amador Transfer Station is $\$ 24.80 /$ ton (tipping fee at landfill); Corralitos Landfill is $\$ 18.60 /$ ton (75\% of tipping fee). 
Table B-3: MSW Waste-to-Energy Results

\begin{tabular}{|c|c|c|c|c|}
\hline Waste Source(s) & Amador TS & Corralitos LF & Amador TS & Corralitos LF \\
\hline Technology & Combustion & Combustion & Gasification & Gasification \\
\hline Plant Size & 26.6 MW & $33.2 \mathrm{MW}$ & $35.2 \mathrm{MW}$ & $43.9 \mathrm{MW}$ \\
\hline Feedstock Amount & 241,487 tons/yr & 301,247 tons/yr & 241,487 tons/yr & 301,247 tons/yr \\
\hline Total Plant Cost & $\$ 2893.0 / \mathrm{kW}$ & $\$ 2767.9 / \mathrm{kW}$ & $\$ 2958.0 / \mathrm{kW}$ & $\$ 2830.1 / \mathrm{kW}$ \\
\hline Capital Cost & $\$ 2893.0 / \mathrm{kW}$ & $\$ 2767.9 / \mathrm{kW}$ & $\$ 2958.0 / \mathrm{kW}$ & $\$ 2830.1 / \mathrm{kW}$ \\
\hline Sales Tax & $\$ 0.0 / \mathrm{kW}$ & $\$ 0.0 / \mathrm{kW}$ & $\$ 0.0 / \mathrm{kW}$ & $\$ 0.0 / \mathrm{kW}$ \\
\hline Fixed O\&M Cost & $\$ 92.1 / \mathrm{kW}$ & $\$ 88.8 / \mathrm{kW}$ & $\$ 120.3 / \mathrm{kW}$ & $\$ 103.4 / \mathrm{kW}$ \\
\hline Variable O\&M Cost & $-1.8 \$ / k W h$ & $-1.0 \$ / \mathrm{kWh}$ & $-1.7 \$ / \mathrm{kWh}$ & $-1.1 \Phi / \mathrm{kWh}$ \\
\hline Feedstock Cost & $-\$ 24.79 /$ ton & $-\$ 18.61 /$ ton & $-\$ 24.79 /$ ton & $-\$ 18.61 /$ ton \\
\hline SIR & 2.2 & 2.1 & 1.8 & 1.9 \\
\hline Simple Payback & 6.0 years & 6.4 years & 7.1 years & 6.9 years \\
\hline Internal Rate of Return (IRR), No Financing & $18.58 \%$ & $17.85 \%$ & $16.21 \%$ & $16.68 \%$ \\
\hline
\end{tabular}

These scenarios show that a number of options are available to WSMR. Combustion of WSMR waste with Amador Transfer Station waste is the most economical, but not significantly so over the other options. Other options may be more desirable to reduce air emissions, generate more power, or because the waste is readily available, and so should still be considered.

The scenarios assume that all waste collected or processed at these facilities will be available, at the indicated price assumption. These total amounts may not be available, and these revenues may not be available, possibly resulting in less attractive options. Communication with the waste handlers and landfill owners is necessary to determine the best option.

\section{Biomass and Waste-to-Energy: Next steps}

Using MSW to generate electricity is a potentially viable option for WSMR and should be pursued. The following steps must occur to implement a waste-to-energy plant.

Quantify the waste that is realistically available. The regional waste collection entities need to be approached to characterize potential waste quantities and prices. This may be the determining factor as to which option is pursued. 
Find a location for the plant. A site is needed that is large enough for the equipment, feedstock storage, and access, can be accessed by trucks for feedstock delivery (both on site and off site), and can be connected to the site electric grid.

Interview developers to assess potential interest in developing projects on DoD land. Once the development interest and feedstock source for the energy are secured, plans can proceed with the design and final economic calculations.

It is not recommended to pursue other options at this time.

\section{Biomass and Waste-to-Energy References}

Aabakken, J. "Power Technologies Energy Data Book.” National Renewable Energy Laboratory. Fourth Edition. NREL/TP-620-39728. August 2006.

Anderson, David, WSMR Land Manager. Personal communications. August 2008.

Bain, RL, et al. "Biopower Technical Assessment: State of the Industry and Technology." National Renewable Energy Laboratory. NREL/TP-510-33123. March 2003.

Burke, Dennis. “Dairy Waste Anaerobic Digestion Handbook.” Encyclopedia of Animal Science. Environmental Energy Company. June 2001. http://www.makingenergy.com/Dairy\%20Waste\%20Handbook.pdf.

City of Alamagordo. “Landfill.” http://ci.alamogordo.nm.us/coa/publicworks/landfill.htm. Accessed June 2008.

City of Las Cruces. "Fabrication and Repair Services Price Agreement, Bid \#07-08-142.” South Central Solid Waste Authority. September 2007. http://www.lascruces.org/financial_srvs/Purchasing/bids/downloads/B07-08-142/07-08142\%20FABRICATION\%20\%20REPAIR\%20final.pdf.

City of Las Cruces. "South Central Solid Waste Authority.” http://www.lascruces.org/utilities/solid\%20waste/scswa.shtm. Accessed June 2008.

Database of State Incentives for Renewables and Efficiency. "New Mexico Incentives for Renewables and Efficiency." http://www.dsireusa.org/library/includes/map2.cfm?CurrentPageID=1\&State=NM\&RE=1\&EE=1. Accessed June 2008.

Energy Information Administration. "Average Heat Content of Selected Biomass Fuels.” http://www.eia.doe.gov/cneaf/solar.renewables/page/trends/table10.html. Accessed September 2007.

Environmental Protection Agency Landfill Methane Outreach Program. http://www.epa.gov/lmop/proj/index.htm. Accessed October 2007.

Gallagher, Paul, et al. “Biomass from Crop Residues: Cost and Supply Estimates.” United States Department of Agriculture, Office of the Chief Economist. February 2003.

http://www.usda.gov/oce/reports/energy/AER819.pdf. 
Gray, Alicia, WSMR Public Utilities Specialist. Personal communications. June 2008.

Hahn, Christopher, WSMR Chief of Utilities. Personal communications. June 2008.

Haq, Zia. “Biomass for Electricity Generation.” Energy Information Administration. July 2002. http://www.epa.gov/solar/pdf/haq_apr20.pdf.

IEA Energy Technology Essentials. "Biomass for Power Generation and CHP.” http://www.iea.org/textbase/techno/essentials3.pdf. January 2007.

Janda, David, WSMR Energy Manager. Personal communications. June 2008.

Lamar, David, Integrated Environmental Technologies, LLC. Personal communications. October 2007.

McDaniel, Edward, Engineer. ES Alternatives. Personal communications. March 2008.

Pereira, Carol, WSMR Realty Specialist. Personal communications. June 2008.

Research Reports International. “The Use of Biomass for Power Generation in the U.S.” July 2007.

Shanahan, J.F., et al. “Crop Residues for Livestock Feed.” Colorado State University Extension Agriculture. http://www.ext.colostate.edu/pubs/CROPS/00551.html. September 1998.

Smith, Carl Benjamin, et al. "Lesser Known Energy Sources: A Study of Biogas and Tire Based Fuel.” Lockheed Martin. September 2007. http://www.aeecenter.org/DivisionNewsletters/AREDI/Fall07/biogas-tires.pdf.

Soil Quality National Technology Development Team. “Crop Residue Removal for Biomass Energy Production: Effects on Soils and Recommendations.” National Resources Conservation Service. http://soils.usda.gov/sqi/management/files/sq_atn_19.pdf. August 2006.

State Energy Conservation Office. "Energy Crops for Fuel.”

http://www.seco.cpa.state.tx.us/re biomass-crops.htm. Accessed February 2008.

Stone, Robert, et al. "Universal Soil Loss Equation (USLE).” Ministry of Agriculture, Food and Rural Affairs. http://www.omafra.gov.on.ca/english/engineer/facts/00-001.htm\#tab2. May 2000.

United States Department of Agriculture Forest Service. "Forest Inventory \& Analysis Mapmaker Program on Timber Products Output Studies.” http://www.fia.fs.fed.us/program-features/tpo/. Accessed June 2008.

United States Department of Agriculture National Agricultural Statistics Service. http://www.nass.usda.gov/Data_and_Statistics/Quick_Stats/. Accessed June 2008.

United States Environmental Protection Agency. Turning a Liability into an Asset: A Landfill Gasto-Energy Project Development Handbook. Landfill Methane Outreach Program. September 1996. 
Walsh, Marie E., et al. "Biomass Feedstock Availability in the United States: 1999 State Level Analysis.” Oak Ridge National Laboratory. January 2000.

http://bioenergy.ornl.gov/resourcedata/index.html. 
APPENDIX C

Analysis of Geothermal Plant Opportunities 
Renewable Energy Opportunities at White Sands

Missile Range, New Mexico

Pacific Northwest National Laboratory, Sept 2008 


\section{Appendix C: Analysis of Geothermal Power Plant Opportunities}

\section{Geothermal Power Plant Technology}

Geothermal power plants use steam from hot water reservoirs found deep below the Earth's surface. The steam rotates a turbine that activates a generator, producing electricity. There are three commercial types of geothermal power plants used to generate electricity (dry steam, flash steam, and binary cycle), and several newer technologies are entering the marketplace (hot dry rock and engineered geothermal systems). The type of plant depends on the state of the fluid (whether it is steam, hot water, or mixed) and its temperature.

$\checkmark$ Dry Steam power plants use underground steam piped directly from wells to the power plant, where it passes through separators to remove small particles before it is directed into a turbine/generator unit. There are only two known underground resources of steam in the United States: The Geysers in northern California and Yellowstone National Park in Wyoming. The only dry steam plants in the country are at The Geysers.

$\checkmark$ Flash Steam power plants use geothermal resources that produce high-temperature hot water or a combination of steam and hot water. This very hot water (reservoirs greater than $360^{\circ} \mathrm{F}$ or $182^{\circ} \mathrm{C}$ ) flows up through wells in the ground under its own pressure. As it flows upward and the pressure decreases, some of the hot water boils (flashes) into steam. The steam is then separated from the water and used to power a turbine/generator. Any leftover water and condensed steam are injected back into the reservoir, making this a sustainable resource. Depending on the temperature resource, it may be possible to use a second flash tank where more steam at a lower pressure is separated for generation (double flash plant).

$\checkmark$ Binary Cycle power plants utilize a second fluid in a closed cycle to operate the turbine, instead of direct geothermal steam. These plants operate on water at lower temperatures of about $225^{\circ}$ to $360^{\circ} \mathrm{F}\left(107^{\circ}\right.$ to $\left.182^{\circ} \mathrm{C}\right)$. The heat from the hot water is used to boil a working fluid, usually an organic compound with a low boiling point. The working fluid is vaporized in a heat exchanger and used to turn a turbine. The water is then injected back into the ground to be reheated. The water and the working fluid are kept separated during the whole process, so there is minor or no contamination. The advantage of the binary cycle plant is that it can operate with lower temperature water by using working fluids that have an even lower boiling point than water. Binary power plants are available in smaller scales such as 200 to $1,000 \mathrm{~kW}$.

$\checkmark \quad$ Hot Dry Rock (HDR) geothermal production utilizes high temperature rocks found deeper (several kilometers) below the surface by pumping high-pressure water down a borehole into a heat zone. The water captures the heat of the rock by traveling through fractures until it is forced out a second borehole and used to generate electricity. Once the water has cooled, it is pumped back underground to heat up again. This process is most easily utilized in locations with natural geothermal systems with existing cracks or pore spaces.

$\checkmark \quad$ Engineered or Enhanced Geothermal Systems (EGS) are similar to HDR systems. In locations where there are few cracks and connected pore spaces, or little to no cracks or connectivity, cracks can be created or enhanced. The advantage of HDR or EGS is that geothermal resources can be captured for production in non-tectonically active regions. This technology is still very new and expensive. 


\section{Geothermal Energy Analysis Approach}

In the 2004 DoD Renewable Energy Assessment, the Navy's Geothermal Office was responsible for the DoD geothermal power assessment. That task was subcontracted to Innovative Technical Solutions, Inc. (ITSI). The Navy and ITSI ranked installations based on their assessment of potential. The utility grade geothermal assessment included 18 installations identified by the DoD. Of those installations, five sites were found to have high potential for utility grade systems.

Funding limited the number of sites that could be inspected and assessed. ITSI visited some locations and collected information through site inspections (for things like hot springs), field measurements and review of temperature readings from water well drilling logs. This information was compiled in site reports and used to recommend further analysis, typically the drilling of test wells to measure temperature and assess subsurface conditions. Drilling test wells is the next in a progression of steps and is generally very expensive, on the order of $\$ 1$ million per well.

WSMR was found to be one of five sites with high potential for the occurrence of utility-grade geothermal systems according to the 2003 DoD study.

The contiguous tract of land that comprises the White Sands Missile Range (WSMR), Holloman AFB, and Fort Bliss encompasses a large portion of the Rio Grande Rift, a tectonically active province in which high heat flow, Quaternary faulting, and moderatetemperature geothermal resources have been discovered and exploited. Based on the forced convection geothermal occurrence model, at least one prospective site on WSMR, Bear Peak, was identified by a self-potential (SP) survey during field investigations. Variations on this model are used to describe the Rincon, Radium Springs, and Tortugas Mountain geothermal systems west of WSMR. All three have strong SP anomalies similar to the anomaly identified at Bear Peak. The probability that direct-use geothermal resources exist at Fort Bliss, Texas, is high. Mapping, temperature gradient and core drilling, soil gas sampling, and geophysics have been used to outline a moderate-temperature resource from the McGregor Range/Hueco Tanks geothermal system at Fort Bliss. Although these temperatures are moderate, efficiencies in binary geothermal power plants have increased to the point that the utility-grade potential of the entire WSMR/Holloman/Fort Bliss region is considered high.

Bear Peak is located north of the WSMR cantonment area along the eastern flank of the San Andres Mountains. The McGregor Range is located in the central portion of Ft. Bliss, on the New Mexico side of the border (ITSI 2003).

We utilized the information available from the DoD study, in addition to other readily available sources, to determine if the following conditions exist, which demonstrate utility grade geothermal potential:

$\checkmark$ Existing power plant operation or developer activity

$\checkmark$ One or more wells tested with temperatures in excess of $212^{\circ} \mathrm{F}\left(100^{\circ} \mathrm{C}\right)$ logged downhole (at depths less than 3,000 m)

$\checkmark$ Demonstrated high fluid flow rates on the order of 1,000 gallons per minute per MW

$\checkmark$ Heat flow rates greater than $80 \mathrm{~mW} / \mathrm{m}^{2}$ (milliWatts per square meter)

$\checkmark$ Other exploration data and information available $\left(>=212^{\circ} \mathrm{F}\left(100^{\circ} \mathrm{C}\right)\right.$ not proven) 
Since the 2003 DoD geothermal assessment, additional R\&D has been done on other geothermal development techniques that may be applicable to additional installations. If any new information is available, we attempt to interpret this new information for economic applicability.

\section{Geothermal Resource Characterization}

For the purposes of this evaluation, WSMR and Ft. Bliss were considered together. This is because both bases lie within the same tetonic province, and because of the proximity of the installations to each other and to the existence of a high temperature reading from the McGregor Range/Hueco Tanks geothermal system at Fort Bliss.

Geothermal resources include hot springs, geysers, and underground resources of pressurized water and steam accessible via wells, as well as dry steam, hot water, hot dry rocks, and low-temperature geothermal heat. A known geothermal resource area (KGRA) is an area in which the geology, nearby discoveries, competitive interests, or other indicators would show a potential for extraction of geothermal steam or associated geothermal resources are good enough to warrant consideration.

WSMR and Ft. Bliss lies within a known or potential geothermal resource area (KGRA). Direct use activities that are currently occurring include greenhouse, space heating, aquaculture, and districting heating; all in use in Las Cruces area (INL 2003). As was mentioned before, WSMR and Ft. Bliss lie within the southern Rio Grande rift, a tectonically active north-south trending zone of high heat flow, Quaternary faulting, and moderate-temperature geothermal resources. See Figure C-1 for reference.

For commercial use, it is necessary to have a geothermal reservoir capable of providing hydrothermal (hot water and steam) resources with sufficiently high flow rates. Successful geothermal electrical power generation requires fluid flow rates equal to or greater than 1,000 gpm (gallons per minute) per MW (megawatt). For example, $1.5 \mathrm{MW}$ of electricity at a reservoir temperature of $300^{\circ} \mathrm{F}$ requires a flow rate of about 1,000 gpm, or about 1,029,000 bbs/month (McKenna, USACE).

Geothermal plants operate in regions with high heat flow rates. Heat flow values above $80 \mathrm{~mW} / \mathrm{m}^{2}$ (milliWatts/square meter) are considered characteristic of a viable geothermal resource. Productive heat flows are generally greater than $150 \mathrm{~mW} / \mathrm{m}^{2}$ (Blackwell et al. 2003). According to the 2003 DoD study, the heat flow rates near WSMR/Ft. Bliss are varied, but show promise (ITSI 2003):

In general, heat flow in the Rio Grande rift is greater than $80 \mathrm{~mW} / \mathrm{m}^{2}$, with values in excess of $100 \mathrm{~mW} / \mathrm{m}^{2}$ concentrated along the axis of the rift (Blackwell et al., 1991). Very high heat flow in excess of $200 \mathrm{~mW} / \mathrm{m}^{2}$ is observed locally in proximity to large normal faults and caldera boundaries; these structures may facilitate migration of hydrothermal fluids from deeper reservoirs to upper crustal levels (Reiter et al., 1991).

This information indicates heat flow rates in select areas near WSMR and Ft. Bliss could be sufficient for geothermal electricity generation. 


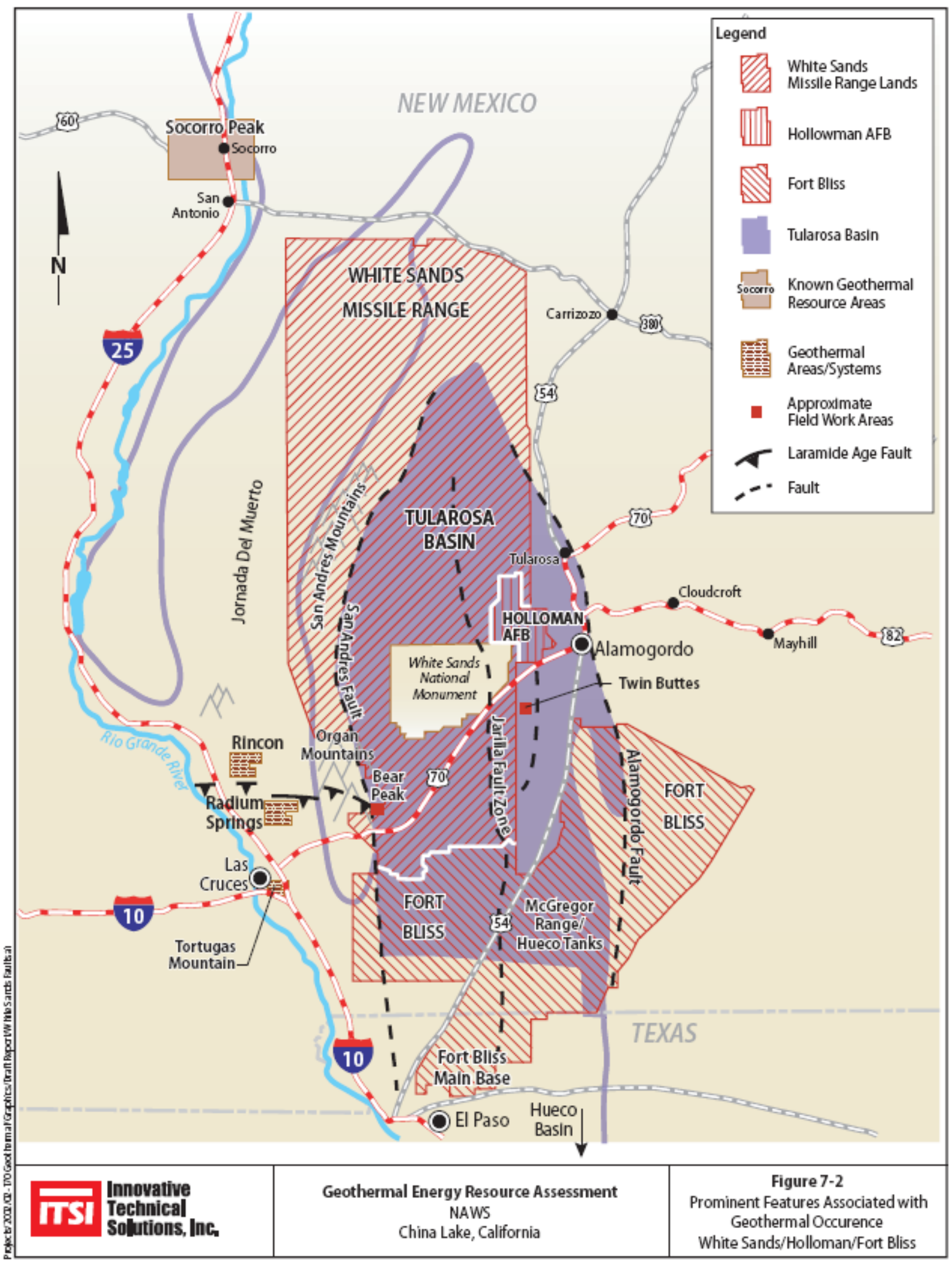

Figure C-1: Geothermal Map in the WSMR/Ft. Bliss Region from the DoD Geothermal Assessment (ITSI 2003) 


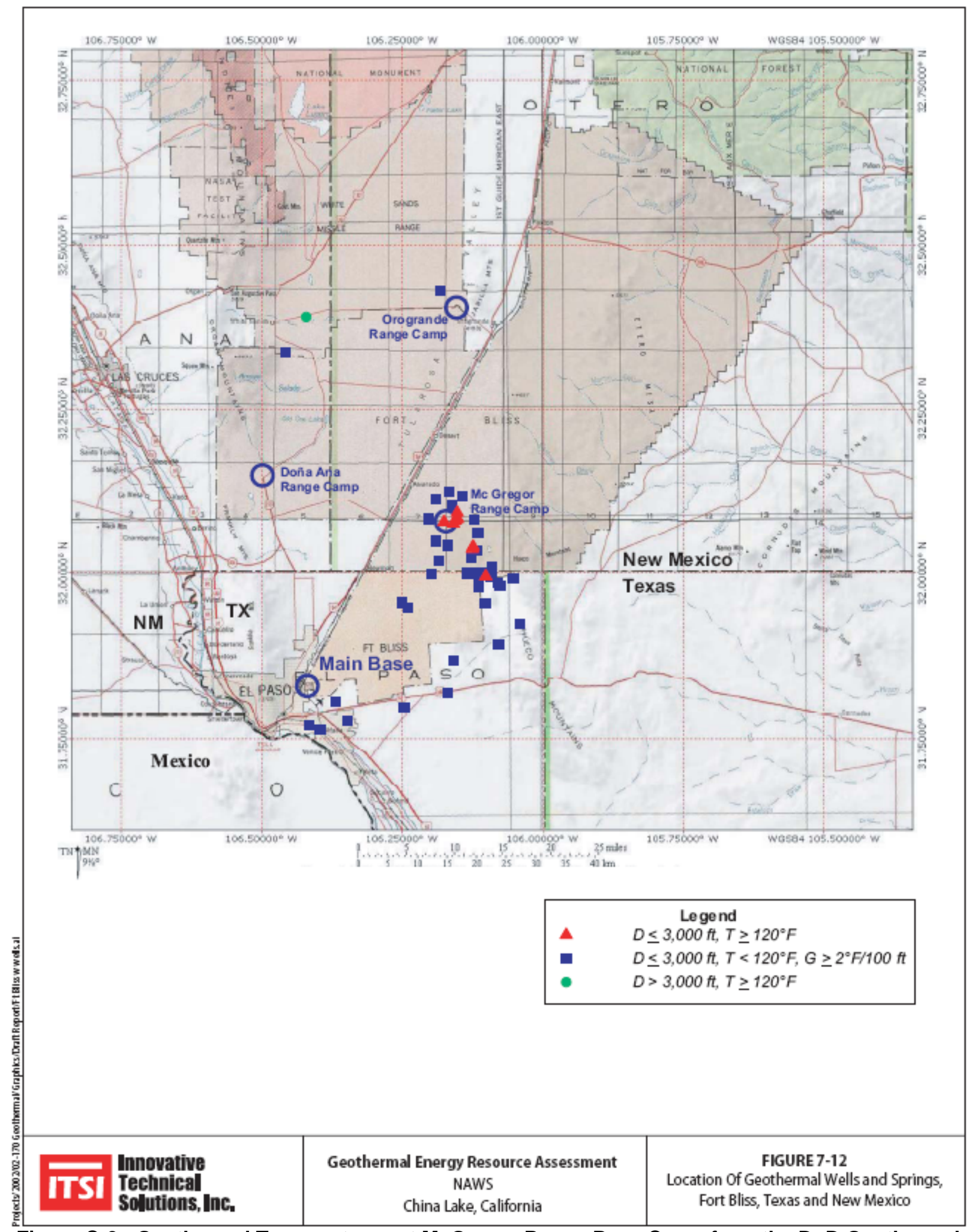

Figure C-2: Geothermal Temperatures at McGregor Range Base Camp from the DoD Geothermal Assessment (ITSI 2003) 
Utility grade geothermal energy requires temperatures in excess of $212^{\circ} \mathrm{F}\left(100^{\circ} \mathrm{C}\right)$ at depths less than $3 \mathrm{~km}$. The Geothermal Temperature at Depth Map for the Continental United States shows 100$175^{\circ} \mathrm{C}$ at $3 \mathrm{~km}$ (INL 2005). According to the previous DoD renewable energy study, well MG-16, approximately $4 \mathrm{mi} \mathrm{SE}$ of McGregor Range Camp, recorded $173^{\circ} \mathrm{F}\left(78.3^{\circ} \mathrm{C}\right)$ at 1,500 feet $(457 \mathrm{~m})$. Two other wells (MG-14 and N-9) indicated Temperatures $>160^{\circ} \mathrm{F}$ at 1,000 feet or less are within 2 mi of the camp (ITSI 2004).

Temperature-gradient measurements within approximately 100 miles of WSMR, Holloman AFB and Fort Bliss are available from approximately 400 wells... Temperature gradients range widely, from 0 to $464^{\circ} \mathrm{C} / \mathrm{km}$, with most ranging between 20 and $50^{\circ} \mathrm{C} / \mathrm{km}$. A significant fraction of wells have gradients above $50^{\circ} \mathrm{C} / \mathrm{km}$, but these wells are primarily limited to the areas of known geothermal prospects, including the Hueco Tanks in the south, prospects to the southwest near Las Cruces, and prospects to the northwest near Socorro. The geographic pattern to these gradients is similar to that observed below from geothermometry data, with on-site wells being relatively low (below $50^{\circ} \mathrm{C} / \mathrm{km}$, and gradients increasing off-site to the west, south, and northwest. Temperature-gradient measurements for wells located on or near Holloman ... fall within a narrow range of 29 to $43^{\circ} \mathrm{C} / \mathrm{km}$. These gradients are expected for the Holloman area, which is east of WSMR and more distant from the known areas of higher heat flow centered on the Rio Grande Valley (ISTI 2003).

Temperature gradient logs show uncorrected $340^{\circ} \mathrm{C} / \mathrm{km}$ for MG-16 and $180^{\circ} \mathrm{C} / \mathrm{km}$ for MG-14 (ITSI 2003). See Figure C-2 for the location of the McGregor Range Base Camp. Several temperatures and gradients found are sufficient at shallow enough depths for geothermal electricity generation using current technology. The temperatures and gradients are variable at different locations. Further geologic studies and drilling is necessary to know the actual temperature at depth before proceeding with a project.

There is uncertainty regarding the source of the geothermal anomalies. According to the DoD geothermal study from 2003 (ITSI 2003):

Morgan et al. (1991) propose that "forced convection" may be driving the upwelling of thermal waters at Hueco Tanks and, if so, then subsurface faults may further concentrate and localize fluid flow. Although there is a high likelihood that direct-use geothermal resources are present at Fort Bliss, the utility-grade geothermal for high grade production has not been fully developed; however, improved efficiencies in binary plant technology may make Hueco Tanks/McGregor Range geothermal system a high potential region .

The report goes on to explain that, if non-magmatic geothermal anomalies in the Rio Grande Rift result from forced convection processes, then there is probably no potential for direct electrical generation. Further exploration of the Hueco Tanks/McGregor Range geothermal system is warranted to determine if sufficient resources exist for binary plant geothermal electricity generation.

Geothermal electrical generation plants are currently operating in Alaska, California, Nevada, Utah, and Hawaii with proposed projects in Arizona, Oregon, Idaho, New Mexico, Texas, Washington, and Wyoming. Currently no geothermal power plants in NM generating electricity. Three geothermal electric binary units totaling $750 \mathrm{~kW}$ are located at Burgett Geothermal Greenhouses in the Lightning Dock KGRA; but they are currently offline (GEA 2006). 


\section{Geothermal Power Plants: Economic and Other Analysis Parameters}

This assessment considered the current federal wind incentive-a 2.0\$/kWh renewable energy production credit and 5-year accelerated depreciation. Because the potential project is currently being targeted for construction in New Mexico, only New Mexico state incentives were considered. New Mexico incentives for geothermal include a sales tax exemption and a renewable energy portfolio standard (RPS) (DSIRE 2007). For the sales tax exemption, we are assuming that the assembly of the renewable energy system would meet the exemption requirements. This assumption would need to be checked carefully with the State of New Mexico. There is also a possibility that a geothermal project could benefit from the sale of renewable energy credits (RECs) to utilities needing to meet New Mexico’s Renewable Portfolio Standard requirements.

The analysis assumed that electricity transmission lines located on or near the potential geothermal development area would be available to transmit power without substantial additional investment.

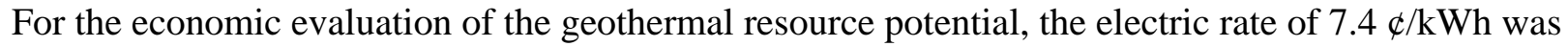
utilized. The economics were also run to determine the minimum price per $\mathrm{kWh}$ required to earn a sufficient IRR for independent power producers.

\section{Installed Costs of Technology}

Geothermal power costs are influenced by capital costs for land, drilling, and the physical plant. The analysis also needs to consider the cost of operation and maintenance (O\&M), the amount of power generated, and the market value of the power. Capital costs range from $\$ 1,500$ to $\$ 4,000$ per installed $\mathrm{kW}$. Capital costs for flash steam plants tend to be less expensive than binary plants. Plant life spans are typically between 30 and 45 years.

Capital costs include:

$\checkmark$ Initial development work: land leasing, exploration, permitting, test well costs

$\checkmark$ Infrastructure: roads, water supply, utilities

$\checkmark$ Well field drilling: production wells in addition to already drilled confirmation wells

$\checkmark$ Steam and brine gathering system: pipes and brine separation equipment

$\checkmark$ Power plant: physical equipment for energy conversion, including substation

$\checkmark$ Interconnection: link of the power plant substation to the transmission corridor

$\checkmark$ Soft costs: developers' fees, overhead, financing costs, legal fees, etc.

Geothermal wells are drilled to depths of 200 to 1,500 meters for low and medium temperature systems. For high temperature systems, wells are drilled 700 to 3,000 meters deep. Each well costs \$1 million to \$4 million to drill, and a geothermal field may consist of between 10 and 100 wells.

Operating plants at over $90 \%$ capacity will result in higher O\&M costs. Larger plant size means

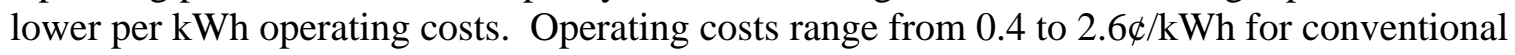
geothermal power plants.

According to existing data, WSMR/Ft. Bliss area seems to have elevated temperatures at economic depths (less than 3,000 $\mathrm{m}$ ) and sufficient heat flow rates for geothermal energy production. The 
economic analysis was run with the optimistic assumption of $340^{\circ} \mathrm{C} / \mathrm{km}$ for the temperature gradient and a temperature of $173^{\circ} \mathrm{F}\left(78.3^{\circ} \mathrm{C}\right)$ at 1,500 feet $(457 \mathrm{~m})$ based on the recorded well results from MG-16, approximately 4 mi SE of McGregor Range Camp at Ft. Bliss. See Table C-1 below for all other economic assumptions.

Table C-1: Performance, Cost, and Economic Characteristics

\begin{tabular}{|c|c|}
\hline Assumed temperature at $457 \mathrm{~m} \&$ gradient & $78.3^{\circ} \mathrm{C}, 340^{\circ} \mathrm{C} / \mathrm{km}$ \\
\hline Capacity Factor & $96 \%$ \\
\hline Technology Type & Binary \\
\hline Project Size & $15 \mathrm{MW}$ \\
\hline Estimated Annual Energy Production & $126,144 \mathrm{MWh}$ \\
\hline Average Cost of Energy & $7.4 \$ / \mathrm{kWh}$ \\
\hline Total Capital Cost & $\$ 4567 / \mathrm{kW}$ \\
\hline
\end{tabular}

Further details on the analysis methodology and the economic and incentive parameters are documented in Appendix A of this report.

\section{Findings: Geothermal Power Plant Opportunities}

The resource analysis for WSMR found high potential for utility grade geothermal electricity production, with the potential for a cost-effective project identified. The biggest factor in the capital cost is the number of expensive wells required to produce adequate hot water and steam resources at sufficient flow rates. The resource estimations need to be confirmed with actual well data and further geological studies.

The ECIP analysis based upon electricity valued at 7.4థ/kWh yielded a payback period of 10.32 years, with an SIR of 1.0. Under the IPP scenario, the current electricity rate of $7.4 / \mathrm{kWh}$ yields a sufficiently high IRR at $10.32 \%$ (a 10\% IRR is the minimum for IPP to be interested).

This assessment, which is focused on utility-scale electricity generation, did not examine the potential for direct use applications of geothermal resources such as space heating, aquaculture, and industrial processes.

\section{Geothermal Power Plants: Next Steps}

The economic analysis for geothermal electricity at WSMR relied upon many assumptions. The resource data for this assessment is based on the most optimistic well temperature and temperature gradient found at Ft. Bliss from the previous DoD geothermal study. Further geological studies including the drilling of test wells would need to accurately determine the geothermal resource.

Because the geothermal resource proximate to WSMR is high, further action that should be taken to determine the realities of the geothermal resource potential. Further exploration of the Hueco Tanks/McGregor Range geothermal system and Bear Park anomaly is warranted. The DoD geothermal renewable energy assessment recommended the following in 2003: 
Based on the geothermal occurrence models discussed in this report and the results of SP work east of Bear Peak, additional exploration targets for geothermal development should be investigated in the vicinity of WSMR and Fort Bliss along active normal faults that bound the deeper, western half of the Tularosa Basin. Minimally, the Bear Peak SP anomaly as well as several other similar targets not investigated during this project should be evaluated.

Suggested additional areas include the Mockingbird Gap region, between Mockingbird and Little Burro Mountains, about 10 miles $S$ of the Trinity site in north central WSMR. Mockingbird Gap may be a releasing bend as evidenced by fault locations and the geometry of the ranges. Additional field reconnaissance work plus possibly a CO2 soil gas survey is recommended. According to Highsmith (R. P. Highsmith, Chemex Labs, Sparks, NV, personal communication 2003), soil gas surveys have proven to be extremely effective for evaluating suspected faults or fractured channelways where upward-flowing fluids are locally concentrated. Although late Quaternary activity of the San Andres fault and Organ Mountains fault (i.e. Bear Peak anomaly sits on San Andres Fault) is well documented, the activity of the Jarilla Fault zone currently is not known. This target area should be investigated, perhaps with geophysical surveys.

These recommendations still apply today. The potential for geothermal resources of sufficient quality are found on and near Ft. Bliss and WSMR, but additional work is required to further characterize the potential. WSMR may want to consider partnering with Ft. Bliss to further explore the potential for geothermal electricity.

\section{Geothermal Power Plant References}

Berkman, Frederick E. and Christopher J. Carroll. October 2007. Interpretive Geothermal Heat Flow Map of New Mexico. New Mexico Geological Survey, Department of Natural Resources. Co-funded by the Governor's Energy Office (contract C900537) and the Department of Natural Resources Severance Tax Operational Fund. http://geosurvey.state.co.us/portals/0/Map\%20Series\%2045\%20Plate\%201,\%20Interpretive\%20Geother mal\%20Heat\%20Flow\%20Map\%20of\%20New Mexico\%2044x32.pdf

Blackwell, David D. et al. 2003. Geothermal Resource Analysis and Structure of Basin and Range Systems, Especially Dixie Valley Geothermal Filed, Nevada. Department of Geological Sciences Southern Methodist University. June 2003. http://www.osti.gov/energycitations/servlets/purl/813485-smnwbs/native/813485.PDF

California Energy Commission. 2003. Renewable Resources Development Report. California Energy Commission Report. November 2003. http://www.energy.ca.gov/reports/2003-11-24_50003-080F.PDF

Campbell, R.G., and M.M. Hatter. 1991. Design and operation of a geopressured geothermal hybrid cycle power plant: Final report vol. I, 180 p. and vol. II, 172. Eaton Operating Company, Inc. and United States Department of Energy, The Ben Holt Co., DOE contract DE-ACO785ID12578.

Office of Energy Efficiency and Renewable Energy (EERE). 2005. Appendix F - GPRA05 Geothermal Technologies Program Documentation. Projected Benefits of Federal Energy Efficiency 
and Renewable Energy Programs (FY 2005-FY 2050).

http://www1.eere.energy.gov/ba/pdfs/gpra_fy05_appendix_f.pdf

Geothermal Energy Association (GEA) for the U.S. Department of Energy. Geothermal Resource Development Needs in New Mexico. By Daniel J. Fleischmann. September 2006. http://www.geo-energy.org/publications/reports/NewMexicoGeothermalReportSept06.pdf

GeothermEx, Inc. Public Interest Energy Research Report. New Geothermal Site Identification and Qualification. California Energy Commission. April 2004. http://www.geothermex.com/CECPIER Report New Geothermal Site Identification and Qualification.pdf

Hance, Cédric Nathanaël. Factors Affecting Costs of Geothermal Power Development. Geothermal Energy Association. August 2005. http://www.geoenergy.org/publications/reports/Factors\%20Affecting\%20Cost\%20of\%20Geothermal\%20Power\%20 Development\%20-\%20August\%202005.pdf

Idaho National Laboratory (INL). 2003. New Mexico Geothermal Resources. Publication No. INEEL/MISC-2002-395 Rev. 1. November 2003. http://geothermal.inl.gov/maps/nm.jpg

Idaho National Laboratory (INL). 2005. Temperature at Depth Maps for the Continental United States. Estimated Temperature at 3 Kilometers. 4/12/2005. http://geothermal.id.doe.gov/maps/

Innovative Technical Solutions (ITSI). 2003. Geothermal Energy Resource Assessment on Military Lands. Prepared for NAWS China Lake. Contract No. N68936-02-R-023. October 2003. http://www.geothermal.org/GEO_0001.PDF

Innovative Technical Solutions (ITSI). 2004. Geothermal Energy Resource Assessment on Military Lands. Proceedings, Twenty-Ninth Workshop on Geothermal Reservoir Engineering. Stanford University, Stanford, California, January 26-28, 2004. SGP-TR-175.

http://pangea.stanford.edu/ERE/pdf/IGAstandard/SGW/2004/Sabin.pdf

Joost J. Brasz, Bruce P. Biederman, and Gwen Holdmann. Power Production from a Moderate Temperature Geothermal Resource. GRC Annual Meeting September 25-28th, 2005; Reno, NV, USA. http://www.yourownpower.com/Power/grc\%20paper.pdf

McKenna, Jason R. 2006. U.S. Army Corps Engineer Research \& Development Center. Increasing Electrical Power Capacity for Military Applications. U.S. Army Corps Engineer Research \& Development Center. http://www.smu.edu/geothermal/Oil\&Gas/Mckenna_Army\%20Corps.pdf

MIT-led interdisciplinary panel. The Future of Geothermal Energy: Impact of Enhanced Geothermal Systems (EGS) on the United States in the 21st Century. DOE. 2006

http://geothermal.inl.gov/publications/future_of_geothermal_energy.pdf

NOAA Satellite and Information Center. Thermal Springs National Geophysical Data Center. Thermal Springs of the United States. http://map.ngdc.noaa.gov/website/seg/hot_springs/viewer.htm 
Petty, Susan. Engineering Geothermal Systems in Oil \& Gas Reservoirs. Presentation at the Southern Methodist University (SMU) Geothermal Lab conference on Geothermal Energy Utilization Associated with Oil and Gas Development. June 12 and 13, 2007.

http://www.smu.edu/geothermal/Oil\&Gas/2007/Petty_Susan\%20Engineering\%20Geothermal\%20Sy stems\%20in\%20Reservoirs.pdf

Rafferty, Kevin. Geothermal Power Generation: A Primer on Low-temperature, Small-scale Applications. Geo-Heat Center. January 2000. http://geoheat.oit.edu/pdf/powergen.pdf

Sares, Matthew A. 2007. Assessing New Mexico’s Geothermal Potential to Generate Electricity. New Mexico Geological Survey. October 10, 2007.

http://geosurvey.state.co.us/pubs/powerpoint/geothermal_10_2007/Sares_GthmlCO_InvForum102007Final.swf

Shibaki, Masashi. Geothermal Energy for Electric Power. A Renewable Energy Policy Project (REPP) Issue Brief. December 2003.

http://www.crest.org/articles/static/1/binaries/Geothermal_Issue_Brief.pdf

Southern Methodist University Geothermal Lab. Geothermal Map of the United States (heat flow map). 2004.

http://www.smu.edu/geothermal/heatflow/geothermal_all_us_clipped_150dpi_pagesize_legend.gif

WGA (Western Governors Association) Geothermal Task Force. Near-Term Geothermal Resource Assessment. WGA. November 3, 2005. http://www.geo-

energy.org/information/developing/WGA\%20GEOTHERMAL\%20TASK\%20FORCE\%20RESOUR CE\%20ASSESSMENT\%20NOV\%203\%2020051.pdf 
Renewable Energy Opportunities at White Sands

Missile Range, New Mexico

Pacific Northwest National Laboratory, Sept 2008 


\section{APPENDIX D}

\section{Analysis of Ground Source Heat Pump Opportunities}


Renewable Energy Opportunities at White Sands

Missile Range, New Mexico

Pacific Northwest National Laboratory, Sept 2008 


\section{Appendix D: Analysis of Ground Source Heat Pump Opportunities}

\section{Ground Source Heat Pump Technology}

Ground source heat pumps (GSHPs) use the stable temperatures of the Earth and groundwater to improve the coefficient of performance of heating and cooling applications for buildings. Common GSHP configurations include open-loop, horizontal closed-loop, and vertical closed-loop.

$\checkmark$ Open-loop systems use open wells or bodies of water as direct heat transfer mediums to provide cool temperatures in the summer and warm temperatures in the winter. Heat transfer is only needed once, at the building, because groundwater is used directly, and the limited drilling and trenching needed results in a lower first cost.

$\checkmark$ Closed-loop systems use heat transfer fluid inside a sealed pipe to exchange heat with the earth. Closed-loop systems have lower pumping requirements and are more efficient than open-loop systems. However, soil type and moisture content is more critical to the performance of these systems, and the trenching and drilling significantly increases first cost. Horizontal loops require trenching, so that all the piping lies at the same depth in the ground.

$\checkmark$ Vertical closed-loop GSHPs are deployed in vertical boreholes, and are the most efficient configuration.

GSHPs are applicable in almost any building with both heating and cooling. They can be used in buildings as small as 100 square feet, or up to a million square feet. Multiple GSHPs can be used in a single building to meet the load, or the same ground loop can be shared between buildings.

To install GSHPs at a building, the surrounding area will have certain prerequisites, depending on the type of GSHP. Open-loop GSHPs need a water source and sink. The source can be a well or open body of water. To replenish this water, the sink can be a secondary well, the open body of water used as the source, another body of water, or a storm drain. Water volume requirements depend on the size of GSHP installed, but typically between 1.5 and 3.0 gallons per minute are needed per cooling ton. This greatly affects the feasibility of open-loop systems in some areas, as do local codes and regulations. Many locales do not want to risk groundwater depletion or contamination.

Horizontal closed-loop GSHPs have a different limiting factor: sufficient land area. The heat transfer for these systems occurs in pipes laid in trenches that are 100 to 400 feet long per cooling ton, spaced 6 to 12 feet apart. The soil characteristics and number of pipes per trench determine the trench length; more pipes (up to six) per trench save land space but require more piping.

Where significant land area or water volumes are not available, vertical closed-loop GSHPs may be the only option. In these systems the heat transfer pipes are placed vertically in the ground, at depths of between 75 and 300 feet. Some land area is still required, as the pipe wells need to be spaced at least 15 to 20 feet apart, and 200 to 600 feet of piping are needed per cooling ton.

For the purposes of this assessment, GSHPs were evaluated for various building sizes, vintages, and uses that are typically found on Army sites. Open-loop, horizontal closed-loop, and vertical closedloop configurations were analyzed for all building types. 


\section{Ground Source Heat Pump Analysis Approach}

Administration- and barracks-type buildings data with varying building characteristics were entered into the Facility Energy Decision System (FEDS) building energy model (see Appendix A) to determine cost effectiveness for GSHPs in a range of "typical” buildings. Site-specific TMY (typical meteorological year) weather data and soil/ground characteristics were used in the analysis, along with WSMR's current energy prices.

In this assessment, FEDS was used to find the most cost-effective GSHPs for each building type, and then optimized with more restrictions to determine if other GSHP configurations were also cost effective. This approach provides a reliable first cut to determine whether GSHPs might be economically feasible. It narrows the range of possibilities for potential projects, resulting in a list of building types that are worthwhile to investigate in more detail.

It is not a suitable basis for initiating a project; additional site-specific data collection is required to further narrow the options and develop specific project configurations. For instance, the model does not consider site limitations like land area or water source availability. The assumption is that there are sufficient thermal sources/sinks in place. Consequently, soil testing or other ways to evaluate soil characteristics are necessary before actual costs can be determined. Soil characteristics can change across the same site, so the assumptions the model makes based on one location may not be universal.

\section{Ground Source Heat Pump Resource Characterization}

The following building characteristics were used to represent a wide variety of typical administrative and barracks buildings found on an Army site.

- Size:

o $\quad 100,000 \mathrm{ft}^{2}$ (large)

o $\quad 50,000 \mathrm{ft}^{2}$ (medium)

o $\quad 10,000 \mathrm{ft}^{2}$ (small)

- Vintage (this affects many model assumptions, including the levels of insulation)
o 1945 (old)
o 1975 (mid-aged)
o 2000 (new)

- Heating type

- Gas boiler with air handling units (AHU)

o Gas boiler with fan coil units (FCU)

o Oil boiler with air handling units

o Oil boiler with fan coil units

o Central steam with air handling units

o Central steam with fan coil units

o Electric furnace

o Gas furnace

o Oil furnace

o Propane furnace

o Air-source heat pump (ASHP) 
- Cooling type (central plant systems were excluded because they aren't used at WSMR)

o Chiller with air handling units

o Chiller with fan coil units

o Package air conditioner (AC) / Direct Expansion (DX) unit

o Window / wall unit

o Air-source heat pump

The building characteristics analyzed represent most of the buildings found on an Army site. Smaller buildings may also present cost-effective options, but most smaller buildings are either family housing, which has been privatized, or buildings that do not result in much savings overall. Therefore, this assessment should adequately account for any buildings that are of primary retrofit interest.

GSHP assessments using FEDS have been completed at many sites in the past using the same analytic approach. The results developed here agree with previous findings. In general, conditions favoring replacement of existing heating and cooling systems with GSHPs include:

$\checkmark \quad$ Replacing old equipment. Equipment at the end of its useful life that will soon be replaced provides further economic incentive for GSHP installations, particularly if existing ductwork can be reused.

$\checkmark \quad$ More extreme climates. Cold winters, hot summers, or large daily temperature swings allow GSHPs to operate more efficiently than other electric cooling and heating systems. The cost of heating operation is comparable to non-electric heating systems.

$\checkmark$ High cost of non-electric fuels. If electricity is less than approximately 3.5 times as expensive per Btu than other fuels, GSHPs will generally be cost effective. If no other fuel option is available and electric costs are high, GSHPs will be less expensive to operate than air-source heat pumps.

GSHPs are often not cost effective in a building that:

$\checkmark$ Does not have both cooling and heating. A building needs to be both heated and cooled to take advantage of the GSHP efficiency in both modes.

$\checkmark$ Does not currently have ductwork. Installing an entirely new air distribution system in addition to the conditioning equipment generally adds too much cost for a GSHP retrofit, unless individual GSHP units are installed in each room in a barracks, for instance.

$\checkmark$ Is newer. Newer buildings (less than about 4 years old) generally have fairly efficient equipment (or at least the performance has not yet degraded significantly). As a result, premature replacement with a GSHP is generally uneconomic. In addition, the building envelope tends to be better, lengthening payback duration. 
$\checkmark \quad$ Is located in a mild climate. Buildings in fairly mild climates don't have the temperature extremes that make the ground loop important. A standard air-source heat pump would probably suffice.

$\checkmark$ Uses an air-source heat pump. An air-source heat pump has many of the benefits of a GSHP except in extreme temperature conditions. These extreme temperature conditions often aren't enough to justify replacement.

$\checkmark \quad$ Is connected to a central energy plant (unless the CEP will be abandoned). Although we often consider central energy systems as big energy wasters, on a building-by-building basis (which doesn't account for distribution losses) it's difficult to justify replacement. Centralized chiller plants can use larger, more efficient water-cooled units and can stage several chillers to run closer to full load (most efficient mode).

\section{Ground Source Heat Pumps: Economic and Other Analysis Parameters}

FEDS allows two primary financing options: appropriated funding (ECIP) and alternative financing (UESC/ESPC). The parameters for alternative financing can be adjusted to match the options available to the site. For this assessment, a project life of 25 years and a third-party interest rate of $5 \%$ were used.

FEDS uses the site electric rate schedule and energy costs to determine fuel costs and savings for GSHP retrofits. The entire rate schedule is used so that consumption and demand can be calculated on a time-of-use basis. At WSMR, electricity is charged according to the following flat rate:

$\checkmark \quad 4.219 \mathrm{\$} / \mathrm{kWh}$

$\checkmark \$ 19 / \mathrm{kW}$ demand

Natural gas costs $\$ 8.82 / \mathrm{MMBtu}$, based on historical and future trends according to NIST. Oil costs \$14.55/MMBtu, and propane costs \$16.24/MMBtu.

The average installed costs of GSHPs are shown in Table D-1. The difference in costs reflects economies of scale working in favor of larger installations. Where fewer or smaller units are being installed, the price increases comparatively with a similar technology.

Table D-1: Average Installed Costs for GSHPs

\begin{tabular}{|c|c|c|c|c|c|c|c|c|c|}
\hline & & \multicolumn{4}{|c|}{ ECIP Funding } & \multicolumn{4}{|c|}{ UESC/ESPC Financing } \\
\hline \multicolumn{2}{|c|}{ GSHP Type } & $\begin{array}{c}\text { Cost per } \\
\text { Unit } \\
\end{array}$ & \begin{tabular}{|c|} 
Avg Units \\
per Bldg
\end{tabular} & \begin{tabular}{|l|} 
Cost per \\
kBtu/hr
\end{tabular} & $\begin{array}{c}A v g \mathrm{kBtu} / \mathrm{hr} \\
\text { per Unit }\end{array}$ & \begin{tabular}{|c|} 
Cost per \\
Unit \\
\end{tabular} & \begin{tabular}{|l} 
Avg Units \\
per Bldg
\end{tabular} & $\begin{array}{l}\text { Cost per } \\
\mathrm{kBtu} / \mathrm{hr}\end{array}$ & $\begin{array}{c}\text { Avg } \mathrm{kBtu} / \mathrm{hr} \\
\text { per Unit }\end{array}$ \\
\hline Open Loop & High Efficiency & $\$ 8,573$ & 19.0 & $\$ 160$ & 53.73 & $\$ 7,255$ & 17.8 & $\$ 142$ & 51.25 \\
\hline Horizontal Closed Loop & High Efficiency & $\$ 12,630$ & 2.2 & $\$ 402$ & 31.4 & $\$ 7,779$ & 1.0 & $\$ 261$ & 29.78 \\
\hline Horizontal Closed Loop & Standard Efficiency, Small & $\$ 4,581$ & 1.0 & $\$ 254$ & 18.05 & $\$ 3,960$ & 1.0 & $\$ 219$ & 18.08 \\
\hline Vertical Closed Loop & High Efficiency & $\$ 19,090$ & 1.0 & $\$ 679$ & 28.1 & $\$ 14,615$ & 1.0 & $\$ 508$ & 28.76 \\
\hline Vertical Closed Loop & Standard Efficiency, Small & $\$ 11,442$ & 1.0 & $\$ 633$ & 18.09 & $\$ 9,863$ & 1.0 & $\$ 545$ & 18.09 \\
\hline
\end{tabular}




\section{Findings: Ground Source Heat Pumps}

The FEDS findings are shown below by building type. All of the analyzed technology combinations are shown in Table D-2 column and row headings, although only a few are applicable at WSMR. Empty cells indicate GSHPs are not cost effective for any building type analyzed. Detailed results in Tables D-3 through D-8 show which building sizes and vintages are using each of these replaceable equipment combinations, and which types of GSHP can economically replace the existing equipment.

Table D-2: Economic Evaluation of GSHP Opportunities at WSMR. Empty cells are not cost effective

\begin{tabular}{|c|c|c|c|c|c|}
\hline & $\begin{array}{l}\text { Chiller / Air } \\
\text { Handling Unit }\end{array}$ & $\begin{array}{c}\text { Chiller / Fan } \\
\text { Coil Unit }\end{array}$ & $\begin{array}{c}\text { Package DX } \\
\text { Units }\end{array}$ & $\begin{array}{l}\text { Window / } \\
\text { Wall Units }\end{array}$ & $\begin{array}{l}\text { Air Source } \\
\text { Heat Pump }\end{array}$ \\
\hline Gas Boiler / Air Handling Unit & $\begin{array}{c}\text { Admin } \\
\text { Barracks }\end{array}$ & & Admin & Admin & \\
\hline Gas Boiler / Fan Coil Unit & & & Admin & & \\
\hline Oil Boiler / Air Handling Unit & $\begin{array}{c}\text { Admin } \\
\text { Barracks }\end{array}$ & & $\begin{array}{c}\text { Admin } \\
\text { Barracks }\end{array}$ & $\begin{array}{c}\text { Admin } \\
\text { Barracks }\end{array}$ & \\
\hline Oil Boiler / Fan Coil Unit & & & $\begin{array}{c}\text { Admin } \\
\text { Barracks }\end{array}$ & & \\
\hline Central Steam / Air Handling Unit & $\begin{array}{c}\text { Admin } \\
\text { Barracks }\end{array}$ & & & & \\
\hline \multicolumn{6}{|l|}{ Central Steam / Fan Coil Unit } \\
\hline Electric Furnace & $\begin{array}{c}\text { Admin } \\
\text { Barracks }\end{array}$ & & $\begin{array}{c}\text { Admin } \\
\text { Barracks }\end{array}$ & Barracks & \\
\hline Gas Furnace & $\begin{array}{c}\text { Admin } \\
\text { Barracks }\end{array}$ & & & & \\
\hline Oil Furnace & $\begin{array}{c}\text { Admin } \\
\text { Barracks }\end{array}$ & & $\begin{array}{c}\text { Admin } \\
\text { Barracks }\end{array}$ & & \\
\hline Propane Furnace & $\begin{array}{c}\text { Admin } \\
\text { Barracks }\end{array}$ & & $\begin{array}{c}\text { Admin } \\
\text { Barracks }\end{array}$ & $\begin{array}{c}\text { Admin } \\
\text { Barracks }\end{array}$ & \\
\hline Air Source Heat Pump & & & & & \\
\hline
\end{tabular}

As expected, a number of technology combinations are not cost effective for any building. Airsource heat pumps and most fan coils cannot economically be replaced with GSHPs, whether the building is small, medium, or large, or old, mid-aged, or new. At WSMR, GSHPs tend to be more cost effective in administration buildings than in barracks.

The tables below show the cost-effective GSHP options for each building type analyzed under the ECIP funding scenario and the ESPC/UESC financing scenario, and their respective simple paybacks. There is a table for each GSHP type and funding scenario, and within these, each size and vintage is listed with the corresponding simple payback. If a technology cannot be economically replaced with GSHPs given a particular size and vintage, it is not listed in the tables.

The cost-effective ground source heat pump technologies are either high or standard efficiency, as described below. Simple paybacks for each are noted in brackets.

$\checkmark$ High efficiency: $\mathrm{COP}=4.2-4.5$

$\checkmark$ Standard efficiency: COP $=3.5-4.3$ 
Table D-3: Results for Open-Loop GSHPs at WSMR - ECIP Funding Scenario

\begin{tabular}{|c|c|c|c|c|}
\hline & & Chiller / Air Handling Unit & Package DX Units & Window / Wall Units \\
\hline \multirow{3}{*}{ 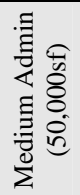 } & \begin{tabular}{|c|} 
Oil / Air Handling \\
Unit
\end{tabular} & $\begin{array}{l}\text { Old - high efficiency [10.0 yrs] } \\
\text { Mid-Aged - high efficiency [11.3 yrs] }\end{array}$ & & \\
\hline & Oil Furnace & Old - high efficiency [10.6 yrs] & & \\
\hline & Propane Furnace & Old - high efficiency [10.2 yrs] & & \\
\hline \multirow{7}{*}{ 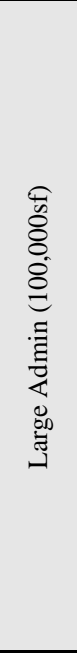 } & $\begin{array}{c}\text { Gas / Air } \\
\text { Handling Unit }\end{array}$ & & Old - high efficiency [9.6 yrs] & \\
\hline & $\begin{array}{l}\text { Gas / Fan Coil } \\
\text { Unit }\end{array}$ & & Old - high efficiency [9.6 yrs] & \\
\hline & \begin{tabular}{|c} 
Oil / Air Handling \\
Unit
\end{tabular} & & $\begin{array}{l}\text { Old - high efficiency [8.7 yrs] } \\
\text { Mid-Aged - high efficiency [8.7 yrs] }\end{array}$ & \\
\hline & $\begin{array}{l}\text { Oil / Fan Coil } \\
\text { Unit }\end{array}$ & & $\begin{array}{l}\text { Old - high efficiency [8.2 yrs] } \\
\text { Mid-Aged - high efficiency [8.3 yrs] } \\
\text { New - high efficiency [9.0 yrs] }\end{array}$ & \\
\hline & Electric Furnace & & $\begin{array}{l}\text { Old - high efficiency [9.0 yrs] } \\
\text { Mid-Aged - high efficiency [9.2 yrs] } \\
\text { New - high efficiency [9.6 yrs] }\end{array}$ & \\
\hline & Oil Furnace & & $\begin{array}{l}\text { Old - high efficiency [8.6 yrs] } \\
\text { New - high efficiency [9.5 yrs] }\end{array}$ & \\
\hline & Propane Furnace & & $\begin{array}{l}\text { Old - high efficiency [8.2 yrs] } \\
\text { Mid-Aged - high efficiency [9.2 yrs] } \\
\text { New - high efficiency [9.2 yrs] }\end{array}$ & Old - high efficiency [9.3 yrs] \\
\hline \multirow{3}{*}{ 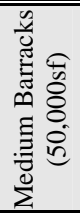 } & \begin{tabular}{|c|} 
Oil / Air Handling \\
Unit \\
\end{tabular} & Old - high efficiency [10.3 yrs] & & \\
\hline & Electric Furnace & Old - high efficiency [10.2 yrs] & & \\
\hline & Propane Furnace & |Old - high efficiency [10.5 yrs] & & \\
\hline \multirow{6}{*}{ 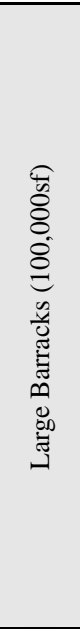 } & $\begin{array}{c}\text { Gas / Air } \\
\text { Handling Unit }\end{array}$ & Mid-Aged - high efficiency [9.3 yrs] & & \\
\hline & \begin{tabular}{|} 
Oil / Air Handling \\
Unit
\end{tabular} & \begin{tabular}{|l} 
Old - high efficiency [6.5 yrs] \\
Mid-Aged - high efficiency [6.4 yrs] \\
New - high efficiency [ 7.7 yrs]
\end{tabular} & $\begin{array}{l}\text { Old - high efficiency [7.5 yrs] } \\
\text { Mid-Aged - high efficiency [7.3 yrs] } \\
\text { New - high efficiency [9.0 yrs] }\end{array}$ & $\begin{array}{l}\text { Old - high efficiency [8.5 yrs] } \\
\text { Mid-Aged - high efficiency [7.9 yrs] }\end{array}$ \\
\hline & $\begin{array}{l}\text { Oil / Fan Coil } \\
\text { Unit }\end{array}$ & & $\begin{array}{l}\text { Old - high efficiency [7.1 yrs] } \\
\text { Mid-Aged - high efficiency [7.0 yrs] } \\
\text { New - high efficiency [8.6 yrs] }\end{array}$ & \\
\hline & Electric Furnace & \begin{tabular}{|l} 
Old - high efficiency [5.6 yrs] \\
Mid-Aged - high efficiency [5.9 yrs] \\
New - high efficiency [6.1 yrs]
\end{tabular} & $\begin{array}{l}\text { Old - high efficiency [6.2 yrs] } \\
\text { Mid-Aged - high efficiency [6.6 yrs] } \\
\text { New - high efficiency [6.8 yrs] }\end{array}$ & $\begin{array}{l}\text { Old - high efficiency [6.6 yrs] } \\
\text { Mid-Aged - high efficiency [7.0 yrs] } \\
\text { New - high efficiency [7.3 yrs] }\end{array}$ \\
\hline & Oil Furnace & $\begin{array}{l}\text { Old - high efficiency [7.4 yrs] } \\
\text { Mid-Aged - high efficiency [7.6 yrs] } \\
\text { New - high efficiency [7.9 yrs] }\end{array}$ & $\begin{array}{l}\text { Old - high efficiency [8.5 yrs] } \\
\text { Mid-Aged - high efficiency [9.2 yrs] } \\
\text { New - high efficiency [9.2 yrs] }\end{array}$ & \\
\hline & Propane Furnace & \begin{tabular}{|l} 
Old - high efficiency [6.8 yrs] \\
Mid-Aged - high efficiency [ $7.1 \mathrm{yrs}]$ \\
New - high efficiency [ 7.4 yrs]
\end{tabular} & $\begin{array}{l}\text { Old - high efficiency [7.8 yrs] } \\
\text { Mid-Aged - high efficiency [8.2 yrs] } \\
\text { New - high efficiency [8.5 yrs] }\end{array}$ & $\begin{array}{l}\text { Old - high efficiency [8.4 yrs] } \\
\text { Mid-Aged - high efficiency [9.3 yrs] } \\
\text { New - high efficiency [9.3 yrs] }\end{array}$ \\
\hline
\end{tabular}

These more detailed results show that large buildings and old buildings are much more likely to be cost effective for open-loop GSHP retrofits. Groundwater is relatively deep at WSMR, so drilling costs are high and result in fewer viable projects. 
Table D-4: Results for Horizontal Closed-Loop GSHPs at WSMR - ECIP Funding Scenario

\begin{tabular}{|c|c|c|c|c|}
\hline & & Chiller / Air Handling Unit & Package DX Units & Window / Wall Units \\
\hline \multirow{9}{*}{ 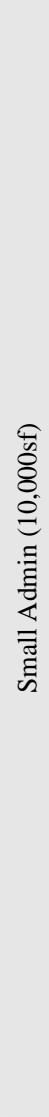 } & $\begin{array}{l}\text { Gas / Air } \\
\text { Handling } \\
\text { Unit }\end{array}$ & $\begin{array}{l}\text { Old - high efficiency [5.0 yrs] } \\
\text { Mid-Aged - standard efficiency [3.0 yrs] } \\
\text { New - standard efficiency [3.2 yrs] }\end{array}$ & $\begin{array}{l}\text { Mid-Aged - standard efficiency [13.2 } \\
\text { yrs] }\end{array}$ & $\begin{array}{l}\text { Mid-Aged - standard efficiency [11.5 } \\
\text { yrs] } \\
\text { New - standard efficiency [12.8 yrs] }\end{array}$ \\
\hline & $\begin{array}{c}\text { Gas / } \\
\text { Fan Coil } \\
\text { Unit } \\
\end{array}$ & & $\begin{array}{l}\text { Mid-Aged - standard efficiency [12.7 } \\
\text { yrs] }\end{array}$ & \\
\hline & $\begin{array}{l}\text { Oil / Air } \\
\text { Handling } \\
\text { Unit }\end{array}$ & $\begin{array}{l}\text { Old - high efficiency [4.6 yrs] } \\
\text { Mid-Aged - standard efficiency [2.9 yrs] } \\
\text { New - standard efficiency [3.1 yrs] }\end{array}$ & $\begin{array}{l}\text { Mid-Aged - standard efficiency [11.1 } \\
\text { yrs] } \\
\text { New - standard efficiency [12.9 yrs] }\end{array}$ & $\begin{array}{l}\text { Old - high efficiency [11.7 yrs] } \\
\text { Mid-Aged - standard efficiency [9.9 } \\
\text { yrs] } \\
\text { New - standard efficiency [11.3 yrs] }\end{array}$ \\
\hline & $\begin{array}{l}\text { Oil / Fan } \\
\text { Coil } \\
\text { Unit }\end{array}$ & & $\begin{array}{l}\text { Old - high efficiency [12.8 yrs] } \\
\text { Mid-Aged - standard efficiency [10.7 } \\
\text { yrs] } \\
\text { New - standard efficiency [12.5 yrs] }\end{array}$ & \\
\hline & $\begin{array}{l}\text { Steam / } \\
\text { Air } \\
\text { Handling } \\
\text { Unit } \\
\end{array}$ & $\begin{array}{l}\text { Old - high efficiency [5.5 yrs] } \\
\text { Mid-Aged - standard efficiency [3.3 yrs] } \\
\text { New - standard efficiency [3.5 yrs] }\end{array}$ & & \\
\hline & $\begin{array}{l}\text { Electric } \\
\text { Furnace }\end{array}$ & $\begin{array}{l}\text { Old - high efficiency [5.4 yrs] } \\
\text { Mid-Aged - standard efficiency [3.3 yrs] } \\
\text { New - standard efficiency [3.4 yrs] }\end{array}$ & & \\
\hline & $\begin{array}{c}\text { Gas } \\
\text { Furnace }\end{array}$ & $\begin{array}{l}\text { Old - high efficiency [5.4 yrs] } \\
\text { Mid-Aged - standard efficiency [3.3 yrs] } \\
\text { New - standard efficiency [3.4 yrs] }\end{array}$ & & \\
\hline & $\begin{array}{c}\text { Oil } \\
\text { Furnace }\end{array}$ & $\begin{array}{l}\text { Old - high efficiency [5.0 yrs] } \\
\text { Mid-Aged - standard efficiency [3.1 yrs] } \\
\text { New - standard efficiency [3.3 yrs] }\end{array}$ & & \\
\hline & $\begin{array}{l}\text { Propane } \\
\text { Furnace }\end{array}$ & $\begin{array}{l}\text { Old - high efficiency [4.9 yrs] } \\
\text { Mid-Aged - standard efficiency [3.1 yrs] } \\
\text { New - standard efficiency [3.3 yrs] }\end{array}$ & & \\
\hline
\end{tabular}


Table D-4: Continued

\begin{tabular}{|c|c|c|c|c|}
\hline & & Chiller / Air Handling Unit & Package DX Units & Window / Wall Units \\
\hline \multirow{7}{*}{ 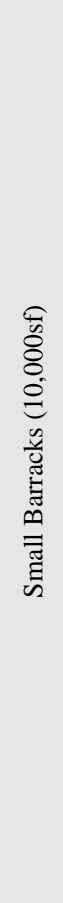 } & $\begin{array}{l}\text { Gas / Air } \\
\text { Handling } \\
\text { Unit }\end{array}$ & $\begin{array}{l}\text { Old - high efficiency [6.9 yrs] } \\
\text { Mid-Aged - high efficiency [5.1 yrs] } \\
\text { New - high efficiency [5.3 yrs] }\end{array}$ & & \\
\hline & $\begin{array}{l}\text { Oil / Air } \\
\text { Handling } \\
\text { Unit }\end{array}$ & $\begin{array}{l}\text { Old - high efficiency [6.4 yrs] } \\
\text { Mid-Aged - high efficiency [4.9 yrs] } \\
\text { New - high efficiency [5.2 yrs] }\end{array}$ & & \\
\hline & $\begin{array}{l}\text { Steam / } \\
\text { Air } \\
\text { Handling } \\
\text { Unit }\end{array}$ & $\begin{array}{l}\text { Old - high efficiency [7.7 yrs] } \\
\text { Mid-Aged - high efficiency [5.6 yrs] } \\
\text { New - high efficiency [5.8 yrs] }\end{array}$ & & \\
\hline & $\begin{array}{l}\text { Electric } \\
\text { Furnace }\end{array}$ & $\begin{array}{l}\text { Old - high efficiency [7.0 yrs] } \\
\text { Mid-Aged - high efficiency [5.4 yrs] } \\
\text { New - high efficiency [5.6 yrs] }\end{array}$ & & \\
\hline & $\begin{array}{c}\text { Gas } \\
\text { Furnace }\end{array}$ & $\begin{array}{l}\text { Old - high efficiency [7.6 yrs] } \\
\text { Mid-Aged - high efficiency [5.4 yrs] } \\
\text { New - high efficiency [5.7 yrs] }\end{array}$ & & \\
\hline & $\begin{array}{c}\text { Oil } \\
\text { Furnace }\end{array}$ & $\begin{array}{l}\text { Old - high efficiency [6.9 yrs] } \\
\text { Mid-Aged - high efficiency [5.3 yrs] } \\
\text { New - high efficiency [5.6 yrs] }\end{array}$ & & \\
\hline & $\begin{array}{l}\text { Propane } \\
\text { Furnace }\end{array}$ & $\begin{array}{l}\text { Old - high efficiency [6.8 yrs] } \\
\text { Mid-Aged - high efficiency [5.3 yrs] } \\
\text { New - high efficiency [5.6 yrs] }\end{array}$ & & \\
\hline 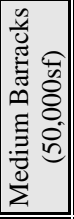 & $\begin{array}{l}\text { Electric } \\
\text { Furnace }\end{array}$ & Old - high efficiency [12.7 yrs] & & \\
\hline 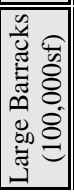 & $\begin{array}{l}\text { Electric } \\
\text { Furnace }\end{array}$ & $\begin{array}{l}\text { Old - high efficiency [12.1 yrs] } \\
\text { Mid-Aged - high efficiency [12.7 yrs] }\end{array}$ & & \\
\hline
\end{tabular}

The more detailed horizontal results show that replacing chillers with air handling units is the most cost-effective option, especially in small buildings and regardless of the building vintage. 
Table D-5: Results for Vertical Closed-Loop GSHPs at WSMR - ECIP Funding Scenario

\begin{tabular}{|c|c|c|}
\hline & & Chiller / Air Handling Unit \\
\hline \multirow{7}{*}{ 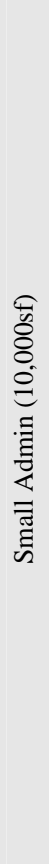 } & Gas / Air Handling Unit & $\begin{array}{l}\text { Old - high efficiency [9.7 yrs] } \\
\text { Mid-Aged - standard efficiency [7.4 yrs] } \\
\text { New - standard efficiency [7.9 yrs] }\end{array}$ \\
\hline & Oil / Air Handling Unit & $\begin{array}{l}\text { Old - high efficiency [9.0 yrs] } \\
\text { Mid-Aged - standard efficiency [7.1 yrs] } \\
\text { New - standard efficiency [7.7 yrs] }\end{array}$ \\
\hline & Steam / Air Handling Unit & $\begin{array}{l}\text { Old - high efficiency [10.7 yrs] } \\
\text { Mid-Aged - standard efficiency [8.2 yrs] } \\
\text { New - standard efficiency [8.7 yrs] }\end{array}$ \\
\hline & Electric Furnace & $\begin{array}{l}\text { Old - high efficiency [10.6 yrs] } \\
\text { Mid-Aged - standard efficiency [8.1 yrs] } \\
\text { New - standard efficiency [8.6 yrs] }\end{array}$ \\
\hline & Gas Furnace & $\begin{array}{l}\text { Old - high efficiency [10.5 yrs] } \\
\text { Mid-Aged - standard efficiency [8.0 yrs] } \\
\text { New - standard efficiency [8.5 yrs] }\end{array}$ \\
\hline & Oil Furnace & $\begin{array}{l}\text { Old - high efficiency [9.7 yrs] } \\
\text { Mid-Aged - standard efficiency [7.7 yrs] } \\
\text { New - standard efficiency [8.2 yrs] }\end{array}$ \\
\hline & Propane Furnace & $\begin{array}{l}\text { Old - high efficiency [9.6 yrs] } \\
\text { Mid-Aged - standard efficiency [7.6 yrs] } \\
\text { New - standard efficiency [8.2 yrs] }\end{array}$ \\
\hline \multirow{5}{*}{ 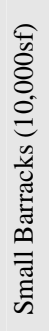 } & Gas / Air Handling Unit & Mid-Aged - high efficiency [13.2 yrs] \\
\hline & Oil / Air Handling Unit & $\begin{array}{l}\text { Old - high efficiency [13.3 yrs] } \\
\text { Mid-Aged - high efficiency [12.9 yrs] } \\
\text { New - high efficiency [14.0 yrs] }\end{array}$ \\
\hline & Electric Furnace & Mid-Aged - high efficiency [14.0 yrs] \\
\hline & Oil Furnace & Mid-Aged - high efficiency [13.9 yrs] \\
\hline & Propane Furnace & Mid-Aged - high efficiency [13.9 yrs] \\
\hline
\end{tabular}

Vertical loops are much more expensive than horizontal loops because of the high cost of drilling as compared to the cost of trenching. Therefore, there are many fewer cost-effective options here, and the paybacks are longer. Small buildings are the only cost-effective option, and building vintage is still only a minor factor in cost effectiveness.

Alternative financing, like UESC or ESPC, increases the costs, resulting in fewer GSHPs being cost effective. 


\section{Table D-6: Results for Open-Loop GSHPs at WSMR - Alternative Financing (UESC/ESPC) Scenario}

\begin{tabular}{|c|c|c|c|c|}
\hline & & Chiller / Air Handling Unit & Package DX Units & Window / Wall Units \\
\hline \multirow{5}{*}{ 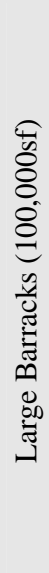 } & $\begin{array}{l}\text { Oil / Air } \\
\text { Handling } \\
\text { Unit }\end{array}$ & $\begin{array}{l}\text { Old - high efficiency [5.6 yrs] } \\
\text { Mid-Aged - high efficiency [5.5 yrs] } \\
\text { New - high efficiency [6.6 yrs] }\end{array}$ & $\begin{array}{l}\text { Old - high efficiency [6.4 yrs] } \\
\text { Mid-Aged - high efficiency [6.3 yrs] }\end{array}$ & \\
\hline & $\begin{array}{l}\text { Oil / Fan } \\
\text { Coil Unit }\end{array}$ & & $\begin{array}{l}\text { Old - high efficiency [6.2 yrs] } \\
\text { Mid-Aged - high efficiency [6.1 yrs] }\end{array}$ & \\
\hline & $\begin{array}{l}\text { Electric } \\
\text { Furnace }\end{array}$ & $\begin{array}{l}\text { Old - high efficiency [4.8 yrs] } \\
\text { Mid-Aged - high efficiency [5.1 yrs] } \\
\text { New - high efficiency [5.3 yrs] }\end{array}$ & $\begin{array}{l}\text { Old - high efficiency [5.3 yrs] } \\
\text { Mid-Aged - high efficiency [5.7 yrs] } \\
\text { New - high efficiency [5.9 yrs] }\end{array}$ & $\begin{array}{l}\text { Old - high efficiency [5.7 yrs] } \\
\text { Mid-Aged - high efficiency [6.1 yrs] } \\
\text { New - high efficiency [6.3 yrs] }\end{array}$ \\
\hline & $\begin{array}{c}\text { Oil } \\
\text { Furnace }\end{array}$ & $\begin{array}{l}\text { Old - high efficiency [6.4 yrs] } \\
\text { Mid-Aged - high efficiency [6.6 yrs] } \\
\text { New - high efficiency [6.8 yrs] }\end{array}$ & & \\
\hline & $\begin{array}{l}\text { Propane } \\
\text { Furnace }\end{array}$ & \begin{tabular}{||l} 
Old - high efficiency [5.9 yrs] \\
Mid-Aged - high efficiency [6.1 yrs] \\
New - high efficiency [6.4 yrs]
\end{tabular} & $\begin{array}{l}\text { Old - high efficiency [6.7 yrs] } \\
\text { Mid-Aged - high efficiency [7.1 yrs] }\end{array}$ & \\
\hline
\end{tabular}

Only large barracks can cost effectively have HVAC systems replaced with open-loop GSHPs if the project is financed.

Table D-7: Results for Horizontal Closed-Loop GSHPs at WSMR - Alternative Financing (UESC/ESPC) Scenario

\begin{tabular}{|c|c|c|c|}
\hline & Chiller / Air Handling Unit & Window / Wall Units \\
\hline \multirow{7}{*}{ 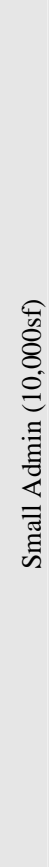 } & $\begin{array}{l}\text { Gas / Air } \\
\text { Handling } \\
\text { Unit }\end{array}$ & $\begin{array}{l}\text { Old - high efficiency [4.3 yrs] } \\
\text { Mid-Aged - standard efficiency [2.6 yrs] } \\
\text { New - standard efficiency [2.7 yrs] }\end{array}$ & \\
\hline & $\begin{array}{l}\text { Oil / Air } \\
\text { Handling } \\
\text { Unit }\end{array}$ & $\begin{array}{l}\text { Old - high efficiency [4.0 yrs] } \\
\text { Mid-Aged - standard efficiency [2.5 yrs] } \\
\text { New - standard efficiency [2.6 yrs] }\end{array}$ & Mid-Aged - standard efficiency [8.5 yrs] \\
\hline & $\begin{array}{l}\text { Steam / Air } \\
\text { Handling } \\
\text { Unit }\end{array}$ & $\begin{array}{l}\text { Old - high efficiency [ } 4.7 \mathrm{yrs}] \\
\text { Mid-Aged - standard efficiency [2.9 yrs] } \\
\text { New - standard efficiency [3.0 yrs] }\end{array}$ & \\
\hline & $\begin{array}{l}\text { Electric } \\
\text { Furnace }\end{array}$ & $\begin{array}{l}\text { Old - high efficiency [ } 4.7 \mathrm{yrs} \text { ] } \\
\text { Mid-Aged - standard efficiency [2.8 yrs] } \\
\text { New - standard efficiency [3.0 yrs] }\end{array}$ & \\
\hline & $\begin{array}{c}\text { Gas } \\
\text { Furnace }\end{array}$ & $\begin{array}{l}\text { Old - high efficiency [4.6 yrs] } \\
\text { Mid-Aged - standard efficiency [2.8 yrs] } \\
\text { New - standard efficiency [2.9 yrs] }\end{array}$ & \\
\hline & $\begin{array}{c}\text { Oil } \\
\text { Furnace }\end{array}$ & $\begin{array}{l}\text { Old - high efficiency [4.3 yrs] } \\
\text { Mid-Aged - standard efficiency [2.7 yrs] } \\
\text { New - standard efficiency [2.8 yrs] }\end{array}$ & \\
\hline & $\begin{array}{l}\text { Propane } \\
\text { Furnace }\end{array}$ & $\begin{array}{l}\text { Old - high efficiency [4.2 yrs] } \\
\text { Mid-Aged - standard efficiency [2.7 yrs] } \\
\text { New - standard efficiency [2.8 yrs] }\end{array}$ & \\
\hline
\end{tabular}


Table D-7 (Continued)

\begin{tabular}{|c|c|c|c|}
\hline & & Chiller / Air Handling Unit & Window / Wall Units \\
\hline \multirow{7}{*}{ 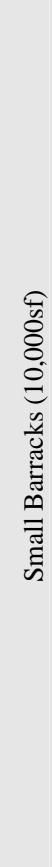 } & $\begin{array}{l}\text { Gas / Air } \\
\text { Handling } \\
\text { Unit }\end{array}$ & $\begin{array}{l}\text { Old - high efficiency [6.0 yrs] } \\
\text { Mid-Aged - high efficiency [4.4 yrs] } \\
\text { New - high efficiency [4.6 yrs] }\end{array}$ & \\
\hline & $\begin{array}{l}\text { Oil / Air } \\
\text { Handling } \\
\text { Unit }\end{array}$ & $\begin{array}{l}\text { Old - high efficiency [5.5 yrs] } \\
\text { Mid-Aged - high efficiency [4.3 yrs] } \\
\text { New - high efficiency [4.5 yrs] }\end{array}$ & \\
\hline & $\begin{array}{c}\text { Steam / Air } \\
\text { Handling } \\
\text { Unit }\end{array}$ & $\begin{array}{l}\text { Old - high efficiency [6.6 yrs] } \\
\text { Mid-Aged - high efficiency [4.8 yrs] } \\
\text { New - high efficiency [5.0 yrs] }\end{array}$ & \\
\hline & $\begin{array}{l}\text { Electric } \\
\text { Furnace }\end{array}$ & $\begin{array}{l}\text { Old - high efficiency [6.1 yrs] } \\
\text { Mid-Aged - high efficiency [4.6 yrs] } \\
\text { New - high efficiency [4.9 yrs] }\end{array}$ & \\
\hline & $\begin{array}{c}\text { Gas } \\
\text { Furnace }\end{array}$ & $\begin{array}{l}\text { Old - high efficiency [6.5 yrs] } \\
\text { Mid-Aged - high efficiency [4.7 yrs] } \\
\text { New - high efficiency [4.9 yrs] }\end{array}$ & \\
\hline & $\begin{array}{c}\text { Oil } \\
\text { Furnace }\end{array}$ & $\begin{array}{l}\text { Old - high efficiency [6.0 yrs] } \\
\text { Mid-Aged - high efficiency [4.6 yrs] } \\
\text { New - high efficiency [4.8 yrs] }\end{array}$ & \\
\hline & $\begin{array}{l}\text { Propane } \\
\text { Furnace }\end{array}$ & $\begin{array}{l}\text { Old - high efficiency [5.8 yrs] } \\
\text { Mid-Aged - high efficiency [4.6 yrs] } \\
\text { New - high efficiency [4.8 yrs] }\end{array}$ & \\
\hline
\end{tabular}

Table D-8: Results for Vertical Closed-Loop GSHPs at WSMR - Alternative Financing (UESC/ESPC) Scenario

\begin{tabular}{|c|c|c|}
\hline & & Chiller / Air Handling Unit \\
\hline \multirow{7}{*}{ 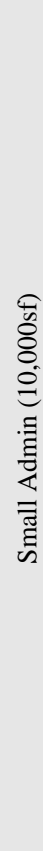 } & Gas / Air Handling Unit & $\begin{array}{l}\text { Old - high efficiency [8.4 yrs] } \\
\text { Mid-Aged - standard efficiency [6.3 yrs] } \\
\text { New - standard efficiency [6.8 yrs] }\end{array}$ \\
\hline & Oil / Air Handling Unit & $\begin{array}{l}\text { Old - high efficiency [7.8 yrs] } \\
\text { Mid-Aged - standard efficiency [6.1 yrs] } \\
\text { New - standard efficiency [6.6 yrs] }\end{array}$ \\
\hline & Steam / Air Handling Unit & $\begin{array}{l}\text { Old - high efficiency [9.2 yrs] } \\
\text { Mid-Aged - standard efficiency [7.1 yrs] } \\
\text { New - standard efficiency [7.5 yrs] }\end{array}$ \\
\hline & Electric Furnace & $\begin{array}{l}\text { Old - high efficiency [9.1 yrs] } \\
\text { Mid-Aged - standard efficiency [7.0 yrs] } \\
\text { New - standard efficiency [7.4 yrs] }\end{array}$ \\
\hline & Gas Furnace & $\begin{array}{l}\text { Old - high efficiency [9.1 yrs] } \\
\text { Mid-Aged - standard efficiency [6.9 yrs] } \\
\text { New - standard efficiency [7.3 yrs] }\end{array}$ \\
\hline & Oil Furnace & $\begin{array}{l}\text { Old - high efficiency [8.4 yrs] } \\
\text { Mid-Aged - standard efficiency [6.6 yrs] } \\
\text { New - standard efficiency [7.1 yrs] }\end{array}$ \\
\hline & Propane Furnace & $\begin{array}{l}\text { Old - high efficiency [8.2 yrs] } \\
\text { Mid-Aged - standard efficiency [6.6 yrs] } \\
\text { New - standard efficiency [7.1 yrs] }\end{array}$ \\
\hline
\end{tabular}


Only small buildings with chillers and air handling units are cost effective in this scenario, regardless of vintage or building type. However, older buildings tend to be slightly less cost effective than other vintages, while admin facilities tend to be slightly more cost effective than barracks.

With alternative financing, only small admin facilities with chillers and air handling units are costeffective options for vertical closed-loop GSHPs. Older facilities tend to be slightly less cost effective, but all vintages are viable options.

The total potential energy savings for WSMR is not possible to determine at this point, because these results are not tied to specific buildings on site. This assessment is intended to show where potential may exist, to proceed with a promising detailed investigation.

\section{Ground Source Heat Pumps: Next steps}

WSMR needs to determine whether water for open-loop systems is available, and if so, if it is environmentally acceptable to use them for GSHP development. WSMR's current building stock then needs to be compared to the building types listed above, and matched to the cost-effective technology combinations. Where there are similarities, detailed building and surrounding land area information should be collected to pursue project viability. Buildings that are not administrative or barracks can be considered administration for the purposes of this preliminary assessment because most other buildings on site will have occupancies similar to that of administration buildings.

With more detailed land area information, some buildings will be excluded from further consideration, while other buildings may be excluded only from certain GSHP configurations. With more detailed building information on these remaining buildings, FEDS could be used to more accurately calculate costs and energy savings, and develop a list of buildings where projects should be developed. Experienced designers in the area can then be contacted to develop detailed project designs.

\section{Ground Source Heat Pump References}

Federal Technology Alert. "Ground Source Heat Pumps Applied to Federal Facilities - Second Edition.” Federal Energy Management Program. DOE/EE-0245. March 2001. http://www1.eere.energy.gov/femp/pdfs/FTA_gshp.pdf 
APPENDIX E

\section{Analysis of Solar Opportunities}


Renewable Energy Opportunities at White Sands

Missile Range, New Mexico

Pacific Northwest National Laboratory, Sept 2008 


\section{Appendix E: Analysis of Solar Opportunities}

\section{Solar Technology}

There is a wide range of solar technologies and applications available. Solar technologies can be classified by the specific method for converting solar energy into useful energy for direct use as a substitute for a conventional energy source. Solar energy is unique in that the sun's energy can be captured to provide electrical energy, heating energy (solar thermal), or a combination of both. Solar electric collectors are either photovoltaic (PV) arrays or concentrating solar arrays. There are three major PV array subcategories, as follows:

* Flat Panel. Arrays of PV modules mounted on racks either at ground level or on rooftops at a

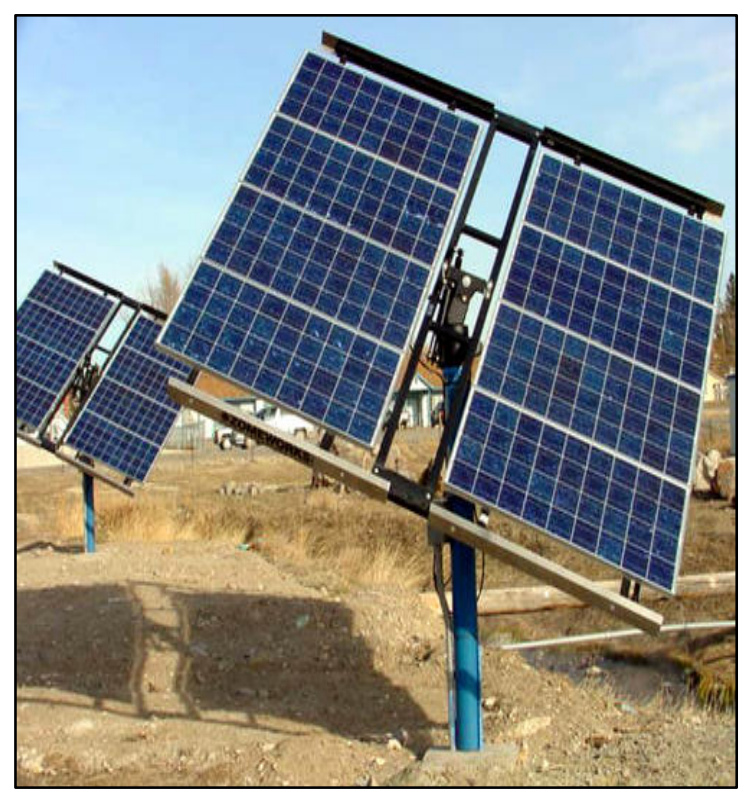

Figure E-1: Axis tracking PV array

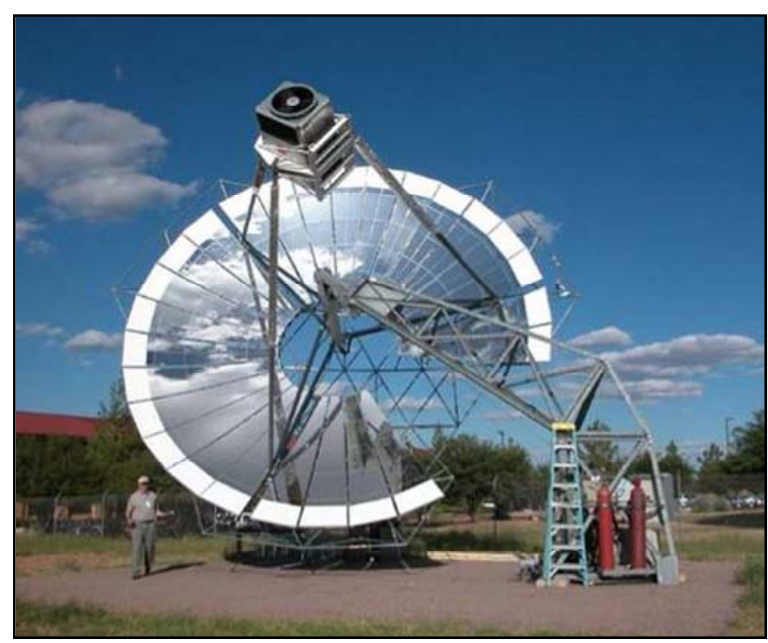

Figure E-3: Fort Huachuca Stirling solar engine fixed angle - generally this angle is equal to the location latitude.

* Axis Tracking. PV arrays mounted on an assembly that moves throughout the day keeping the array pointed directly at optimum angle to capture sunlight (Figure E-1).

* Integrated PV Products. PV is available integrated with building materials which provides a cleaner look than stand-alone panels. PV comes as replacements for standard three-tab shingles, metal standing-seam roofing, and membrane roofing for flat roofs (Figure E-2).

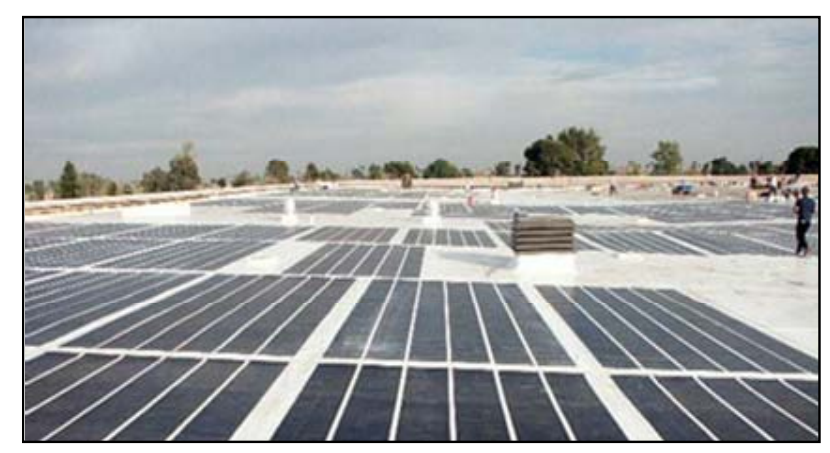

Figure E-2: Integrated PV on Base

Concentrating solar power (CSP) systems use mirrors to concentrate the sun's energy on a central receiver, delivering higher temperatures for power production. There are three primary configurations for CSP as follows:

* Stirling Engine. A stirling engine is a mechanical device that when heated by the sun uses expanding and contracting gases to drive a piston that produces energy (Figure E-3). 
* Central tower. Very large arrays of mirrors concentrate the sun's energy on a central receiver tower to produce steam to drive a generator.

* Solar Trough. When used for power generation these very large arrays concentrate the sun’s energy on a pipe containing a liquid which in turn is used to generate steam to drive a generator.

Rather than electricity as the end product, solar energy can also be used to heat air directly, heat water that is used for space heating, or heat water that is directly used for service hot water (SHW) or swimming pools. Solar thermal collectors can take many forms, including:

* Transpired solar collector. These collectors sometimes called solar walls - preheat incoming air to a building by drawing intake air through perforated panels installed on the southern exposure of buildings (Figure E-4).

* Solar Trough. Similar in design to troughs used to generate power, but smaller in scope, solar troughs can be used to heat/pre-heat water for hydronic systems.

* Flat-plate collector. Glazed flat-plate collectors are insulated, weatherproofed boxes that contain a dark absorber plate under one or more glass or plastic (polymer) covers.

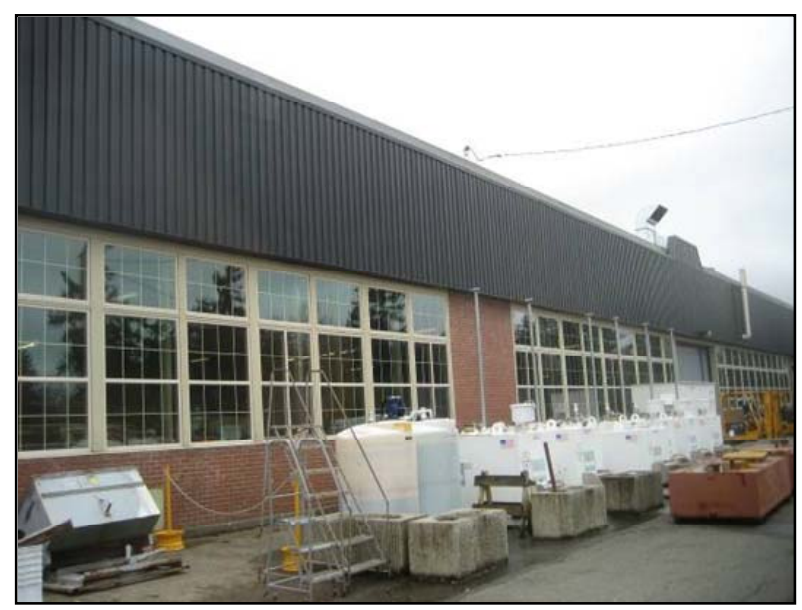

Figure E-4: Solar wall installed at Fort Lewis

* Evacuated-tube solar collector. They feature parallel rows of transparent glass tubes. Each tube contains a glass outer tube and metal absorber tube attached to a fin. The fin's coating absorbs solar energy but inhibits radiative heat loss.

Finally, daylighting fixtures are becoming important. Modern versions of traditional skylights have better insulating properties and light dispersion. Some are integrated into a standard 2x4 foot fluorescent fixture. Light shelves, atriums, and solar tubes are other examples of daylighting fixtures (Figure E-5).

Solar technologies can be further categorized by their scale. Large-scale solar projects can be massive in scope with hundreds of collectors and solar energy output expressed in hundreds of kilowatts of energy. Smaller-scale projects, often called building-integrated, are also possible and may be more desirable because of space limitations, for aesthetics, or other reasons. Certain solar technologies, like photovoltaic, can

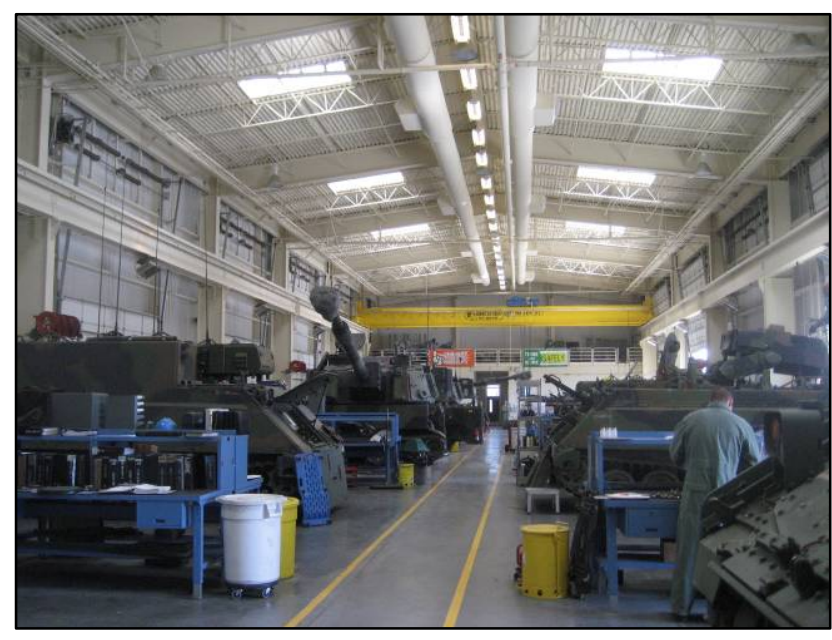

Figure E-5: Daylighting fixtures at the Yakima Training Center 
be either large-scale or small-scale, while technologies like solar walls are only found at the building level.

\section{Solar Analysis Approach}

The analytic approach for the solar energy assessment consists of the following steps:

$\checkmark \quad$ Identify solar potential-Determine seasonal and annual solar radiation from existing sources.

$\checkmark \quad$ Determine utility perspective-Obtain electric rate tariff information, evaluate state and local regulations, and identify grants, incentives and other support.

$\checkmark \quad$ Identify potential development areas-Identify installation-specific sites and potential users of generated energy (on-site and/or off-site use). Study existing electrical transmission system and identify potential users of waste thermal energy (building, process, central energy plants).

$\checkmark \quad$ Determine applicable solar technology_Evaluate electric technologies including both large- and small-scale.

$\checkmark \quad$ Develop project economics-Determine project capital investment requirements, project operations and maintenance costs, and estimate economic value of expected electric production based on selected solar technology and market prices.

Resource potential was estimated using the solar potential estimates in the National Aeronautics and Space Administration (NASA) Surface meteorology and Solar Energy (SSE). The SSE data set is a continuous and consistent 10-year global climatology of insolation and meteorology data on a $1^{\circ}$ by $1^{\circ}$ grid system. Although the SSE data within a particular grid cell are not necessarily representative of a particular microclimate, or point, within the cell, the data are considered to be the average over the entire area of the cell. That estimate may be accurate enough for preliminary feasibility studies of new renewable energy projects. In addition, SSE provides year-to-year variability in terms of 10year maximums and minimums for a number of parameters.

For each site, the average solar insolation data is shown for three different types of surfaces: flat roof surface, a flat panel with a tilt equal to the latitude, and a flat wall mounted panel. Average monthly insolation is given in $\mathrm{kWh} / \mathrm{m}^{2}$-day for the following conditions:

o Tilt 0 - Collectors install flat (i.e., on a flat roof surface)

o Tilt (lat-15) - A tilt of latitude minus 15 degrees would favor energy production in the summer when the sun is higher

o Tilt lat - Tilting a PV array at an angle equal to the latitude is a generally accepted way to optimize electricity production

o Tilt (lat+15) - A tilt of latitude plus 15 degrees would favor energy production in the winter when the sun is lower

o Tilt 90 - Collector installed against a vertical surface (i.e., wall)

o OPT Tilt - If a collector were tilted at the optimum tilt angle for each month this would be electricity production

o OPT ANG - This is the optimum tilt angle for each month of the year. 


\section{Solar Resource Characterization}

The solar resource data shows that a flat collector tilted at $32^{\circ}$ has an average yearly solar potential of $5.74 \mathrm{kWh}_{\text {solar }} / \mathrm{m}^{2} /$ day for White Sands Missile Range (see table E-1). A PV array set to the optimum angle each month will receive $6.07 \mathrm{kWh}_{\text {solar }} / \mathrm{m}^{2} /$ day incident solar radiation.

Table E-1: Monthly Averaged Radiation Incident On An Equator-Pointed Tilted Surface $\left(\mathrm{kWh} / \mathrm{m}^{2} /\right.$ day $)$

\begin{tabular}{|l|c|c|c|c|c|c|c|c|c|c|c|c|c|}
\hline & Jan & Feb & Mar & Apr & May & Jun & Jul & Aug & Sep & Oct & Nov & Dec & $\begin{array}{l}\text { Annual } \\
\text { Average }\end{array}$ \\
\cline { 2 - 14 } Tilt 0 & 3.01 & 3.7 & 4.86 & 5.96 & 6.48 & 6.68 & 6.15 & 5.52 & 4.87 & 4.08 & 3.26 & 2.68 & 4.78 \\
\hline Tilt 18 & 4.35 & 4.86 & 5.78 & 6.5 & 6.6 & 6.62 & 6.17 & 5.81 & 5.56 & 5.13 & 4.59 & 3.95 & 5.49 \\
\hline Tilt 32 & 5.17 & 5.51 & 6.16 & 6.53 & 6.28 & 6.14 & 5.8 & 5.68 & 5.78 & 5.68 & 5.39 & 4.75 & 5.74 \\
\hline Tilt 48 & 5.68 & 5.82 & 6.18 & 6.17 & 5.61 & 5.33 & 5.12 & 5.25 & 5.67 & 5.89 & 5.85 & 5.26 & 5.65 \\
\hline Tilt 90 & 5.18 & 4.81 & 4.34 & 3.45 & 2.54 & 2.22 & 2.28 & 2.77 & 3.73 & 4.65 & 5.18 & 4.9 & 3.83 \\
\hline OPT & 5.83 & 5.84 & 6.22 & 6.56 & 6.62 & 6.72 & 6.22 & 5.81 & 5.79 & 5.89 & 5.95 & 5.43 & 6.07 \\
\hline OPT ANG & 62 & 53 & 41 & 26 & 13 & 7 & 10 & 20 & 36 & 49 & 59 & 63 & 36.4 \\
\hline
\end{tabular}

Figure E-6 shows the incident solar radiation on a flat roof surface ( $0^{\circ}$ tilt), a fixed array (tilt=latitude), and a wall mounted system ( $90^{\circ}$ tilt).

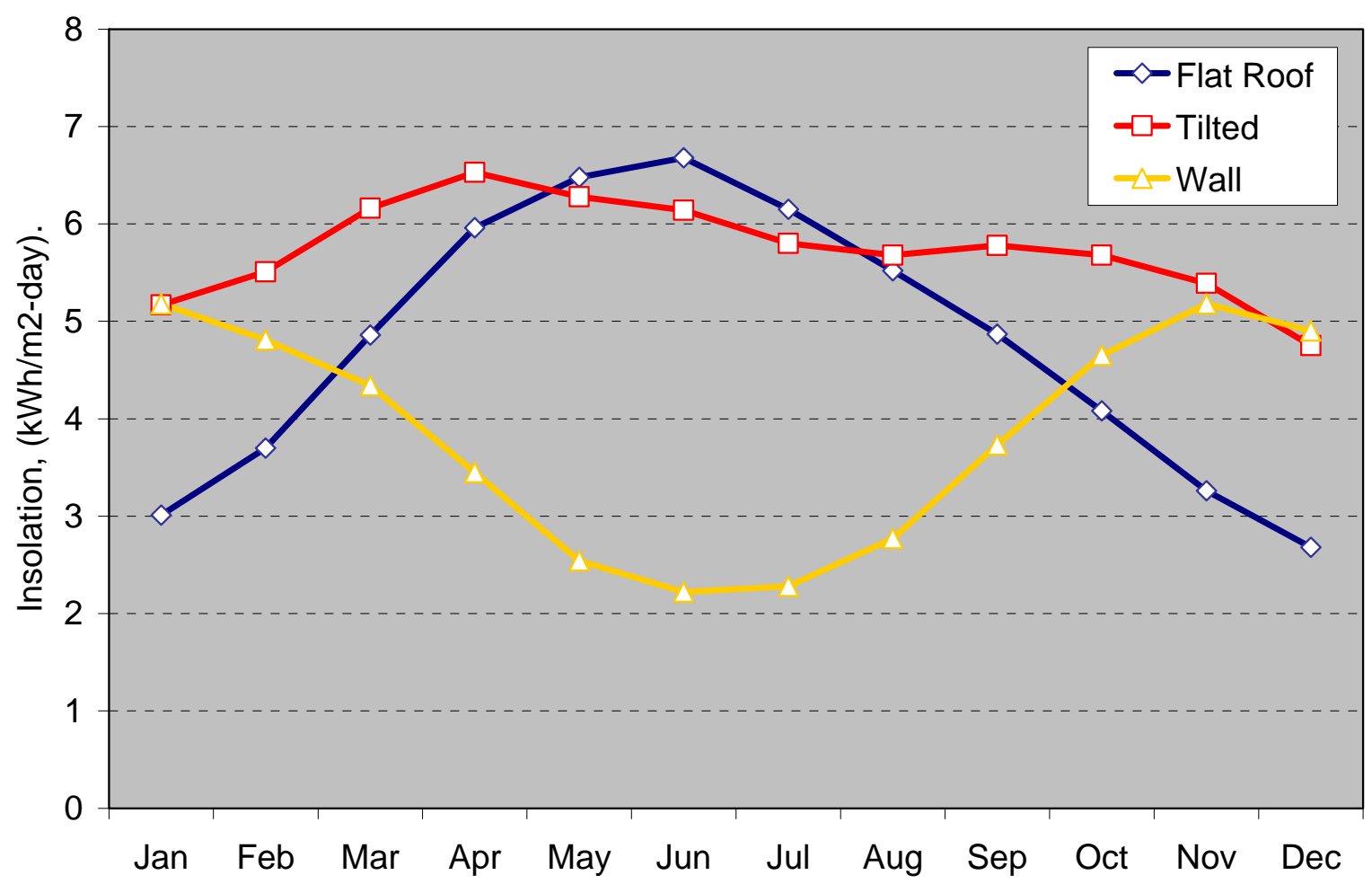

Figure E-6: White Sands Missile Range Average Daily Insolation 


\section{Findings: Solar Electric Production}

Based on the solar resource data, a flat collector tilted at an angle equal to the latitude $\left(32^{\circ}\right)$ has an average yearly solar potential of $5.74 \mathrm{kWh}_{\text {solar }} / \mathrm{m}^{2} /$ day. Solar conversion is an inefficient process, where typical PV cells have a conversion efficiency ranging from 10\% to 16\%. Whereas solar potential is expressed in $\mathrm{kWh}_{\text {solar }} / \mathrm{m}^{2}$, PV array production is generally express as annual energy produced per rated $1 \mathrm{~kW}$ of PV array. A typical 1-kW PV array might range in size from 8 to $9 \mathrm{~m}^{2}$. Taking into account the annual solar potential, the size of typical PV array, and the efficiency of a typical PV system, electric output would be expected to produce 1,832 $\mathrm{kWh}$ electric per $1 \mathrm{~kW}$ of installed PV capacity (see table E-2). The system would have a capacity factor of $20.9 \%$.

An axis-tracking PV array, which follows the sun's trajectory throughout the day, can produce $30 \%$ to $40 \%$ more energy than a stationary PV array and has a much flatter demand profile during the day. The tracking racks add to the cost of an installation by $\$ 1$ to $\$ 2$ per installed $\mathrm{kW}$. Because of this additional cost based on the size of array installed, tracking arrays will likely contain PV technologies with higher output per surface area in spite of the additional cost. An axis tracking array should produce $2,519 \mathrm{kWh}_{\text {electric }}$ annually per $1 \mathrm{~kW}$ of installed PV capacity. The system would have a capacity factor of $28.8 \%$.

Building-integrated solar products such as standing seam roofs and membrane embedded PV should be considered for new construction and major renovations where cost savings can be leveraged. For example, if a roof needs to be replaced, the replacement would be an avoided cost for the solar project. For example, a membrane-integrated PV product installed on a flat roof would be expected to produce $1,749 \mathrm{kWh}_{\text {electric }}$ annually per $1 \mathrm{~kW}$ of installed capacity. The system would have a capacity factor of $20.0 \%$.

Building integrated PV products are especially attractive if available land is constrained. WSMR appears to have available space for ground-mounted PV. However, satellite imagery shows that the 6 largest roofs on post have approximately 172,000 square feet of open roof area that could host PV. 0.5-MW of membrane-integrated PV could be installed, which would produce approximately 930 $\mathrm{MWh}_{\text {electric }}$ annually.

Table E-2: Solar Electric Production by PV Collector Type

\begin{tabular}{|c|c|c|c|c|}
\hline $\begin{array}{c}\text { Typical 1-kW PV } \\
\text { System }\end{array}$ & $\begin{array}{c}\text { Assumed PV } \\
\text { Module Efficiency }\end{array}$ & $\begin{array}{c}\text { Solar Insolation, } \\
\mathrm{kWh}_{(\text {solar })} / \mathrm{m}^{2} / \mathrm{yr}\end{array}$ & $\begin{array}{c}\text { Electric Production, } \\
\mathrm{kWh}_{(\text {electric })} / \mathrm{yr}\end{array}$ & $\begin{array}{c}\text { Capacity } \\
\text { Factor }\end{array}$ \\
\hline $\begin{array}{c}\text { South-Facing, } \\
\text { 32 }\end{array}$ & $11.0 \%$ & 2,035 & 1,832 & $20.9 \%$ \\
\hline Flat Roof & $7.6 \%$ & 1,944 & 1,749 & $20.0 \%$ \\
\hline 2-Axis Tracking & $11.0 \%$ & 2,799 & 2,519 & $28.8 \%$ \\
\hline
\end{tabular}




\section{Findings: Solar Project Economics}

Based on these numbers life-cycle costs were developed for solar technologies that would be implemented by White Sands Missile Range using federal funding such as ECIP. With the current average price of electricity at $4.2 \mathrm{c} / \mathrm{kWh}$, the fixed-grid PV had a 0.2 SIR and a 89 year simple payback. In fact, to get a positive net-present-value the system would have to charge $33.4 / \mathrm{kWh}$ for electricity produced. Even with carbon taxes and selling renewable energy credits, this would be hard to justify. The axis-tracking PV system did only slightly better (as a result of its better capacity factor) with a 0.2 SIR and a 74.7 year simple payback, producing $29.2 \$ / \mathrm{kWh}$ power. It is also important to consider that a very large PV project could also incur large exit or stand-by charges from the serving utility to continue to maintain capacity when the solar project is not producing.

A second mechanism to install solar projects would be to utilize a third party to develop the projects under a power purchase agreement (PPA) or other vehicle. Under a PPA, a private company would develop, fund, and install the solar project. The third party, being a private company, could take advantage of tax credits for renewable energy projects and might also wish to sell the "green tags" for this renewable energy. In addition if they were providing "firm" power to the installation as part of the contract, that would likely be obtained on the open market. When Fort Carson installed their 2-MW tracking PV array, one of the components of the funding package was that the private developer sold renewable energy credits (RECs) for $22 \mathrm{\$} / \mathrm{kWh}$. The market for RECs varies over time and by region, so it is not possible to know the exact value of RECs for solar PV at WSMR. However, if WSMR could find a private developer that could sell RECs at $22 \mathrm{c} / \mathrm{kWh}$, the project

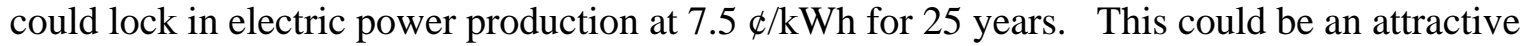
project for WSMR.

\section{Solar: Next Steps}

White Sands Missile Range has an abundant solar energy resource, although project capital costs and current electric rates are not showing these to be cost effective at this time. White Sands Missile Range should continue to monitor the market conditions affecting solar energy. Advances in PV technology are expected to produce cheaper solar cells, although rising demand may negate some of these advances. Rising energy rates may do the most to tip the scales in favor of solar electric. Probably the most important factor in making solar electric work at a federal installation is identifying key partners - either a private developer, a utility, or both - which can provide funding, capture tax incentives, purchase/market RECS, enter into PPAs, etc.

\section{Solar References}

NASA Surface Meteorology and Solar Energy (release 5.1) [http://eosweb.larc.nasa.gov/sse/].

RETscreen International, Clean Energy Decision Support Centre, CANMET Energy Technology Centre - Varennes, Natural Resources Canada. (c) Minister of Natural Resources Canada 1997 2005.

“Global Concentrating Solar Power Markets and Strategies, 2007-2020” Emerging Energy Research, LTD, Cambridge, MA, November 2007. 
TMY data from the Solar and Wind Energy Resource Assessment Programme, the International Weather for Energy Calculations (Version 1.1), 
APPENDIX F

Analysis of Wind Opportunities 
Renewable Energy Opportunities at White Sands Missile Range,

New Mexico

Pacific Northwest National Laboratory, Sept 2008 


\section{Appendix F: Analysis of Wind Opportunities}

\section{Wind Technology}

There is a vast wind resource in the United States. The American Wind Energy Association states that domestic wind resources, which are economically viable in at least 46 states, could theoretically supply all of the nation's electricity needs. At the current time, however, less than $1 \%$ of the nation's power is generated from wind. This situation is changing. In 2005 and 2006, wind was the second largest source of new electricity generation in the United States.

Wind projects, often referred to as wind farms, can be categorized by scale. Large, utility-scale projects tend to be $50 \mathrm{MW}$ and above, with the world largest single wind farm being the $735 \mathrm{MW}$ Horse Hollow Wind Energy Center in Texas. Smaller projects under $50 \mathrm{MW}$ are referred to as community wind projects or distributed generation (DG) projects. Community wind projects involve local ownership structures, often with corporate partners taking advantage of the Federal Production Tax Credit. DG projects are designed to offset the owner's retail electricity purchases by producing power that is used on site, with any surplus sold to a commercial utility.

Wind turbines come in many different sizes and configurations. Wind turbines in the U.S. generally employ the Danish configuration - a horizontal axis, three bladed rotor, an upwind orientation, and an active yaw system to keep the rotor oriented into the wind.

Utility-scale turbines for bulk power production tend to be $660 \mathrm{~kW}$ to $3 \mathrm{MW}$ in size. Hub heights can range from $50 \mathrm{~m}(164 \mathrm{ft})$ to $80 \mathrm{~m}(262 \mathrm{ft})$. Industrial turbines for consumer and remote grid production are found in the range of $50 \mathrm{~kW}$ to $250 \mathrm{~kW}$. Hub heights range between $25 \mathrm{~m}(80 \mathrm{ft})$ and $40 \mathrm{~m}$ (131 ft). Residential scale wind turbines are used for remote power, battery charging, or netmetering generation. These turbines tend to be 400 watts to $50 \mathrm{~kW}$. For turbines greater than $1 \mathrm{~kW}$, the hub heights range from $12 \mathrm{~ms}(40 \mathrm{ft})$ to $36 \mathrm{~m}(120 \mathrm{ft})$.

The land required for a single utility-scale wind turbine is typically 3 acres, including access roads, turbine base, and other equipment. A wind plant located on a ridgeline in hilly terrain will require less space than one on flat land, as little as 2 acres per MW. The proper spacing of turbines is essential to reduce wake interference and optimize the wind resource. In open flat terrain, a utilityscale wind plant will require about 60 acres per MW of installed capacity.

Although more difficult to finance and lacking in economies of scale, smaller wind generation projects (including potential projects at WSMR) offer some potential benefits over large-scale wind farms:

$\checkmark$ A smaller project is often easier to permit and may be less likely to interfere with other land uses (including military missions).

$\checkmark$ On-site power generation that is integrated into the site electrical system provides energy security.

$\checkmark \quad$ It may be possible to avoid building a costly substation if a suitably-sized power interconnection is located near a promising site for wind turbines. 
Wind Analysis Approach

\section{DoD Assessment Approach}

The DoD Renewables Study relied upon NREL wind potential maps to identify the installations with best potential for commercial-scale wind farms - considering both the wind resource and compatibility with the installation's mission. About 20 installations with potential for projects were selected for follow-on detailed assessments. WSMR was one of the 20 installations selected (GEC 2004).

As part of the detailed study, the DoD funded the installation of a meteorological (met) tower at selected sites for a 1-year wind resource assessment. Wind assessments were conducted by Global Energy Concepts (GEC) under a subcontract to NREL. Typically, GEC erected a met tower and collected data for 1 year. These data were analyzed with other information from a site visit to develop a sample wind turbine siting plan appropriate for the site and resource, as well as an estimate of developmental costs.

These data were then used for preliminary economic analyses under IPP and ECIP scenarios. In general, projects at least $20 \mathrm{MW}$ in size with a 30\% capacity factor, with at least a 15\% IRR were considered to be attractive to potential financers. Smaller projects, and those with IRRs between $10 \%$ and $15 \%$, were considered marginally financeable. Projects with payback periods less than 20 years and SIRs of at least 1.25 were considered to be eligible for ECIP funds (GEC 2004).

WSMR wind energy development areas identified in the initial DoD renewable assessment were located in the area between the cantonment, San Augustin Pass (to the northwest), and Owens Road (the north entrance road from Highway 70), as shown on Figure F-1 below. The development area encompasses approximately 1,430 acres. As a result of the complex wind flow on the east side of the mountains and through the pass, two met towers were proposed. One was located north of the end of Well Line Road and another on the east side of Owens Road. Wind resource measurements at WSMR were initiated in December 2003, providing 9 months of data from two 50-m met towers. The average wind speed measured at the site was only 4.4-4.5 m/s (9.8-10.0 mph). This wind resource is insufficient for large-scale wind energy development (GEC 2004). 


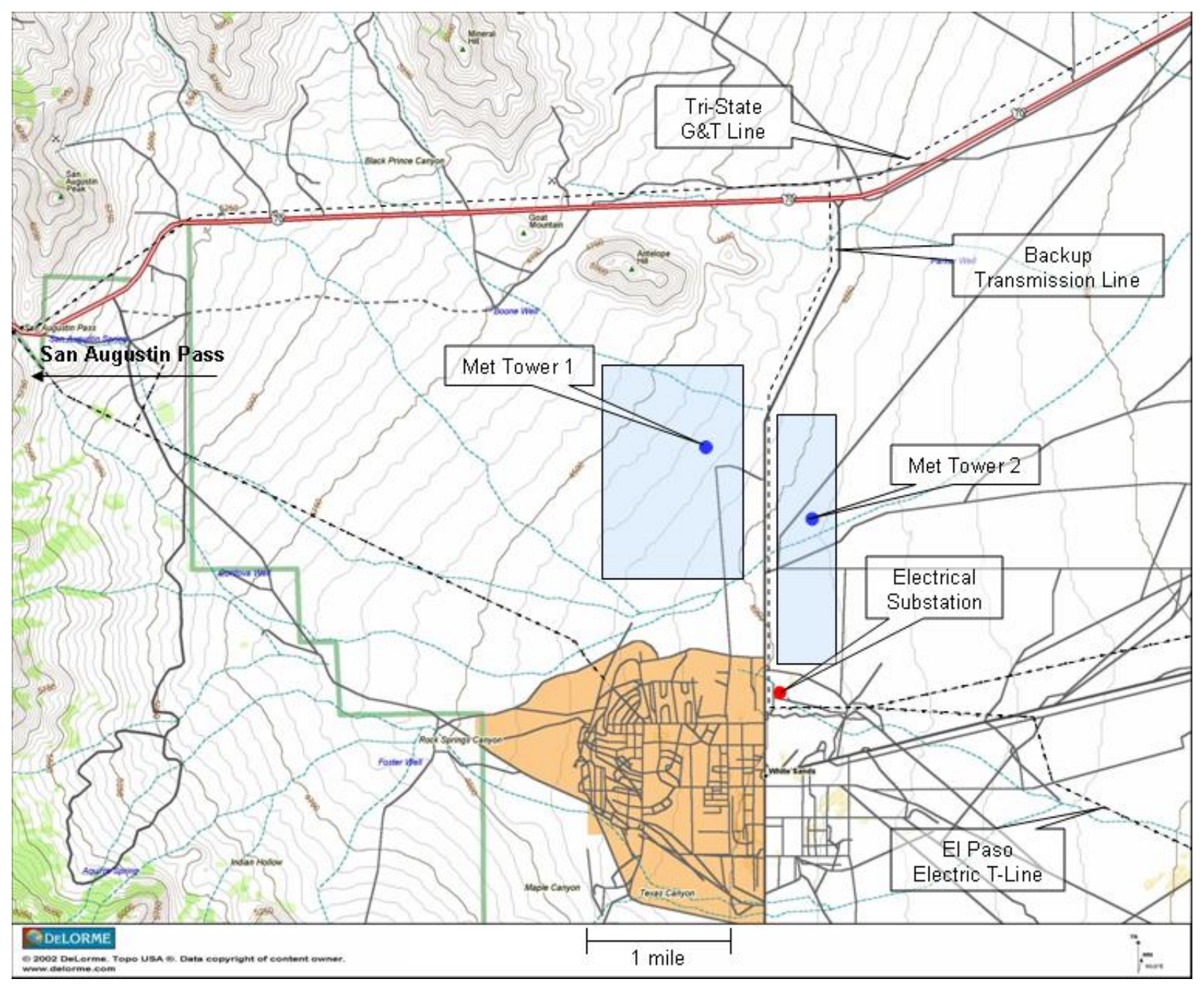

Figure F-1: Initial Location of Met Tower and Potential Wind Developments Area at WSMR (GEC 2004)

\section{Updated Wind Analysis Approach}

In this analysis, PNNL used the following approach to analyze the economic potential for wind energy at WSMR. More detail on the financing scenarios, generic analytic approach, and economic and other parameters used in this analysis are documented in Appendix A of this report.

(1) We relied upon new meteorological data (from the on-site met tower erected by New Mexico State University (NMSU) and updated wind maps (3Tier’s Firstlook wind maps).

(2) We evaluated the existing on-Post interconnection and transmission capacity and its available capacity.

(3) We surveyed local wind developer activity in the area to assess potential interest in developing projects. 
(4) We evaluated available turbine models to establish cost and performance parameters.

(5) We estimated total project cost, including project development, generation equipment, balance of plant construction, interconnection and transmission, operation and maintenance (O\&M), taxes, and tax credits and other policy incentives.

(6) We determined economic feasibility utilizing different financing scenarios: independent power producer ownership (IPP) and DoD ownership (ECIP).

(7) We determined project feasibility and recommended next steps.

\section{Wind Resource Characterization}

New data has emerged since the original wind resource assessment done by GEC several years ago. Upon further review of the available wind resource data, there appears to be available land on WSMR with the potential for high quality wind resource.

According to the NREL Wind Resource Map, WSMR has several Class 3 wind sites located along the western border of the installation and at the base of the San Andres Mountains (GEC 2004). The best wind resource is typically available in areas with increased elevation. Wind projects in New Mexico tend to occur in areas with winds of Class 4 or better.

NASA Langley Research Center Atmospheric Science Data Center was used to compare the average wind speed for the White Sands area. Using the Surface Meteorology and Solar Energy (SSE) provides data on a $1^{\circ}$ by $1^{\circ}$ grid system based on wind speed data over a 10 -year period from July 1983 to June 1993 meteorology. The annual average wind speed was found to be $5.2 \mathrm{~m} / \mathrm{s}$ at $50 \mathrm{~m}$ above the surface of the Earth. When projected up to 80 meters, the wind speed was $5.91 \mathrm{~m} / \mathrm{s}$. These results are much lower than other data sources, possible as a result of the wind data being drawn from such a large grid. NASA SSE data also provides the monthly averaged atmospheric Pressure (kPa) and the monthly averaged air temperature at $10 \mathrm{~m}$ about the surface of the Earth. This temperature and pressure data was utilized for calculating the capacity factor for wind at WSMR (NASA 2008).

New Mexico State University has been working with NASA White Sands Test Facility on a Wind Feasibility Study. Two sites were identified and meteorological towers were erected. One site is located on the Quartzite Mountain Range east of the test facility in Doña Ana County. The initial feasibility study predicted that the Quartzite Mountain site would be rated as a low Class 5 wind site with an average annual windspeed of $7.8 \mathrm{~m} / \mathrm{s}$ at $50 \mathrm{~m}$. This site is estimated to be able to support 14, 1.5-MW turbines. Access to this site is very difficult; a new road would need to be constructed to develop a wind farm at this location (estimated cost is $\$ 1.4$ million for a 3.88 mile road). The secondary site is located on Saddle Mountain, but only class 3 winds $(6.6 \mathrm{~m} / \mathrm{s}$ at $50 \mathrm{~m})$ were predicted with room for 2 to 3 turbines. Access to this site is significantly easier (Foster 2004). Actual wind results from met tower located at the Quartzite Mt. site were reported to be $7.0 \mathrm{~m} / \mathrm{s}$ at 40 m (personal communication with Robert Foster, 2008).

Another source of wind speed potential was consulted, the Firstlook wind mapping tool from 3TIER. At the Quartzite Mt. site, the highest wind speed found was only $6.0 \mathrm{~m} / \mathrm{s}$ at $50 \mathrm{~m}$. The met tower data has indicated that this site actually has higher winds. The highest wind speeds found on the 
installation, as indicated by Firstlook, were located in the far northeast corner of the installation. See Figure F-2 below. The light gray area indicates the boundary of the installation. At this location, at $50 \mathrm{~m}$ height above ground, the potential average annual wind speed is estimated to reach $7.2 \mathrm{~m} / \mathrm{s}$, or $7.8 \mathrm{~m} / \mathrm{s}$ at $80 \mathrm{~m}$ height (3TIER 2008).

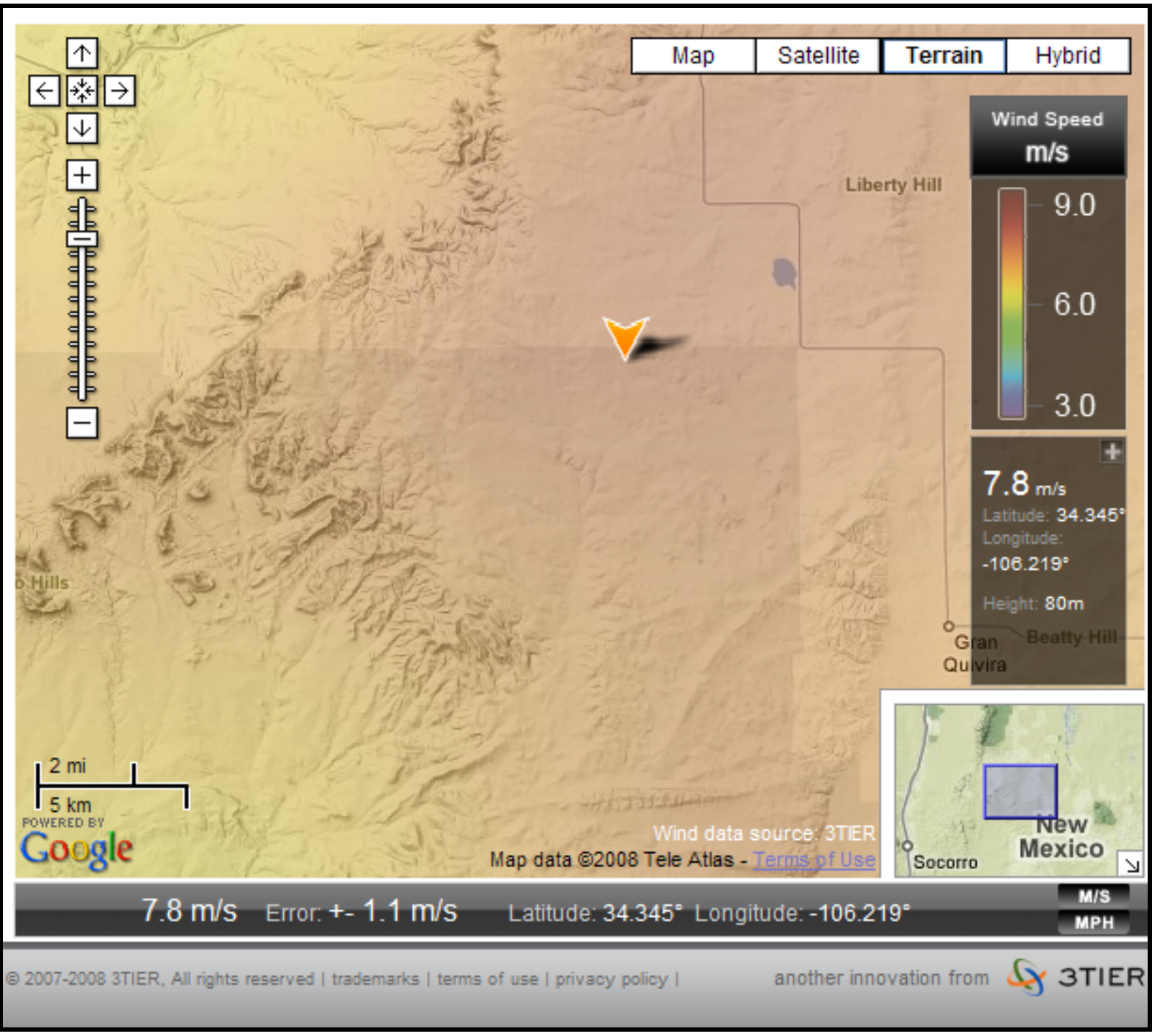

Figure F-2: Location of highest wind at WSMR as indicated by 3TIER's Firstlook mapping tool

To achieve the most accurate predication of the wind potential, a met tower is the best source for data. For this analysis, the measured wind speed of $7.0 \mathrm{~m} / \mathrm{s}$ at $40 \mathrm{~m}$ height from the Quartzite Mt. site was utilized. When projected up to $85-\mathrm{m}$ height, the result is $7.8 \mathrm{~m} / \mathrm{s}$, the same wind speed found in the NE corner of the installation by Firstlook at 80-m height. 


\section{Additional Siting Considerations}

One siting consideration for wind projects is transmission availability and capacity. Projects need to be located within close proximity of existing transmission lines, or new lines will need to be constructed at considerable cost. There is a 69.- $\mathrm{kV}$ line located 2.5 miles from the met tower site (Foster 2004). This could be a connection point if a small scale project was installed (potentially 21 MW), as long as there is capacity on the line.

Another consideration that could affect the viability of wind generation at WSMR is potential interference with airport operations. The FAA requires notice of proposed construction for a project so that it can determine if there would be adverse impacts to air navigation safety. One of the triggering criteria is whether the project would be located within 20,000 feet (6,096 m) or less of an existing public or military airport. El Paso International Airport and Biggs Army Airfield are located over 60 miles away from the identified wind development area at WSMR. If the development area remains the same, neither airport should trigger notification to the FAA based on distance. Another FAA criterion triggering the notice of proposed construction is any construction or alteration of more than $200 \mathrm{ft}(61 \mathrm{~m})$ in height above ground level. This criterion applies regardless of the distance from the proposed project to an airport. A determination of No Hazard to Air Navigation must be obtained from the FAA prior to constructing a wind project.

Until a wind farm construction engineer visits the site, and an interconnection and transmission analysis is performed, questions remain about the constructability and transmission access for the potential sites

\section{Wind: Economic and Other Analysis Parameters}

This assessment considered the current federal wind incentive - $\mathrm{a} 2.0 \$ / \mathrm{kWh}$ renewable energy production credit and 5-year accelerated depreciation. New Mexico incentives for wind include a renewable energy tax production tax credit, a sales tax exemption and a renewable energy portfolio standard (RPS) (DSIRE 2007).

The renewable energy tax credit is capped at 400,000 MWh annually for wind, but with an installation of $21 \mathrm{MW}$ (with a 35\% capacity factor) the project production should stay below this limit. There is an annual cap of 2,000,000 MWh for the state, so one needs to carefully consider whether there is any production tax credit capacity available before committing to a project that requires the production tax credit to be included in order to be feasible. The production tax credit applies up to the cap at $1 \mathrm{\Phi} / \mathrm{kWh}$ for wind.

For the sales tax exemption, we are assuming that the assembly of the renewable energy system would meet the exemption requirements. This assumption would need to be checked carefully with the State of New Mexico. There is also a possibility that a wind project could benefit from the sale of renewable energy credits (RECs) to utilities needing to meet New Mexico's Renewable Portfolio Standard requirements.

During the original DoD renewable energy assessment in 2004, the installed cost of capital was approximately $\$ 1,400 / \mathrm{kW}$; at the current time prices range from $\$ 1,700$ to $\$ 2,600 / \mathrm{kW}$ because of a world-wide turbine shortage and increased costs for components. The capital cost was assumed to be 
$\$ 1,841.20$ per $\mathrm{kW}$ (including incentives) for this economic assessment. Fixed O\&M cost was assumed to be $\$ 20 / \mathrm{kW}$.

For this assessment, a wind farm size of 21 MW was assumed based upon the land availability on the Quartzite Mt. site described in the NASA JSC White Sands Test Facility feasibility assessment (Foster 2004). If a larger project is desired, WSMR could explore the wind potential, interconnection potential, and electrical delivery potential of the site in the far NE corner of the installation.

When the economic calculations were run for this assessment, a capacity factor of 35\% was utilized. This is based upon the average wind speed of $7.0 \mathrm{~m} / \mathrm{s}$ at 40 meters from the on-site met tower. When calculated up to $85-\mathrm{m}$ height, the resulting wind speed is $7.8 \mathrm{~m} / \mathrm{s}$. Assuming a 1.5-MW wind turbine with a $77-\mathrm{m}$ rotor diameter, the $7.8 \mathrm{~m} / \mathrm{s}$ wind speed would results in a capacity factor of $35 \%$. This wind speed is very close to the wind speed found in the NE corner of the installation from the First Look wind map from 3TIER (7.8 m/s at $80-\mathrm{m}$ height). The economic findings would therefore be very similar for this location. But the potential wind speed would need to be confirmed with a met tower, and the interconnection and transmission availability would need to be evaluated.

The analysis assumed that the $69-\mathrm{kV}$ transmission lines located 2.5 miles from the met tower location in the Quartzite Mountains would be available to transmit power without substantial additional investment.

For the economic evaluation of the wind resource potential, the energy component of $4.2 \$ / \mathrm{kWh}$ was used for as the avoided rate for wind. The average rate paid by WSMR is assumed to be $7.4 \mathrm{c} / \mathrm{kWh}$, but because of the intermittent nature of wind, only the energy component $4.2 \mathrm{c} / \mathrm{kWh}$ was utilized in the economic evaluation. Further details on the analysis methodology and the economic and incentive parameters are documented in Appendix A of this report.

Table F-1: Performance, Cost, and Economic Characteristics

\begin{tabular}{|c|c|}
\hline Assumed wind speeds & $7.8 \mathrm{~m} / \mathrm{s}$ at $85 \mathrm{~m}$ height \\
\hline Capacity Factor (using $1.5 \mathrm{MW}$ wind turbine) & $35 \%$ \\
\hline Project Size & $21 \mathrm{MW}$ \\
\hline Estimated Annual Energy Production & $64,577 \mathrm{MWh}$ \\
\hline Avoided Cost of Energy & 4.2 \$/kWh \\
\hline Total Capital Cost & $\$ 1,841 / \mathrm{kW}$ \\
\hline
\end{tabular}

\section{Findings: Wind}

Wind generation shows some promise for WSMR. Using the existing met tower data, the project should produce power at a price of approximately $6.1 \mathrm{\$} / \mathrm{kWh}$. The cost of wind production is slightly higher than the avoided cost for power that is currently being provided by El Paso Electric (6.1 $\$ / \mathrm{kWh}$ versus $4.2 \$ / \mathrm{kWh})$.

Utilizing the met tower calculated wind speed of $7.8 \mathrm{~m} / \mathrm{s}$, a commercial energy cost of $6.1 \mathrm{\$} / \mathrm{kWh}$ would be required to provide a 10\% IRR (the minimum IRR required to attract wind developer interest). Compared to the avoided energy rate of $4.2 \mathrm{\$} / \mathrm{kWh}$, the IRR is only $6.02 \%$. ECIP projects require an SIR of 1.0 for renewable energy. When using $4.2 / \mathrm{kWh}$, the SIR is 0.7 and the simple payback is 19.6 years. This project would not qualify for ECIP funding. 
Note that these analyses assumed that an on-site wind project would not trigger new stand-by or other fees from the local utility. If it is necessary to wheel power from the wind project location to the cantonment over utility transmission lines, transmission costs could be incurred. This charge could be very high. Because wind is intermittent, power from a wind farm would need to be blended with power from other sources to ensure reliable power to the base. This may complicate power procurement compared to a purchase from a conventional supplier. If a wind project is pursued further, the potential impact of transmission charges and other utility and marketing fees must be included in the economic analysis. These analyses did not increase the capital costs for installation because of the road that would need to be constructed to build this wind farm. The NMSU wind feasibility study estimated road costs of \$1.4 million for a 3.88 mile road in 2004.

Also, these calculations do not include the potential sale of renewable energy certificates (RECs), which could further increase the value of the wind energy produced. If RECs could be sold at a rate of $1.9 \$ / \mathrm{kWh}$, this project would compete with the avoided cost of energy at WSMR.

\section{Wind: Next Steps}

It makes economic sense to further investigate and pursue a wind generation project on post at this time because the current cost of commercial power is close to costs from a wind generation project. One important characteristic of wind power is that its cost is not dependent upon the cost of fossil fuels. Because the cost of fossil-generated energy is expected to increase on a continuing basis, it may be possible to negotiate a fixed-price long-term (20-year) supply contract for wind energy now that will save considerable money over the term of the contract.

To verify the wind resource, the data collection from the existing met tower should be continued. A wind project development expert should be consulted and conduct a site visit to determine constructability of site and potential locations for wind turbines. An interconnection and transmission analysis is needed to determine how many MW of wind capacity could be connected

and delivered to the installation. A meteorological expert should be consulted to review and confirm the wind data results.

As another alternative, White Sands may want to consider joining with the neighboring installation of Ft. Bliss to pursue a project that would meet the needs of both installations. Ft. Bliss has been evaluating the option of developing a wind farm within their installation boundary. They have identified a potential development site and erected a met tower. After 1 year of data gathering, the average annual wind speed was found to be $6.8 \mathrm{~m} / \mathrm{s}$ at $50 \mathrm{~m}$ height (NMSU 2008). There is seems to be sufficient land and transmission available for a large project $(100+\mathrm{MW})$. The size of the transmission line located close to the site $(345 \mathrm{kV})$ would make more economic sense for interconnection if the project were larger because it is expensive to build a substation to connect the wind project to such a large line. To utilize the full output of a large wind farm, Ft. Bliss would need to partner with additional off takers for the energy. A partnership between the installations to pursue a joint wind project may make economic sense.

\section{Wind References}

3TIER Environmental Forecast Group, Inc., 2008. “Firstlook Wind Assessment Map.” http://firstlook.3tiergroup.com/wind 
American Wind Energy Association. 2007. "Wind Power Today." http://www.awea.org/pubs/factsheets/WindPowerToday_2007.pdf

DSIRE 2007c. "New Mexico Incentives for Renewable Energy.” http://www.dsireusa.org/library/includes/map2.cfm?CurrentPageID=1\&State=NM\&RE=1\&EE=1. Date visited 6/13/2008

Federal Aviation Administration. 2007. Advisory Circular (AC 70/7460-1K) Obstruction Marking and Lighting. Effective: February 2, 2007.

http://www.airweb.faa.gov/Regulatory_and_Guidance_Library/rgAdvisoryCircular.nsf/0/b993dcdfc3 7fcdc486257251005c4e21/\$FILE/AC70 7460 1K.pdf

Fischer, Holger. 2006. "White Sands Test Facility: Alternative Energy Generation to Support Groundwater Remediation.” Presentation made at NASA International Workshop on Pollution Prevention and Sustainable Development. Colorado Springs, CO. November 2006.

http://acqp2.nasa.gov/workshop2006/Presentations\%202006/Fischer\%20WSTF\%20Renewable\%20E nergy\%20Final.pdf

Foster, Robert. Ken Starcher, and Luis Estrada. 2004. "Utility Interconnected Wind System Preliminary Feasibility Study. NASA JSC White Sands Test Facility.” June 2004. Southwest Technology Development Institute, College of engineering, New Mexico State University.

Global Energy Concepts, LLC. 2004. "U.S. Department of Defense Renewable Energy Assessment: Report of Wind Energy Potential On and Near Military Installations.” Prepared for NREL Subcontract No: LAM-3-32257-01

NASA Langley Research Center. 2008. Atmospheric Science Data Center. Last Updated March 26, 2008. http://eosweb.larc.nasa.gov/sse/.

New Mexico State University (NMSU). 2008. "Wind Monitoring Project Yearly Performance Report June 07 - June 08.” Prepared for: MC Fuhrman and Associates, LLC and URS, Inc. for Ft. Bliss under contract to The US Army Corps of Engineers. June 2008. 
F-10

Renewable Energy Opportunities at White Sands Missile Range New Mexico

Pacific Northwest National Laboratory, Sept 2008 


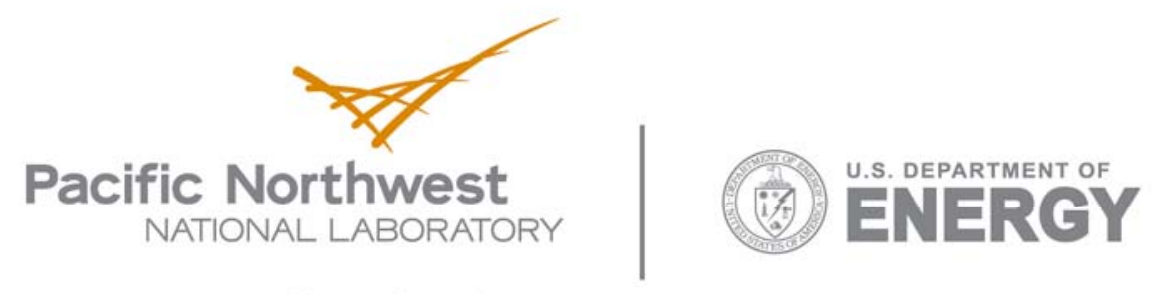

902 Battelle Boulevard

P.O. Box 999

Richland, WA 99352

1-888-375-PNNL (7665)

www.pnl.gov 